\title{
2. PLANKTONIC FORAMINIFER BIOSTRATIGRAPHY AND THE DEVELOPMENT OF PELAGIC CAPS ON GUYOTS IN THE MARSHALL ISLANDS GROUP ${ }^{1}$
}

\author{
Paul N. Pearson ${ }^{2}$
}

\begin{abstract}
Five guyots were drilled on Ocean Drilling Program Leg 144, three of which possess thick caps of pelagic sediment. These guyots (Limalok, Site 871; Lo-En, Site 872; and Wodejebato, Site 873) belong to the Marshall Islands group of seamounts. Pelagic sediments of late Oligocene to Holocene age were recovered from them. In each case, the sediment was found to be unconsolidated on recovery and contain very abundant planktonic foraminifers, particularly in the $>150-\mu \mathrm{m}$ size range. Preservation of tests is generally good, with most showing only minor signs of dissolution or recrystallization, although many samples have a high proportion of fragmented material in the fine fraction.

Planktonic foraminifer faunas are diverse and consist predominantly of warm-water species. A typically western Pacific fauna occurs throughout the Miocene. Biostratigraphic assignment was generally straightforward except for the bottommost interval of the pelagic caps where severe reworking (sediment mixing) is a common feature. A significant hiatus was found at each site between drowning of the carbonate platform and the onset of pelagic sediment accumulation. Thus, the platforms were apparently swept clean of sediments, with the exception of isolated ponds, until subsidence took the guyots sufficiently deep for sediment to accumulate in large quantities. Backtracking of subsidence paths for each guyot suggests that pelagic cap formation began at depths of between 700 and 1000 mbsl. The first phase of pelagic cap formation was accompanied by significant transport and mixing of sediment. Eventually, with further subsidence, more continuous and less disturbed sequences were deposited.

Several hiatuses occur at various levels within the pelagic caps, the durations of which range from more than 5 m.y. down to the limit of biostratigraphic resolution. These probably relate to changes in the local hydrographic regimes because there is little similarity in the timing of hiatuses between the guyots.
\end{abstract}

\section{INTRODUCTION}

The abyssal seafloor in much of the west Pacific Ocean is too deep for carbonate sediment to be preserved. The sporadically distributed accumulations of pelagic sediment atop drowned seamounts (guyots) provide the best opportunity for recovering well-preserved carbonate oozes from the region. During Ocean Drilling Program (ODP) Leg 144, the thick pelagic caps of three guyots in the Marshall Islands group of seamounts were drilled. The planktonic foraminifer biostratigraphy of these sequences and the sedimentological deductions that can be made from the planktonic foraminifer biostratigraphy are the subjects of this paper. The guyots are Limalok (previously known as "Harrie" Guyot; Site 871), Lo-En (Site 872), and Wodejebato (previously known as "Sylvania" Guyot; Site 873). The location of these sites in relation to other local atolls and seamounts is shown in Figure 1.

Pelagic sediment may begin to accumulate on a guyot in significant quantities only after drowning of the carbonate platform (if present) and subsidence. The amount of sediment retained by the guyot is then dependent both on its topography and the local hydrographic conditions. Paleoceanographic change or subsidence may cause changes in local conditions on the seafloor and be reflected in the sediment record as changes in the accumulation rate or by an unconformity. An objective of Leg 144 was to assess the suitability of the sections for paleoceanographic studies and investigate whether any patterns can be discerned in the timing and style of sediment accumulation on the guyots drilled.

The study of planktonic foraminifers (which, in each of the three guyots studied, constitute the bulk of the pelagic sediment at most levels) provides a tool for examining these questions. For the most part, biostratigraphic age assignment was straightforward. However,

\footnotetext{
'Haggerty, J.A., Premoli Silva, I., Rack, F., and McNutt, M.K. (Eds.), 1995. Proc. ODP. Sci. Results, 144: College Station, TX (Ocean Drilling Program).

${ }^{2}$ Department of Earth Sciences, University of Cambridge, Downing Street, Cambridge, CB2 3EQ. United Kingdom. (Present address: Department of Geology. University of Bristol, Queens Road, Bristol BS8 IRJ, United Kingdom.)
}

observed accumulation rates were generally low at all three sites and hiatuses are common. This was an expected feature because the pelagic caps thin toward their edges and thus have the appearance of being affected by winnowing, erosion, and sediment export. A more unexpected feature was severe reworking, which was encountered at various levels in the three sites. Reworking was unexpected because in each case a fairly central location on the guyot was chosen for drilling. Thus, significant inward transport of sediment from the fringes of the edifice toward the center is implied. By using planktonic foraminifer species as age-diagnostic markers, it was possible to reconstruct the reworking histories on the three guyots.

\section{METHODS}

The pelagic caps of Limalok (Site 871), Lo-En (Site 872), and Wodejebato (Site 873) guyots were all recovered using the advanced hydraulic piston corer (APC). For two of the guyots (Limalok and Lo-En), two adjacent holes were drilled. High-resolution stratigraphy and correlation between the holes at these sites has not been attempted because the sediment in each case was observed to be extremely unconsolidated and well mixed in the core barrel during recovery. Consequently, at Sites 871 and 872 , the most detailed biostratigraphy in each case was attempted on the hole with the most complete recovery, with the second hole used to provide supporting evidence.

In general, one sample per section was studied, except in cases of condensed sequences, for which two samples per section were analyzed. Core-catcher samples were also studied. The sampling density allowed most planktonic foraminifer datums to be constrained to within $1.5 \mathrm{~m}$ of core. Sediment volumes of about $10 \mathrm{~cm}^{3}$ were taken, which typically yielded very large numbers of planktonic foraminifers, owing to their extreme abundance. All samples were sufficiently unconsolidated to break down in water. They were washed over 150and $40-\mu \mathrm{m}$ sieves, and the residues were dried on a hot plate at $50^{\circ} \mathrm{C}$. The following abundance categories were estimated for each species in each sample by a visual examination of the $>150-\mu \mathrm{m}$ size fraction: $\mathrm{A}=$ abundant $(>30 \%), \mathrm{C}=$ common $(15 \%-30 \%), \mathrm{F}=$ few $(3 \%-15 \%)$ 


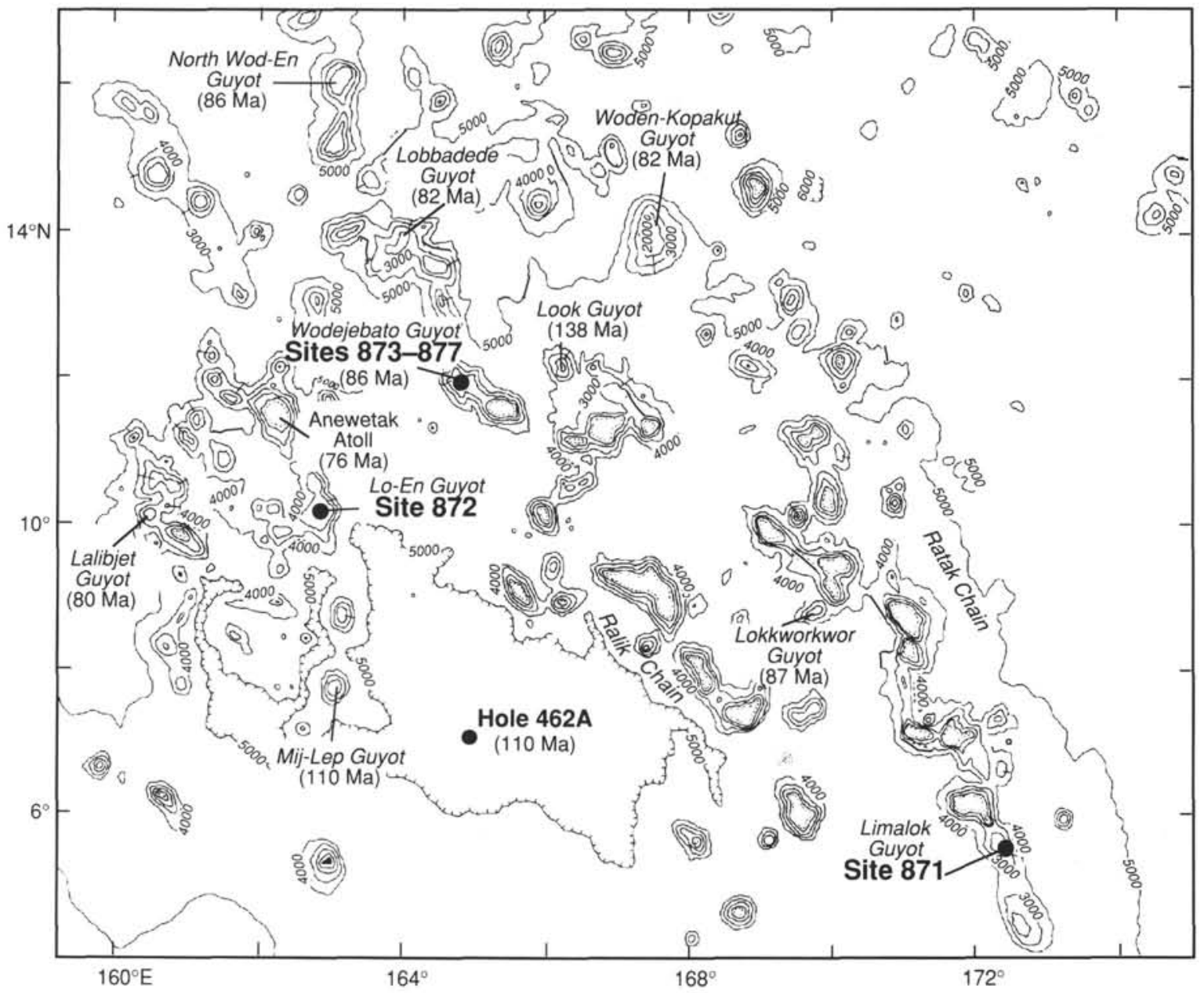

Figure 1. Bathymetry of the Marshall Islands region. The locations of the three guyots studied are indicated. Contour interval is $1000 \mathrm{~m}$. Radiometric ages shown in parentheses are from Davis et al. (1989) and Pringle (1992). Figure revised from Hein et al. (1990).

and $\mathrm{R}=$ rare $(<3 \%)$. Small species marked rare may actually be abundant in the 40 - to $150-\mu \mathrm{m}$ fraction.

Because reworking was very common, and because it is not always possible to distinguish reworked from in situ specimens, no attempt was made to distinguish the two categories on the range charts. Similarly, no attempt was made to indicate in the tables which occurrences are thought to be downhole contaminants. The extent of reworking and downhole contamination in each sample was estimated on the following scale: $1=$ light, 2 = moderate, and $3=$ severe. No attempt was made to quantify these estimates because of the many unknown factors that exist in deciding the percentage of reworked individuals or contaminants to sediment in situ.

Preservation was studied visually and, for some samples, by scanning electron microscope (SEM) (see plates). Evidence of dissolution and recrystallization is minor, even toward the bases of the pelagic caps. However, mechanical breakage and fragmentation were commonly observed. The extent of fragmentation was estimated for each sample based on a visual examination of the fine $(40-150 \mu \mathrm{m})$ size fraction. To ensure consistency, samples from all levels at all sites were examined "blind" and in random order. The following qualitative scale was used: $1=$ light $(<20 \%$ fragmented material $), 2=$ moderate $(20 \%-$ $50 \%), 3=$ severe $(50 \%-80 \%)$, and $4=$ very severe $(>80 \%)$. The percentage of broken tests is always lower in the coarse fraction.

Benthic foraminifers in these sediments are extremely scarce in comparison with other intermediate depth sites, and no samples contain a full fauna (A. Boersma, pers. comm., 1994). In general, only small benthic species are present except for some large agglutinated forms in some samples. The very low abundance and diversity of the benthic foraminifer faunas apparently indicates an unusually disadvantageous environment. This could be the result of a lack of food, or it could possibly reflect the influence of strong bottom currents. Benthic foraminifers were not studied in detail.

\section{BIOSTRATIGRAPHIC ZONATION}

The tropical zonal scheme of Kennett and Srinivasan (1983) for the Neogene is used, with some modifications, which are discussed below. The zonation of Berggren and Miller (1988) is used for the upper Oligocene. Figure 2 shows the relationship between the biostratigraphy used in this study to other commonly used zonations. Also shown is a list of the datums that were used on the time scales of Berggren et al. (1985a, 1985b).

Severe reworking ("sediment mixing") occurs in certain intervals of each pelagic cap. In such cases, the quoted age of the sample is always given as the age of its youngest component (except for downhole contamination), even when it appears that the majority of the sediment is reworked. The apparent stratigraphic "age inversion" occasionally noted was probably the result of large-scale reworking of packets of sediment. In these cases, the age of a sample is considered to be the age of the youngest component found stratigraphically below it.

Even in the well-used Neogene planktonic foraminifer zonation there are several points of difference between workers. The zonal definitions used in this study are discussed below. 


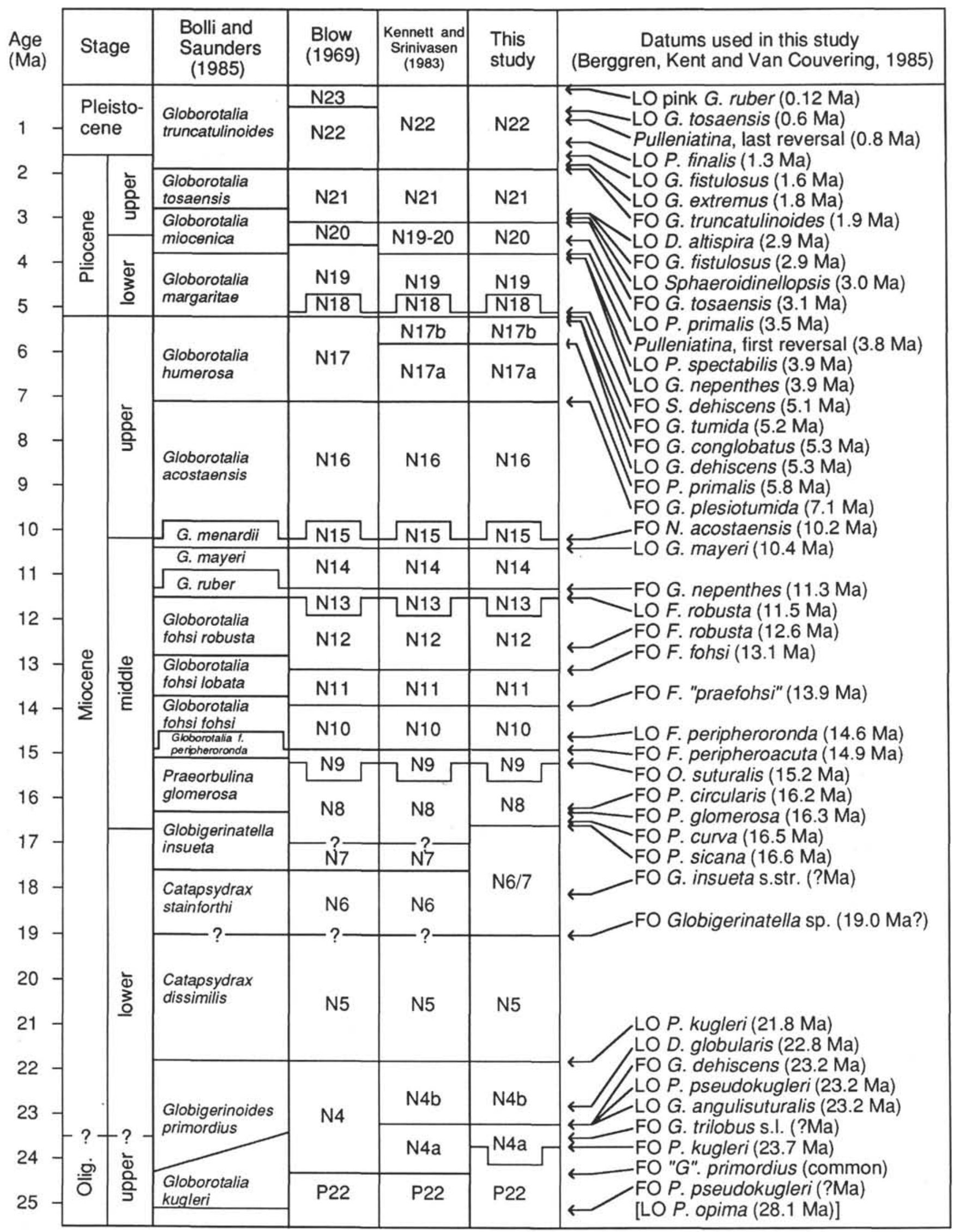

Figure 2. Zonal scheme and list of biostratigraphic datums used in this study, in comparison with standard tropical zonations for planktonic foraminifers. 


\section{Zone P22}

Definition. Interval from the last occurrence (LO) of Paragloborotalia opima (base) to the first occurrence (FO) of Paragloborotalia kugleri (top).

Discussion. Zone P22 was found at the bottom of Hole 872C. The base of Zone P22 is ideally recognized by the LO of Paragloborotalia opima. This species is differentiated from Paragloborotalia nana on the basis of size alone (Bolli and Saunders, 1985). At the bottom of the pelagic cap at Site 872, P. opima occurs with other elements that are probably derived from Zone P21 and lower (e.g., Subbotina gortanii, Chiloguembelina cubensis, and Pseudohastigerina micra). However, these are interpreted as reworked individuals because they occur in association with younger elements.

The presence of Paragloborotalia pseudokugleri, even in the lowest samples, is utilized for recognizing that the lowest sediments belong to Zone P22. According to Berggren and Miller (1988), P. pseudokugleri first appears in the middle portion of Zone P22. In other sites in the western Pacific region (such as at Sites 292,296, and 803), the FO of $P$. pseudokugleri (recorded as "P. kugleri sensu lato") is at about the same level (Ujiie, 1975). However, Premoli Silva and Spezzaferri (1990) and Spezzaferri and Premoli Silva (1991) found the first appearance of $P$. pseudokugleri at intervals near the base of Zone P22 in the Indian Ocean and Gulf of Mexico. No authors have found this species in Zone P21 or older.

Another species characteristic of Zone P22 and younger is "Globigerinoides" primordius. Berggren and Miller (1988) documented the FO of this taxon in mid-Zone P22, a little higher (by 0.5 m.y.) than the FO of $P$. pseudokugleri. Other Pacific studies accord with this. However, Premoli Silva and Spezzaferri (1990) and Spezzaferri and Premoli Silva (1991) recorded contemporaneous FOs for " $G$." primordius and $P$. pseudokugleri near the bottom of Zone P22 in the Indian Ocean and Gulf of Mexico, whereas Leckie et al. (1993) record the FO of "G." primordius near the base of Zone P22 in the western North Atlantic. At Site 872, "Globigerinoides" primordius occurs with P. pseudokugleri at the bottom of the pelagic cap.

\section{Zone N4}

Definition. Total range of Paragloborotalia kugleri s.str.

Discussion. The first appearance of Globigerinoides was used by Blow (1969) and Kennett and Srinivasan (1983) to denote the base of Zone N4. However, "Globigerinoides" primordius has been recorded by various authors at lower levels (e.g., Berggren and Miller, 1988; Leckie et al., 1993). Consequently, the first appearance of Paragloborotalia kugleri $\mathrm{s}$.str. is used as the basal marker following Berggren and Miller (1988) and subsequent authors.

\section{Subzone N4a}

Definition. Interval from the FO of Paragloborotalia kugleri to the FO of Globoquadrina dehiscens.

Discussion. Kennett and Srinivasan (1983) used the first appearance datum of Globoquadrina dehiscens to subdivide Zone N4 and suggested that this level approximates to the Oligocene/Miocene boundary. Globoquadrina dehiscens is distinguished from its ancestral form Globoquadrina praedehiscens by having four chambers in the final whorl (see taxonomic discussion).

Premoli Silva and Spezzaferri (1990) recorded a low FO of $G$. dehiscens at Indian Ocean Leg 115 sites in late Oligocene Zone P22. Thus, the appearance of the dehiscens morphotype appears to be strongly diachronous between ocean basins. Consequently, they used the "diversification level of Globigerinoides" to mark their Subzone $\mathrm{N} 4 \mathrm{a} / \mathrm{N} 4 \mathrm{~b}$ boundary, which they approximate to the Oligocene/Miocene boundary. (Note that this level lies within Subzone N4a as used here.) Exactly which datum is closest to the Oligocene/Miocene boundary awaits a biostratigraphic review and the selection of a boundary stratotype.
In Site 872, the first appearance of G. dehiscens is above the level of the first appearance of Paragloborotalia kugleri and consequently can be used to recognize the Subzone N4a/N4b boundary. The first appearance of $G$. dehiscens appears to be useful for correlation within the Pacific at least (see Srinivasan and Kennett, 1983; Keller, 1980; Chaisson and Leckie, 1993; Leckie et al., 1993).

\section{Subzone N4b}

Definition. Interval from the FO of Globoquadrina dehiscens to the LO of Paragloborotalia kugleri.

Discussion. See discussion of Subzone N4a.

\section{Zone N5}

Amended definition. Interval from the LO of Paragloborotalia kugleri to the FO of Globigerinatella sp.

Discussion. The recognition of the base of Zone N5 is straightforward at Site 872, but at Site 871 Paragloborotalia kugleri is found in association with Globigerinatella sp. P. kugleri is also found at higher levels. These specimens are interpreted as reworked.

\section{Zone N6/N7 Undifferentiated}

Amended definition. Interval from the FO of Globigerinatella sp. to the FO of Praeorbulina sicana.

Discussion. The biostratigraphic value of Globigerinatella was recognized by Cushman and Stainforth (1945) and has been used to denote the base of Zone N6 in standard zonations (e.g., Kennett and Srinivasan, 1983). The genus has usually been regarded as monospecific. However, in this study two species of Globigerinatella are recognized: $G$. insueta s.str. and Globigerinatella sp. The base of Zone N6 is recognized by the first appearance of Globigerinatella sp. However, it remains to be investigated whether this level correlates well with the first appearance of Globigerinatella insueta in other areas.

The LO of Catapsydrax dissimilis has been used to identify the base of Zone N7 (Kennett and Srinivasan, 1983). However, this species is rare in Leg 144 sediments. In Hole $871 \mathrm{~A}$, the LO is in Sample 144-871A-10H-4, 59-61 cm. A correlation based on this was not attempted because this level is affected by reworking and some apparently younger elements (e.g., Globigerinoides bisphericus) cooccur. Catapsydrax dissimilis is virtually absent in Sites 872 and 873. Consequently, Zones N6 and N7 could not be distinguished.

\section{Zone N8}

Amended definition. Interval from the FO of Praeorbulina sicana to the FO of Orbulina suturalis.

Discussion. Kennett and Srinivasan (1983) followed Blow (1969) in using the FO of "Globigerinoides sicanus" to recognize the base of Zone N8. These authors thought that $G$. sicanus was the senior synonym of Globigerinoides bisphericus Todd. However, Jenkins et al. (1981) showed that the holotype of Globigerinoides sicanus De Stefani possesses four apertures around the final chamber and thus the two species are not synonyms. "G." sicanus properly belongs in the genus Praeorbulina. Consequently, the correct species concept differs from that used in the zonations of Blow (1969) and Kennett and Srinivasan (1983).

Jenkins et al. (1981) recorded a very close FO of Praeorbulina sican $a$ and $P$. curva. They suggested that the $\mathrm{FO}$ of $P$. curva should be used to identify a redefined Zone N8. However, in this study $P$. sicana is found well below the first appearance of $P$. curva in Sites 871, 872 , and 873 . This level is some way above the FO of Globigerinoides bisphericus.

In this study, the first appearance of $P$. sicana is used to identify Zone N8. This follows other recent works (e.g., Melillo, 1988; Chaisson and Leckie, 1993). The appearance horizon is thought to be above the base of "Zone N8" as used by Blow (1969) and Kennett and 
Srinivasan (1983) but below the base of "Zone N8" as used by Jenkins et al. (1981)

\section{Zone N9}

Definition. Interval from the FO of Orbulina suturalis to the FO of Fohsella peripheroacuta.

Discussion. The Orbulina datum is a prominent biostratigraphic marker in Leg 144 sediments. In Hole 871A, the first appearance of O. suturalis is the culmination of evolution in the Praeorbulina lineage and confirms for the region the well-established sequence of morphospecies recorded elsewhere. However, at Sites 872 and 873 the situation is complicated by reworking.

\section{Zone N10}

Definition. Interval from the FO of Fohsella peripheroacuta to the FO of Fohsella "praefohsi."

Discussion. See discussion of Zone 11 for the recognition of the top of the zone.

\section{Zone N11}

Definition. Interval from the FO of Fohsella "praefohsi" to the FO of Fohsella fohsi.

Discussion. This zone was originally defined by Blow (1969) and is recognized by morphological stages in the apparently continuous Fohsella chronocline. Fohsella "praefohsi" is regarded as the direct precursor to the carinate form Fohsella fohsi and can be consistently recognized in Leg 144 sites. However, the zone was rejected by Bolli and Saunders (1985), who questioned the concept of $F$. praefohsi on the basis of the holotype morphology. In this study, the concept of Kennett and Srinivasan (1983) has been followed, awaiting further taxonomic work.

\section{Zone N12}

Definition. Interval from the FO of Fohsella fohsi to the LO of Fohsella robusta.

Discussion. The first appearance of $F$. fohsi is in a gradual morphological transition from $F$. "praefohsi." Although taxonomic assignment is subjective, the datum appears to correlate well in low latitudes.

\section{Zone N13}

Definition. Interval from the LO of Fohsella robusta to the FO of Globoturborotalita nepenthes.

Discussion. The base of Zone N13 is truncated by unconformity at Sites 871 and 873. At Site 872, Fohsella fohsi s.str. persists to the top of Zone N12 with F. robusta and F. lobata.

\section{Zone N14}

Definition. Interval from the FO of Globoturborotalita nepenthes to the LO of Paragloborotalia mayeri.

Discussion. This zone is absent at all Leg 144 sites.

\section{Zone N15}

Definition. Interval from the LO of Paragloborotalia mayeri to the FO of Neogloboquadrina acostaensis.

Discussion. Zone N15 is absent at Sites 871 and 873. At Site 872, the base is truncated by an unconformity.

\section{Zone N16}

Definition. Interval from the FO of Neogloboquadrina acostaensis to the FO of Globorotalia plesiotumida.
Discussion. Zone N16 is absent at Sites 871 and 873. At Site 872 , the base of the zone lies in an interval of reworking and downhole contamination and so is difficult to identify.

\section{Zone N17}

Definition. Interval from the FO of Globorotalia plesiotumida to the FO of Globorotalia tumida.

\section{Subzone N17a}

Definition. Interval from the FO of Globorotalia plesiotumida to the FO of Pulleniatina primalis.

Discussion. At Site 871, the base of Subzone N17a is truncated by an unconformity. At Site 872, the recognition of the base of the subzone is complicated by downhole contamination. The subzone is absent at Site 873.

\section{Subzone N17b}

Definition. Interval from the FO of Pulleniatina primalis to the FO of Globorotalia tumida.

Discussion. This subzone is present in Sites 871 and 872 but is missing at Site 873. Note that Pulleniatina primalis is frequent in Hole $871 \mathrm{~A}$ but less common in Hole $872 \mathrm{C}$

\section{Zone N18}

Definition. Interval from the FO of Globorotalia tumida to the FO of Sphaeroidinella dehiscens.

Discussion. Zone N18 is absent at Site 871 and thin at Site 872 . At Site 873 , the base of the zone is truncated by an unconformity.

\section{Zone N19}

Definition. Interval from the FO of Sphaeroidinella dehiscens to the initial sinistral to dextral coiling change in Pulleniatina.

Discussion. Sphaeroidinella dehiscens is distinguished from Sphaeroidinellopsis paenedehiscens by the presence of at least one supplementary aperture. The earliest forms of Sphaeroidinella are rare relative to Sphaeroidinellopsis and have just one minute supplementary aperture. Nevertheless, this first appearance does provide a useful datum.

\section{Zone N20}

Definition. Interval from the initial sinistral to dextral coiling shift in Pulleniatina to the FO of Globorotalia tosaensis.

Discussion. The first appearance of Globorotalia pseudopima was originally used to subdivide Zones N19 and N20 (Blow, 1969). This species is absent in Leg 144 material. Kennett and Srinivasan (1983) did not distinguish Zone N19 from Zone N20. In this study, following recent usage (e.g., Chaisson and Leckie, 1993), the base of Zone N20 is recognized by the initial coiling shift in Pulleniatina, which shortly postdates the extinction of Pulleniatina spectabilis. The coiling oscillation is equated to Saito's (1976) "L9" event and appears to correlate globally. Zone N20 was recognized in all three pelagic caps. At Site 871 , its base is truncated by an unconformity.

\section{Zone N21}

Definition. Interval from the FO of Globorotalia tosaensis to the FO of Globorotalia truncatulinoides.

Discussion. Globorotalia tosaensis is rare in Leg 144 material; consequently, the base of Zone N21 is difficult to recognize. In Hole $873 \mathrm{~B}$, Zones N20 and N21 could not be differentiated. 


\section{Zone N22}

Definition. Total range of Globorotalia truncatulinoides.

Discussion. Globorotalia truncatulinoides intergrades with Globorotalia tosaensis, making the exact recognition of the base of Zone N22 somewhat arbitrary. G. truncatulinoides appears below the disappearance of Globigerinoides fistulosus in all three sites. The latter level is used to approximate the Pliocene/Pleistocene boundary.

Blow (1969) differentiated Zones N23 and N22 by the first appearance of Globigerinella calida. In material from Leg 144, G. calida is rare and fully intergrades with $G$. siphonifera; therefore, recognition of this datum has not been attempted.

\section{SITE DESCRIPTIONS}

\section{Limalok Guyot (Site 871)}

Limalok Guyot lies toward the southern end of the eastern Ratak Chain of seamounts (see Fig. 1). Site $871\left(5^{\circ} 33.432^{\prime} \mathrm{N}, 172^{\circ} 20.658^{\prime} \mathrm{E}\right)$ was drilled near the central and thickest part of the pelagic cap. The lithology is unconsolidated foraminifer ooze, except for the top $26.5 \mathrm{~m}$ of nannofossil-foraminifer ooze (Premoli Silva, Haggerty, Rack, et al., 1993). The most complete recovery of pelagic sediments (83\%) was obtained by APC in Hole 871A. The pelagic cap was also recovered in Hole $871 \mathrm{~B}$, but with slightly lower recovery. The most detailed biostratigraphic study was attempted on Hole $871 \mathrm{~A}$, with supporting data from Hole 871B. Ranges of planktonic foraminifers in Hole 871 A are given in Table 1 and a list of biostratigraphic datums in Table 2. A sedimentation rate curve, based on the planktonic foraminifer data given in Table 2, is shown in Figure 3. Both downhole contamination and reworking complicate the biostratigraphy at this site.

The upper Pliocene to Pleistocene of Hole $871 \mathrm{~A}$ is apparently complete (see the nannofossil evidence presented in Premoli Silva, Haggerty, Rack, et al., 1993). The LO of pink Globigerinoides ruber $(0.12 \mathrm{Ma})$ is in Sample 144-871 A-1H-2, 59-61 cm. The coiling preference of the Pulleniatina lineage is shown in Figure 4 and Table 3. The LO of abundant sinistrally coiled specimens is found in Sample $144-871 \mathrm{~A}-2 \mathrm{H}-1,60-62 \mathrm{~cm}$. This coiling event probably correlates with Saito's (1976) "L1" event, which has been recorded at a variety of sites between the Jaramillo and Brunhes normal polarity intervals (approximately $0.8 \mathrm{Ma}$ ).

A significant overlap exists in the ranges of Globorotalia truncatulinoides and Globigerinoides fistulosus (i.e., the interval from Samples 144-871A-3H-1, 60-62 cm, through -3H-2, 60-62 cm). In conjunction with the nannofossil data, this interval is interpreted as being of latest Pliocene age and represents the lowest part of Zone N22.

Core $144-871 \mathrm{~A}-3 \mathrm{H}$ is a condensed section and consequently was studied at higher resolution (two samples per section). Fragmentation is severe throughout most of the core. At least one distinct hiatus exists within the core and others may be present, although reworking and unavoidable mixing of sediment in the core barrels has rendered interpretations difficult. Sample 144-871A-3H-2, 123-125 cm, belongs to Zone N21. Samples in Section 144-871A-3H-3 belong to Zone N20 (i.e., postdating the initial coiling reversal in the Pulleniatina lineage; see Fig. 4), although some species from directly below are apparently reworked into this section. A hiatus exists between these samples and samples in Section 144-871A-3H-4, which belong to Subzone N17b. The remainder of the core (i.e., Sections 144-871 A-3H-5 and -3H-6 and Sample 144-871A-3H-CC) belongs to Subzone N17a.

The top of Core 144-871A-4H contains various middle Miocene marker species, including the Fohsella group. Thus, a major hiatus exists between Core 144-871 A-3H and $-4 \mathrm{H}$. However, also present in the interval from Samples 144-871A-4H-1, 126-128 cm, through $-4 \mathrm{H}-3,59-61 \mathrm{~cm}$, is a significant amount of younger material as downhole contaminants (approaching 50\% in the worst cases). Similar contamination also exists at this level in Hole 871B. Consequently, it has been impossible to assess the extent of reworking at the level of the hiatus itself.
Zone N12 is thick at Site 871, occupying almost all of Cores $144-871 \mathrm{~A}-4 \mathrm{H},-5 \mathrm{H}$, and $-6 \mathrm{H}$. Fragmentation is moderate to severe. This probably represents nearly the full thickness of the zone, because Fohsella robusta, the most advanced representative of the genus, is present below the hiatus. Moderate levels of reworking of slightly older sediment, probably from Zone N10, is seen in the top three sections of Core 144-871A-6H. A short hiatus has been identified between Samples 144-871A-6H-6, 60-62 cm, and -6H-CC. Zone N11 is missing at this hiatus. Sample 144-871 A-6H-6, 60-62 cm, is apparently a thoroughly mixed assemblage, containing elements of both Zones $\mathrm{N} 10$ and N12.

The planktonic foraminifer zonation of Cores $144-871 \mathrm{~A}-7 \mathrm{H},-8 \mathrm{H}$, and $-9 \mathrm{H}$ is relatively straightforward, with all the important zonal fossils present. Fragmentation is mostly light or moderate. This part of the sequence is apparently complete, from Zone N10 down to Zone N7. Minor reworking is identified by the presence of sporadic Praeorbulina spp. high in Core 144-871 A-7H. However, the first appearances of the various Praeorbulina morphospecies that are not affected by reworking permit a relatively precise biostratigraphy.

The zonation of the rest of the hole below Core 144-871A-9H is complicated by frequent reworking, which increases in severity with depth. Fragmentation is, however, variable and even light for most of Cores $144-871 \mathrm{~A}-14 \mathrm{H}$ and $-15 \mathrm{H}$. A further problem is the rarity of the zonal fossils Catapsydrax and Globigerinatella and the taxonomic problems associated with the latter (see the taxonomic discussion of Globigerinatella below).

The LO of Catapsydrax dissimilis occurs in the same sample as the LO of C. unicavus (Sample 144-871A-10H-5, 59-61 cm). However, this biohorizon must be regarded with caution because Catapsydrax is rare in all samples at this site and Core $144-871 \mathrm{~A}-10 \mathrm{H}$ is noticeably affected by reworking (e.g., Globoquadrina binaensis is present in some samples). It is not possible to decide whether the rare specimens of Catapsydrax are in situ or reworked. Consequently, Zones N6 and N7 were not differentiated.

In standard zonations such as Kennett and Srinivasan (1983), the bottom of Zone N6 is marked by the first appearance of Globigerinatella insueta. The first Globigerinatella in this site are found in Sample 144-871A-13H-CC. Although more confidence can be attached to this biohorizon because it is a first appearance datum and so cannot be moved upward by reworking, some caution is still urged. This is because the appearance of Globigerinatella insueta has been described as an abrupt occurrence (Bolli and Saunders, 1985), whereas in this section a gradual transition from Globigerinita glutinata s.l. was observed. "Fully developed" $G$. insueta s.str. (i.e., specimens possessing areal apertures or areal bullae) do not occur until considerably higher in the sequence, in Sample 144-871 A-11H-5, $124-126 \mathrm{~cm}$. This issue is discussed in detail in the taxonomic section (see also Fig. 14).

The remainder of the hole (i.e., Cores $144-871 \mathrm{~A}-14 \mathrm{H}$ and $-15 \mathrm{H}$ ) is a thoroughly mixed interval. The frequent presence of forms such as Globigerinoides trilobus and Globoquadrina dehiscens indicates that the base of the pelagic cap is not older than early Miocene. Because of upward reworking of the N4 zonal marker Paragloborotalia kugleri throughout Cores $144-871 \mathrm{~A}-14 \mathrm{H}$ and $-13 \mathrm{H}$ and higher into Zones N6 and N7, it is impossible to distinguish Zone N5 from Zone N4.

\section{Lo-En Guyot (Site 872)}

Lo-En Guyot is one of a cluster of seamounts south of Anewetak Atoll in the western part of the Marshall Islands region. Site 872 $\left(10^{\circ} 05.850^{\prime} \mathrm{N}, 162^{\circ} 51.960^{\prime} \mathrm{E}\right)$ is positioned centrally on the guyot. The lithology is foraminifer ooze, except for the top $30 \mathrm{~m}$, which is nannofossil-foraminifer ooze (see Premoli Silva, Haggerty, Rack, et al. 1993). The full thickness of pelagic sediments was recovered, which is the thickest such section in the Marshall Islands region. Two holes were drilled by APC (Holes $872 \mathrm{~A}$ and $872 \mathrm{C}$ ). The most com- 


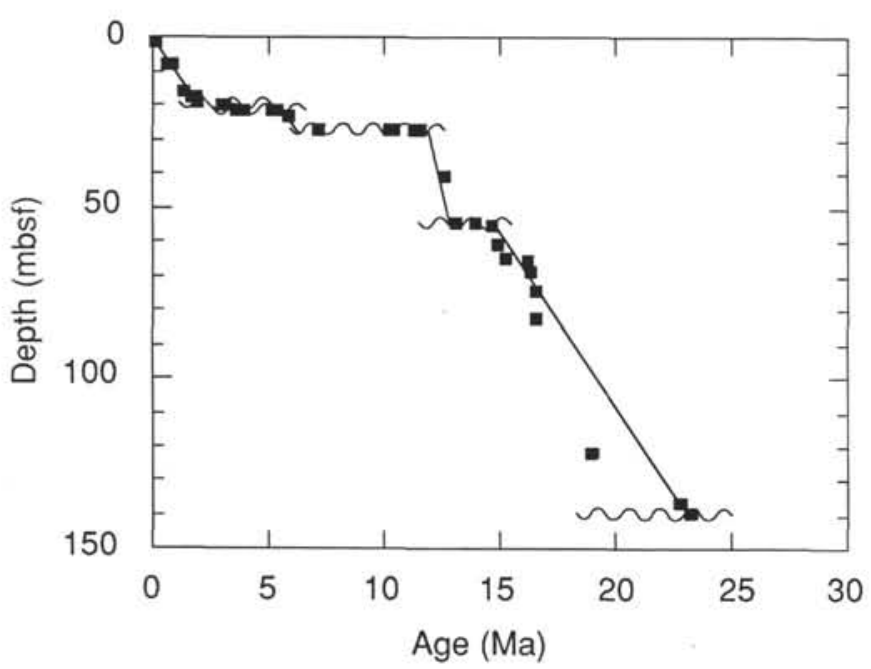

Figure 3. Sediment accumulation curve for the pelagic cap of Limalok Guyot (Hole 871A). Squares represent planktonic foraminifer datums listed in Table 2.

plete recovery was obtained in Hole $872 \mathrm{C}(98.5 \%)$, which was selected for detailed biostratigraphic investigation. Ranges of planktonic foraminifers are given in Table 4 , and biostratigraphic datums are summarized in Table 5. A sediment accumulation curve is plotted in Figure 5 from the planktonic foraminifer data given in Table 5. Downhole contamination is a serious problem in some cores and reworking is common.

The Pliocene-Pleistocene interval at Site 872 is severely affected by fragmentation. The highest sample examined (Sample 144-872C$1 \mathrm{H}-1,58-60 \mathrm{~cm}$ ) contains pink Globigerinoides ruber and so is older than $120,000 \mathrm{yr}$. The Globorotalia tosaensis-truncatulinoides group is scarce at this site but sufficiently abundant in large samples to be suitable for Pliocene-Pleistocene biostratigraphy. Zone N22 is present in Hole 872C down to Sample 144-872C-2H-1, 58-60 cm. Globigerinoides fistulosus is associated with Globorotalia truncatulinoides in Samples $144-872 \mathrm{C}-1 \mathrm{H}-\mathrm{CC}$ and $-2 \mathrm{H}-1,58-60 \mathrm{~cm}$, and suggests a latest Pliocene age at the base of Zone N22 for these samples. Zone N21 is present down to Sample 144-872C-2H-CC.

Coiling counts of the Pulleniatina lineage are shown in Figure 6 and Table 6 . The two events used as biostratigraphic datums in this work are marked with asterisks. The final switch to a strong dextral preference (Saito's [1976] "L1" event) occurs between Samples 144$872 \mathrm{C}-1 \mathrm{H}-3,58-60 \mathrm{~cm}$, and $-1 \mathrm{H}-4,58-60 \mathrm{~cm}$. The initial switch away from a strong sinistral preference (Saito's "L9" event), used to mark the base of Zone N20, occurs between Samples 144-872C-3H-4, $118-120 \mathrm{~cm}$, and $-3 \mathrm{H}-5,59-61 \mathrm{~cm}$.

The base of Zone N19, which is identified by the first appearance of Sphaeroidinella dehiscens, is problematic because of downhole contamination of this species in Core 144-872C-4H. However, Sample 144-872C-3H-CC lacks Sphaeroidinella but contains Globorotalia tumida and so is placed in Zone N18. Sample 144-872C-4H-1, $59-61 \mathrm{~cm}$, not only contains Sphaeroidinella but also frequent $G$. tumida. However, all these specimens are probably downhole contaminants from the top of the hole, judging by their style of preservation. The assignment of this sample to Subzone N17b is supported by the lack of Pulleniatina spectabilis in Core $144-872 \mathrm{C}-4 \mathrm{H}$.

Pulleniatina primalis is rare at the bottom of its range, but it was found in Sample 144-872C-4H-6, 59-61 cm, marking the base of Subzone N17b. Sample 144-872C-4H-CC lacks $P$. primalis but contains Globorotalia plesiotumida and so is placed in Subzone N17a. The presence or absence of $G$. plesiotumida in the top half of Core $144-872 \mathrm{C}-5 \mathrm{H}$ has proved difficult to determine because of frequent downhole contamination of $G$. tumida (inevitably accompanied by some juvenile specimens that resemble G. plesiotumida), and also $G$.

\section{Dextral coiling (\%)}

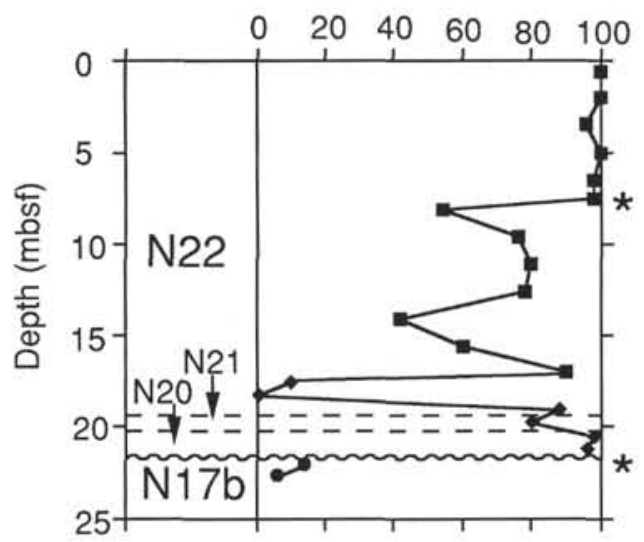

Figure 4. Coiling ratios of Pulleniatina from Limalok Guyot (Hole 871A). Each measurement was made on an examination of 50 specimens. Data are presented in Table 3. Asterisks mark the datums used for correlation in this study (see text). Circles $=$ Pulleniatina primalis, diamonds $=$ Pulleniatina praecursor , and squares = Pulleniatina obliquiloculata .

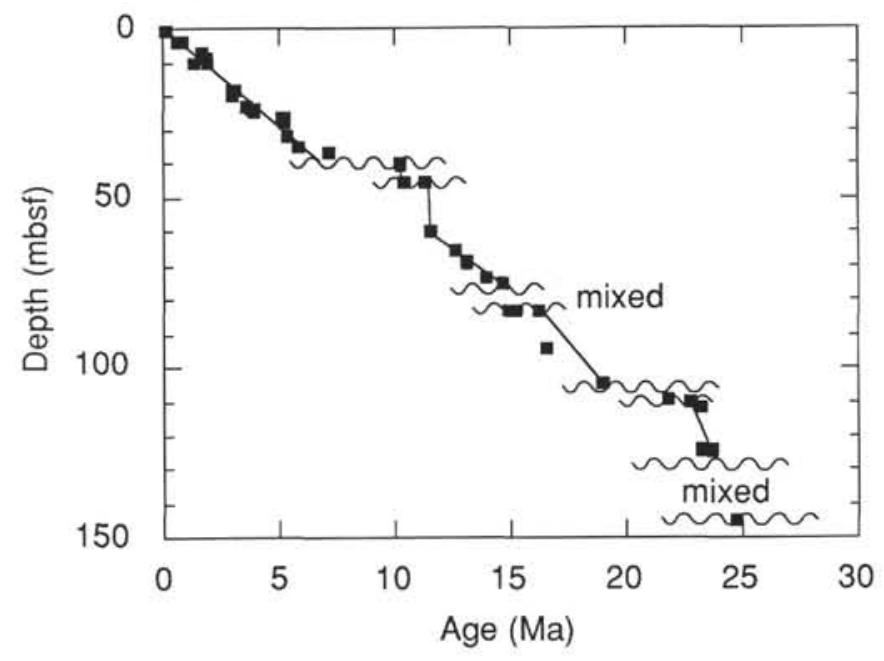

Figure 5. Sediment accumulation curve for the pelagic cap of Lo-En Guyot (Hole $872 \mathrm{C}$ ). Squares represent planktonic foraminifer datums listed in Table 5.

\section{Dextral coiling (\%)}

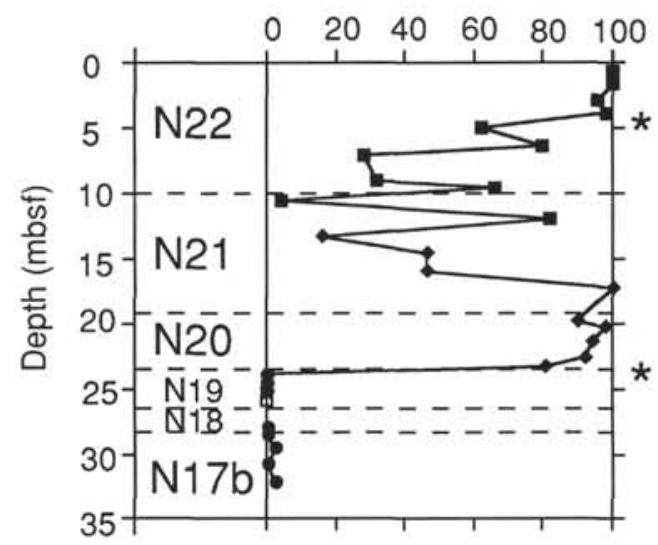

Figure 6. Coiling ratios of Pulleniatina from Lo-En Guyot (Hole 872C). Each measurement was made on an examination of 50 specimens. Data are presented in Table 6. Asterisks mark the datums used for correlation in this study (see text). Circles $=$ Pulleniatina primalis, diamonds $=$ Pulleniatina praecursor, solid squares $=$ Pulleniatina obliquiloculata, open squares $=$ Pulleniatina praespectabilis, and crosses $=$ Pulleniatina spectabilis . 


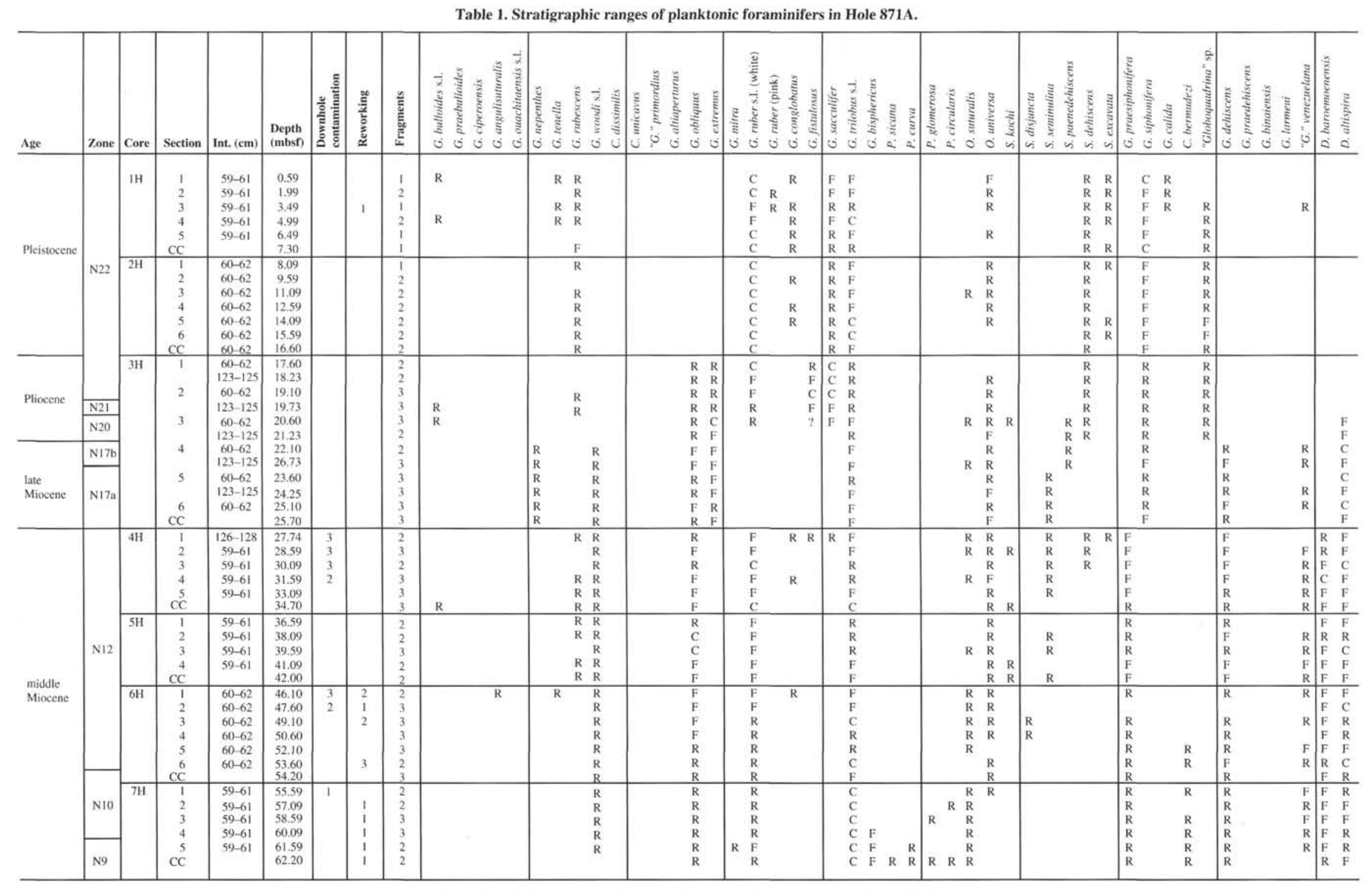


Table 1 (continued).

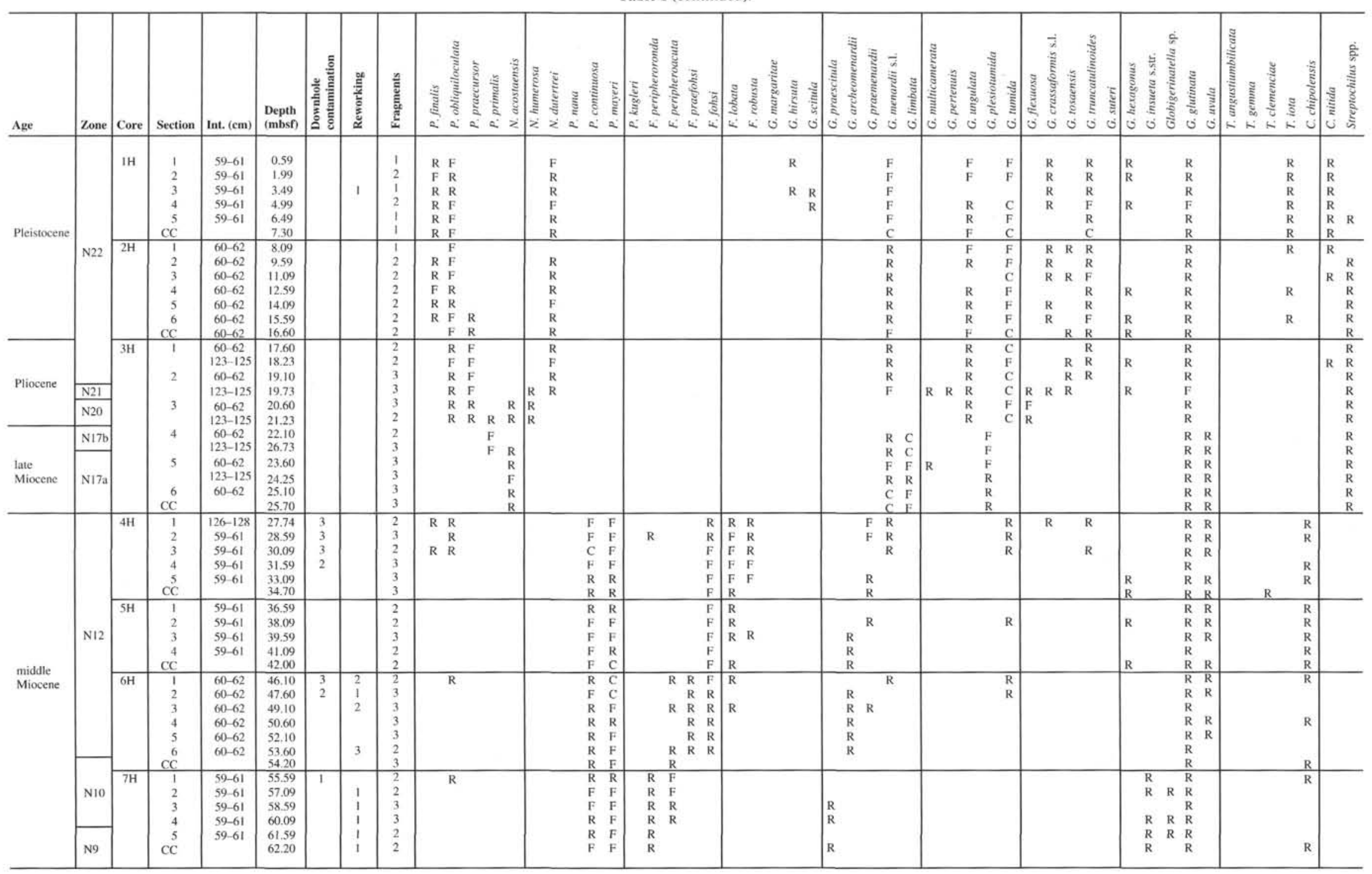


Table 1 (continued).

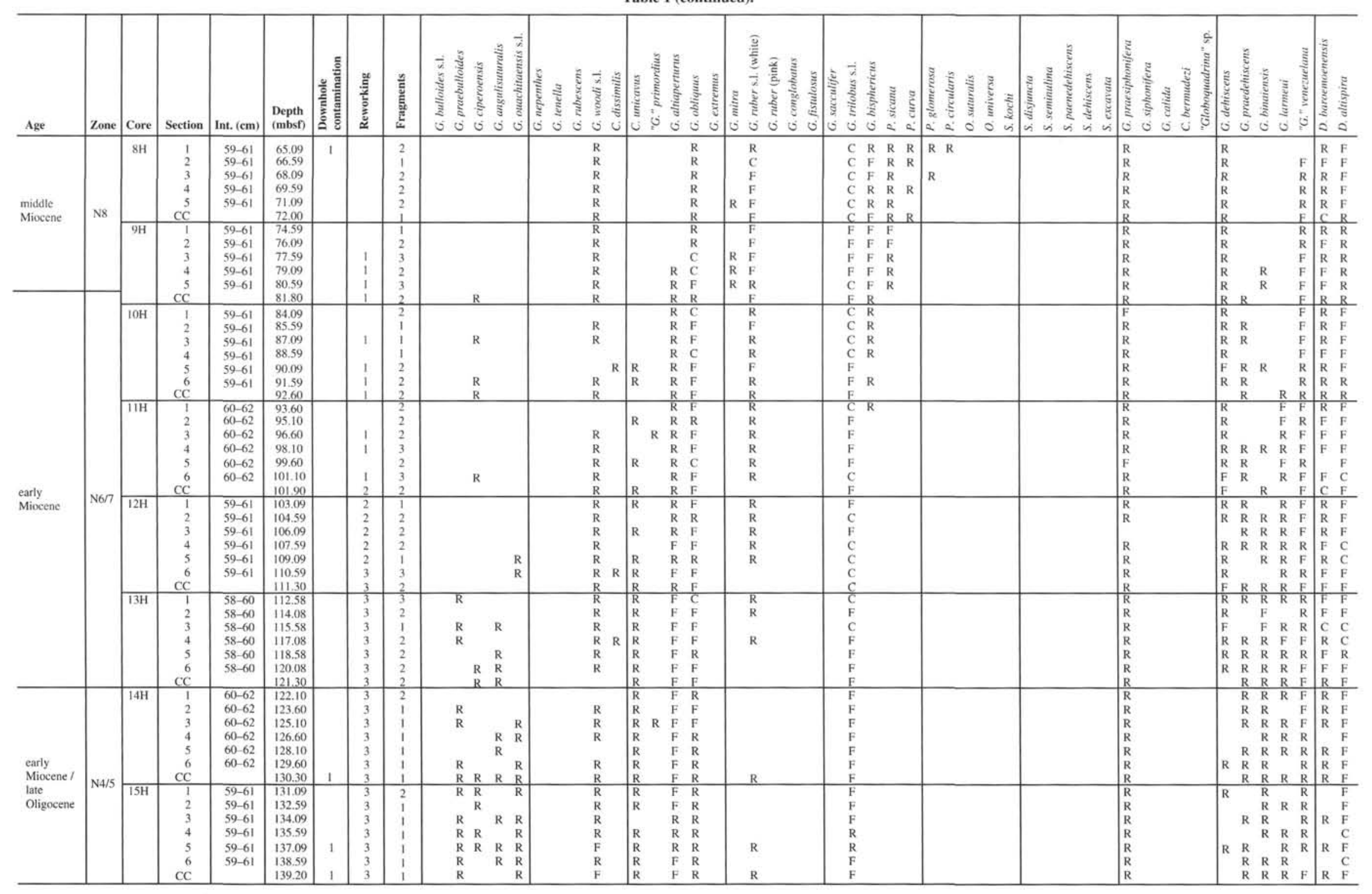


Table 1 (continued),

\begin{tabular}{|c|c|c|c|c|c|c|c|c|c|c|c|c|c|c|c|c|c|c|c|c|c|c|c|c|}
\hline Age & Zone & Core & Section & Int. (cm) & $\begin{array}{c}\text { Depth } \\
\text { (mbsi) }\end{array}$ & 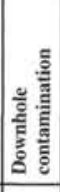 & 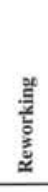 & 炁 & 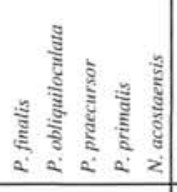 & 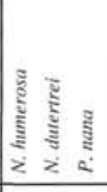 & $\begin{array}{c}8 \\
8 \\
2 \\
2\end{array}$ & : & 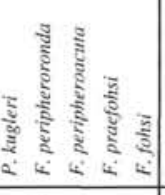 & 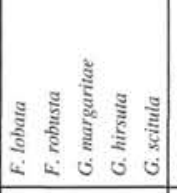 & 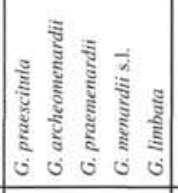 & 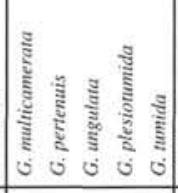 & 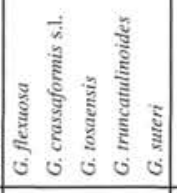 & 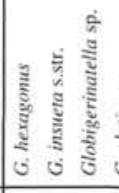 & 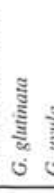 & & 产 & हूँ हूँ & 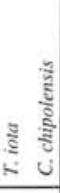 & 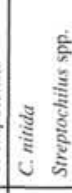 \\
\hline \multirow[t]{2}{*}{$\begin{array}{l}\text { middle } \\
\text { Miocene }\end{array}$} & \multirow[t]{2}{*}{ N8 } & $8 \mathrm{H}$ & $\begin{array}{r}1 \\
2 \\
3 \\
4 \\
5 \\
\mathrm{CC} \\
\end{array}$ & \begin{tabular}{l|}
$59-61$ \\
$59-61$ \\
$59-61$ \\
$59-61$ \\
$59-61$
\end{tabular} & $\begin{array}{l}65.09 \\
66.59 \\
68.09 \\
69.59 \\
71.09 \\
72.00 \\
\end{array}$ & 1 & & $\begin{array}{l}2 \\
1 \\
2 \\
2 \\
2 \\
1\end{array}$ & & & $\begin{array}{l}\mathrm{R} \\
\mathrm{R} \\
\mathrm{R} \\
\mathrm{F} \\
\mathrm{R} \\
\mathrm{R}\end{array}$ & \begin{tabular}{l|l}
$R$ & \\
$F$ & \\
$F$ & \\
$F$ & \\
$R$ & \\
$F$ &
\end{tabular} & $\begin{array}{l}\mathrm{R} \\
\mathrm{R} \\
\mathrm{R} \\
\mathrm{R} \\
\mathrm{R} \\
\mathrm{R} \\
\end{array}$ & & $\begin{array}{|ll|} & R \\
R & R \\
R & R \\
R & R \\
R & R \\
R & R \\
& R \\
\end{array}$ & & & \begin{tabular}{ll|l}
$R$ & $R$ \\
$R$ & \\
$R$ & $R$ \\
$R$ & \\
$R$ & & \\
$R$ & & \\
$R$ &
\end{tabular} & $\begin{array}{ll}R \\
R \\
R \\
R \\
R \\
R \\
R \\
R\end{array}$ & & & $\mathrm{R}$ & $\begin{array}{l}\mathrm{R} \\
\mathrm{R}\end{array}$ & \\
\hline & & \begin{tabular}{|l|}
$9 \mathrm{H}$ \\
\end{tabular} & $\begin{array}{r}1 \\
2 \\
3 \\
4 \\
5 \\
\mathrm{CC}\end{array}$ & $\begin{array}{l}59-61 \\
59-61 \\
59-61 \\
59-61 \\
59-61\end{array}$ & $\begin{array}{l}74.59 \\
76.09 \\
77.59 \\
79.09 \\
80.59 \\
81.80 \\
\end{array}$ & & $\begin{array}{l}1 \\
1 \\
1 \\
1\end{array}$ & $\begin{array}{l}1 \\
2 \\
3 \\
2 \\
3 \\
2 \\
\end{array}$ & & & $\begin{array}{l}\mathrm{R} \\
\mathrm{R} \\
\mathrm{F} \\
\mathrm{F} \\
\mathrm{R} \\
\mathrm{R} \\
\mathrm{R}\end{array}$ & $\begin{array}{l}\mathrm{F} \\
\mathrm{F} \\
\mathrm{F} \\
\mathrm{R} \\
\mathrm{R} \\
\mathrm{R} \\
\mathrm{R}\end{array}$ & $\begin{array}{l}\mathrm{R} \\
\mathrm{R} \\
\mathrm{R} \\
\mathrm{R} \\
\mathrm{R} \\
\mathrm{R}\end{array}$ & & 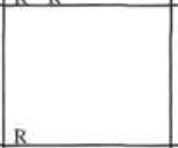 & & & $\begin{array}{ll}\mathrm{R} & \mathrm{R} \\
\mathrm{R} & \mathrm{R} \\
\mathrm{R} & \\
\mathrm{R} & \mathrm{R} \\
\mathrm{R} & \mathrm{R} \\
\end{array}$ & $\begin{array}{ll}K & \\
R & \\
R & R \\
R & R \\
R & R \\
R & \\
R & \\
R & \end{array}$ & & & $R$ & $\begin{array}{l}R \\
R \\
R \\
R \\
R \\
R \\
R\end{array}$ & \\
\hline \multirow{4}{*}{$\begin{array}{l}\text { early } \\
\text { Miocene }\end{array}$} & \multirow{4}{*}{$\mathrm{N} 6 / 7$} & $10 \mathrm{H}$ & $\begin{array}{r}1 \\
2 \\
3 \\
4 \\
5 \\
6 \\
6 \\
C\end{array}$ & \begin{tabular}{l|}
$59-61$ \\
$59-61$ \\
$59-61$ \\
$59-61$ \\
$59-61$ \\
$59-61$ \\
\end{tabular} & $\begin{array}{l}84.09 \\
85.59 \\
87.09 \\
88.59 \\
90.09 \\
9.59 \\
92.60 \\
\end{array}$ & & $\begin{array}{l}1 \\
1 \\
1 \\
1 \\
\end{array}$ & $\begin{array}{l}-2 \\
1 \\
1 \\
1 \\
2 \\
2 \\
2 \\
\end{array}$ & & & $\begin{array}{l}R \\
R \\
R \\
R \\
R \\
R \\
R \\
\end{array}$ & \begin{tabular}{l|l}
$F$ & \\
$R$ & $R$ \\
$F$ & $R$ \\
$R$ & $R$ \\
$F$ & $R$ \\
$F$ & \\
$R$ &
\end{tabular} & $\begin{array}{ll} & R \\
R & R \\
R & R \\
R & \\
R & \end{array}$ & & & & & $\begin{array}{ll:l}R & R & \\
R & R & 1 \\
R & R & \\
R & R & \\
R & R & \\
R & R & \\
R & R & \\
\end{array}$ & $\begin{array}{ll}R & R \\
R & R \\
R & \\
R & \\
R & R \\
R & R \\
R & R \\
R & R \\
& R \\
\end{array}$ & \begin{tabular}{l|l}
$R$ & $R$ \\
$R$ & \\
$R$ & \\
$R$ & \\
$R$ & $B$ \\
$R$
\end{tabular} & R & & $\begin{array}{l}\mathrm{R} \\
\mathrm{R} \\
\mathrm{R} \\
\mathrm{R} \\
\end{array}$ & \\
\hline & & $11 \mathrm{H}$ & $\begin{array}{r}1 \\
2 \\
3 \\
4 \\
5 \\
6 \\
\text { CC } \\
\end{array}$ & $\begin{array}{l}60-62 \\
60-62 \\
60-62 \\
60-62 \\
60-62 \\
60-62 \\
\end{array}$ & $\begin{array}{l}93.60 \\
95.10 \\
96.60 \\
98.10 \\
99.60 \\
101.10 \\
101.90 \\
\end{array}$ & & $\begin{array}{l}1 \\
1 \\
1 \\
2 \\
2\end{array}$ & $\begin{array}{l}2 \\
2 \\
2 \\
3 \\
2 \\
3 \\
2 \\
\end{array}$ & & & $\begin{array}{l}R \\
R \\
R \\
R \\
R \\
R \\
R \\
\end{array}$ & $\begin{array}{l}F \\
F \\
R \\
F \\
R \\
R \\
F \\
\end{array}$ & & & & & & $\begin{array}{ll:l}R & R & \\
R & F & 1 \\
R & R & 1 \\
R & R & 1 \\
R & F & F \\
& R & 1 \\
& R & \\
\end{array}$ & $\begin{array}{lll}R & \text { R } \\
R & \\
R & \\
R & R \\
R & R \\
R & R \\
R & R \\
R & R \\
& R \\
\end{array}$ & & & $\begin{array}{l}R \\
R \\
R \\
R \\
R \\
R\end{array}$ & $\begin{array}{l}R \\
R \\
R \\
R \\
R \\
R \\
\end{array}$ & \\
\hline & & $12 \mathrm{H}$ & $\begin{aligned} 1 \\
2 \\
3 \\
4 \\
5 \\
6 \\
6 \\
\text { CC }\end{aligned}$ & $\begin{array}{l}59-61 \\
59-61 \\
59-61 \\
59-61 \\
59-61 \\
59-61\end{array}$ & $\begin{array}{l}103.09 \\
104.59 \\
106.09 \\
107.59 \\
109.09 \\
110.59 \\
111.30 \\
\end{array}$ & & $\begin{array}{l}2 \\
2 \\
2 \\
2 \\
2 \\
3 \\
3 \\
\end{array}$ & $\begin{array}{l}1 \\
2 \\
2 \\
2 \\
1 \\
3 \\
2 \\
\end{array}$ & & & $\begin{array}{l}\mathrm{R} \\
\mathrm{R} \\
\mathrm{R} \\
\mathrm{R} \\
\mathrm{R}\end{array}$ & \begin{tabular}{l|l}
$R$ & \\
$F$ & \\
$C$ & \\
$R$ & \\
$F$ & $R$ \\
$R$ & \\
$R$ &
\end{tabular} & $\mathrm{R}$ & & & & \begin{tabular}{l|l}
$R$ \\
$R$
\end{tabular} & $\begin{array}{ll}R & \\
R & \\
R & \\
R & \\
R & \\
R & \\
R & \end{array}$ & $\begin{array}{ll}R & R \\
R & \\
R & \\
R & R \\
R & R \\
R & R \\
R & R \\
R & R\end{array}$ & & $\begin{array}{l}\mathrm{R} \\
\mathrm{R}\end{array}$ & $\begin{array}{l}R \\
R \\
R \\
R \\
R\end{array}$ & $\begin{array}{l}R \\
R \\
R \\
R \\
R \\
R \\
R \\
R \\
\end{array}$ & \\
\hline & & $13 \mathrm{H}$ & $\begin{array}{r}1 \\
2 \\
3 \\
4 \\
5 \\
6 \\
\text { CC } \\
\end{array}$ & \begin{tabular}{|l|}
$58-60$ \\
$58-60$ \\
$58-60$ \\
$58-60$ \\
$58-60$ \\
$58-60$
\end{tabular} & \begin{tabular}{l|}
112.58 \\
114.08 \\
115.58 \\
117.08 \\
118.58 \\
120.08 \\
121.30 \\
\end{tabular} & & $\begin{array}{l}3 \\
3 \\
3 \\
3 \\
3 \\
3 \\
3 \\
3 \\
3 \\
\end{array}$ & $\begin{array}{l}3 \\
3 \\
1 \\
2 \\
2 \\
2 \\
2 \\
\end{array}$ & & & $\begin{array}{l}R \\
R \\
R \\
R \\
R \\
R \\
R \\
\end{array}$ & \begin{tabular}{l|l}
$R$ & $R$ \\
$F$ & $R$ \\
$F$ & $R$ \\
$F$ & $R$ \\
$F$ & $R$ \\
$R$ & $R$ \\
$R$ & $R$ \\
$R$ & $R$
\end{tabular} & $\begin{array}{l}R \\
R \\
R \\
R \\
R \\
R \\
R \\
R \\
R\end{array}$ & & & & \begin{tabular}{l|l}
$R$ & \\
$R$ &
\end{tabular} & $\begin{array}{ll}R & \\
R & \\
R & \\
R & \\
R & \\
R & \\
\end{array}$ & $\begin{array}{ll}R & N \\
R & R \\
R & R \\
R & R \\
R & R \\
R & R \\
R & R \\
R & R \\
& R \\
\end{array}$ & & R & R & $\begin{array}{l}R \\
R \\
R \\
R \\
R \\
R \\
R \\
R \\
\end{array}$ & \\
\hline \multirow{2}{*}{$\begin{array}{l}\text { early } \\
\text { Miocene / } \\
\text { late } \\
\text { Oligocene }\end{array}$} & \multirow[t]{2}{*}{$\mathrm{N} 4 / 5$} & $14 \mathrm{H}$ & $\begin{array}{r}1 \\
2 \\
3 \\
4 \\
5 \\
6 \\
\mathrm{CC} \\
\end{array}$ & $\begin{array}{l}60-62 \\
60-62 \\
60-62 \\
60-62 \\
60-62 \\
60-62 \\
\end{array}$ & \begin{tabular}{l|}
122.10 \\
123.60 \\
125.10 \\
126.60 \\
128.10 \\
129.60 \\
130.30 \\
\end{tabular} & 1 & $\begin{array}{l}3 \\
3 \\
3 \\
3 \\
3 \\
3 \\
3 \\
3 \\
\end{array}$ & $\begin{array}{l}2 \\
1 \\
1 \\
1 \\
1 \\
1 \\
1 \\
\end{array}$ & & & $\begin{array}{l}R \\
R \\
R \\
R \\
R \\
R\end{array}$ & \begin{tabular}{l|l}
$R$ & $R$ \\
$R$ & \\
$R$ & \\
$R$ & \\
$R$ & \\
$R$ & \\
$R$ & $R$ \\
\end{tabular} & R & & & & $\begin{array}{l}\mathrm{R} \\
\mathrm{R} \\
\mathrm{R} \\
\mathrm{R}\end{array}$ & & $\begin{array}{ll}K & K \\
R & R \\
R & R \\
R & R \\
R & \\
R & R \\
R & \\
R & R \\
& R\end{array}$ & $\begin{array}{lll}R & \\
R & B \\
R & B \\
R & B \\
R & B \\
R\end{array}$ & $\begin{array}{r}\mathbf{R} \\
\mathbf{R}\end{array}$ & $\begin{array}{l}\mathrm{R} \\
\mathrm{R} \\
\mathrm{R} \\
\mathrm{R} \\
\mathrm{R} \\
\mathrm{R}\end{array}$ & $\begin{array}{l}\mathrm{R} \\
\mathrm{R} \\
\mathrm{R} \\
\mathrm{R} \\
\mathrm{B}\end{array}$ & \\
\hline & & $15 \mathrm{H}$ & $\begin{array}{r}1 \\
2 \\
3 \\
4 \\
5 \\
6 \\
\mathrm{CC} \\
\end{array}$ & $\begin{array}{l}59-61 \\
59-61 \\
59-61 \\
59-61 \\
59-61 \\
59-61\end{array}$ & \begin{tabular}{l|}
131.09 \\
132.59 \\
134.09 \\
135.59 \\
137.09 \\
138.59 \\
139.20 \\
\end{tabular} & $\begin{array}{l}1 \\
1 \\
\end{array}$ & $\begin{array}{l}3 \\
3 \\
3 \\
3 \\
3 \\
3 \\
3 \\
3 \\
\end{array}$ & $\begin{array}{l}2 \\
1 \\
1 \\
1 \\
1 \\
1 \\
1 \\
\end{array}$ & & & $\begin{array}{l}\mathrm{R} \\
\mathrm{R} \\
\mathrm{R} \\
\mathrm{R} \\
\mathrm{R} \\
\mathrm{R} \\
\mathrm{R} \\
\end{array}$ & $\begin{array}{l}\mathrm{R} \\
\mathrm{F} \\
\mathrm{F} \\
\mathrm{F} \\
\mathrm{F} \\
\mathrm{F} \\
\mathrm{F} \\
\end{array}$ & & & & & $\begin{array}{l}\mathrm{R} \\
\mathrm{R}\end{array}$ & & $\begin{array}{ll}R & R \\
R & R \\
R & R \\
R & \\
R & R \\
R & R \\
R & R \\
\end{array}$ & \begin{tabular}{l|l}
$R$ & \\
$R$ & $R$ \\
$R$ & $R$ \\
$R$ & $R$ \\
$R$ & $R$ \\
$R$ & $R$ \\
\end{tabular} & $\begin{array}{lll} & \\
R & \\
R & R \\
R & R \\
R & \\
R & \\
R & R \\
\end{array}$ & $\begin{array}{l}\mathrm{R} \\
\mathrm{R} \\
\mathrm{R} \\
\mathrm{R} \\
\mathrm{R} \\
\mathrm{R} \\
\mathrm{R} \\
\end{array}$ & $\begin{array}{l}\mathrm{R} \\
\mathrm{R}\end{array}$ & \\
\hline
\end{tabular}


Table 2. Planktonic foraminifer datums in Hole 871A and their stratigraphic positions.

\begin{tabular}{|c|c|c|c|c|c|c|c|}
\hline \multirow[b]{2}{*}{ Datum } & & \multirow{2}{*}{$\begin{array}{c}\text { Stratigraphic } \\
\text { position }\end{array}$} & \multirow{2}{*}{$\begin{array}{l}\text { Age } \\
\text { (Ma) }\end{array}$} & \multicolumn{2}{|c|}{ Core, section, interval $(\mathrm{cm})$} & \multirow{2}{*}{$\begin{array}{l}\text { Depth } \\
\text { (mbsf) }\end{array}$} & \multirow{2}{*}{$\begin{array}{l}\text { Interpolated } \\
\text { depth } \\
\text { (mbsf) }\end{array}$} \\
\hline & & & & Top & Bottom & & \\
\hline LO & Pink Globigerinoides ruber & & 0.12 & $1 \mathrm{H}-1,124-126$ & $1 \mathrm{H}-2,59-61$ & $1.24-2.09$ & 1.66 \\
\hline LO & Globorotalia tosaensis & & 0.6 & $\mathrm{IH}-\mathrm{CC}$ & $2 \mathrm{H}-1,60-62$ & $7.30-8.09$ & 7.70 \\
\hline & Pulleniatina, last coiling reversal & & 0.8 & IH-CC & $2 \mathrm{H}-1,60-62$ & $7.30-8.09$ & 7.70 \\
\hline FO & Pulleniatina finalis & & 1.3 & $2 \mathrm{H}-6,60-62$ & $2 \mathrm{H}-\mathrm{CC}$ & $15.59-16.60$ & 16.10 \\
\hline LO & Globigerinoides fistulosus & Pliocene/Pleistocene & 1.6 & $2 \mathrm{H}-\mathrm{CC}$ & $3 \mathrm{H}-1,60-62$ & $17.00-17.60$ & 17.30 \\
\hline LO & Globigerinoides extremus & & 1.8 & $2 \mathrm{H}-\mathrm{CC}$ & $3 \mathrm{H}-1,60-62$ & $17.00-17.60$ & 17.30 \\
\hline FO & Globorotalia truncatulinoides & Base N22/Top N2I & 1.9 & $3 \mathrm{H}-2,60-62$ & $3 \mathrm{H}-2,123-125$ & $19.10-19.73$ & 19.42 \\
\hline LO & Dentoglobigerina altispira & & 2.9 & $3 \mathrm{H}-2,123-125$ & $3 \mathrm{H}-3,60-62$ & $19.73-20.60$ & 20.16 \\
\hline $\mathrm{FO}$ & Globigerinoides fistulosus & & 2.9 & $3 \mathrm{H}-2,123-125$ & $3 \mathrm{H}-3,60-62$ & $19.73-20.60$ & 20.16 \\
\hline LO & Sphaeroidinellopsis & & 3.0 & $3 \mathrm{H}-2,123-125$ & $3 \mathrm{H}-3,60-62$ & $19.73-20.60$ & 20.16 \\
\hline FO & Globorotalia tosaensis & Base N21/Top N20 & 3.1 & $3 \mathrm{H}-2,123-125$ & $3 \mathrm{H}-3,60-62$ & $19.73-20.60$ & 20.16 \\
\hline LO & Pulleniatina primalis & Base N20/Top N19 & 3.5 & $3 \mathrm{H}-3,123-125$ & $3 \mathrm{H}-4,60-62$ & $21.23-22.10$ & 21.66 \\
\hline & Pulleniatina, first coiling reversal & & 3.8 & $3 \mathrm{H}-3,123-125$ & $3 \mathrm{H}-4,60-62$ & $21.23-22.10$ & 21.66 \\
\hline LO & Globoturborotalita nepenthes & & 3.9 & $3 \mathrm{H}-3,123-125$ & $3 \mathrm{H}-4,60-62$ & $21.23-22.10$ & 21.66 \\
\hline FO & Sphaeroidinalla dehiscens & Base N19/Top N18 & 5.1 & $3 \mathrm{H}-3,123-125$ & $3 \mathrm{H}-4,60-62$ & $21.23-22.10$ & 21.66 \\
\hline FO & Globorotalia tumida & Base N18/Top N17B & 5.2 & $3 \mathrm{H}-3,123-125$ & $3 \mathrm{H}-4,60-62$ & $21.23-22.10$ & 21.66 \\
\hline FO & Globigerinoides conglobatus & & 5.3 & $3 \mathrm{H}-3,123-125$ & $3 \mathrm{H}-4,60-62$ & $21.23-22.10$ & 21.66 \\
\hline LO & Globoquadrina dehiscens & & 5.3 & $3 \mathrm{H}-3,123-125$ & $3 \mathrm{H}-4,60-62$ & $21.23-22.10$ & 21.66 \\
\hline FO & Pulleniatina primalis & Base N17B/Top N17A & 5.8 & $3 \mathrm{H}-4,123-125$ & $3 \mathrm{H}-5,60-62$ & $22.73-23.60$ & 23.16 \\
\hline FO & Globorotalia plesiotumida & Base N17A/Top N16 & 7.1 & $3 \mathrm{H}-\mathrm{CC}$ & $4 \mathrm{H}-1,126-128$ & $25.70-27.74$ & 26.72 \\
\hline FO & Neogloboquadrina acostaensis & Base N16/Top N15 & 10.2 & $3 \mathrm{H}-\mathrm{CC}$ & $4 \mathrm{H}-1,126-128$ & $25.70-27.74$ & 26.72 \\
\hline LO & Paragloborotalia mayeri & Base N15/Top N14 & 10.4 & $3 \mathrm{H}-\mathrm{CC}$ & $4 \mathrm{H}-1,126-128$ & $25.70-27.74$ & 26.72 \\
\hline FO & Globoturborotalita nepenthes & Base NI4/Top N13 & 11.3 & $3 \mathrm{H}-\mathrm{CC}$ & $4 \mathrm{H}-1,126-128$ & $25.70-27.74$ & 26.72 \\
\hline LO & Fohsella & Base N13/Top N12 & 11.5 & $3 \mathrm{H}-\mathrm{CC}$ & $4 \mathrm{H}-1,126-128$ & $25.70-27,74$ & 26.72 \\
\hline FO & Fohsella robusta & & 12.6 & $5 \mathrm{H}-3,59-61$ & $5 \mathrm{H}-4,59-61$ & $39.59-41.09$ & 40.34 \\
\hline FO & Fohsella fohsi & Base NI2/Top NII & 13.1 & $6 \mathrm{H}-6,60-62$ & $6 \mathrm{H}-\mathrm{CC}$ & $54.20-55.00$ & 54.60 \\
\hline FO & Fohsella praefohsi & Base N11/Top NI0 & 13.9 & $6 \mathrm{H}-6,60-62$ & $6 \mathrm{H}-\mathrm{CC}$ & $54.20-55.00$ & 54.60 \\
\hline LO & Fohsella peripheroronda & & 14.6 & $6 \mathrm{H}-\mathrm{CC}$ & $7 \mathrm{H}-1,59-61$ & $55.00-55.59$ & 55.30 \\
\hline FO & Fohsella peripheroacuta & Base N10/Top N9 & 14.9 & $7 \mathrm{H}-4,59-6 \mathrm{I}$ & $7 \mathrm{H}-5,59-61$ & $60.09-61.59$ & 60.84 \\
\hline FO & Orbulina & Base N9/Top N8 & 15.2 & $7 \mathrm{H}-\mathrm{CC}$ & $8 \mathrm{H}-1,59-61$ & $64.50-65.09$ & 64.80 \\
\hline FO & Praeorbulina circularis & & 16.2 & $8 \mathrm{H}-1,59-61$ & $8 \mathrm{H}-2,59-61$ & $65.09-66.59$ & 65.84 \\
\hline $\mathrm{FO}$ & Praeorbulina glomerosa & & 16.3 & $8 \mathrm{H}-3,59-61$ & $8 \mathrm{H}-4,59-61$ & $68.09-69.59$ & 68.84 \\
\hline $\mathrm{FO}$ & Praeorbulina curva & & 16.5 & $8 \mathrm{H}-\mathrm{CC}$ & $9 \mathrm{H}-1,59-61$ & $74.00-74.59$ & 74.30 \\
\hline FO & Praeorbulina sicana & Base N8/Top N7 & 16.6 & $9 \mathrm{H}-5,59-6 \mathrm{I}$ & $9 \mathrm{H}-\mathrm{CC}$ & $81.80-83.50$ & 82.65 \\
\hline FO & Globigerinatella sp. & Base N6/Top N5 & 19.0 & $\mathrm{I} 3 \mathrm{H}-\mathrm{CC}$ & $14 \mathrm{H}-1,60-62$ & $121.50-122.10$ & 121.80 \\
\hline FO & Globoquadrina dehiscens & & 23.2 & $15 \mathrm{H}-5,59-6 \mathrm{I}$ & $15 \mathrm{H}-6,59-61$ & $137.09-138.59$ & 137.84 \\
\hline $\mathrm{FO}$ & Globigerinoides trilobus & Base N4B/Top N4A & 23.5 & $15 \mathrm{H}-\mathrm{CC}$ & Bottom & $139.20-139.50$ & $>139.20$ \\
\hline
\end{tabular}

Note: $\mathrm{FO}=$ first occurrence and $\mathrm{LO}=$ last occurrence.

Table 3. Coiling measurements on the Pulleniatina lineage, Hole 871A.

\begin{tabular}{|c|c|c|c|c|}
\hline $\begin{array}{l}\text { Core, section, } \\
\text { interval }(\mathrm{cm})\end{array}$ & $\begin{array}{l}\text { Depth } \\
\text { (mbsf) }\end{array}$ & Ratio & $\begin{array}{c}\text { Dextral } \\
(\%)\end{array}$ & $\begin{array}{c}\text { Principal } \\
\text { morphospecies }\end{array}$ \\
\hline \multicolumn{5}{|l|}{ 144-871A- } \\
\hline $1 \mathrm{H}-1,59-61$ & 0.59 & $50: 0$ & 100 & P. obliquiloculata \\
\hline $1 \mathrm{H}-2,59-61$ & 1.99 & $50: 0$ & 100 & P. obliquiloculata \\
\hline IH $-3,59-61$ & 3.49 & $48: 2$ & 96 & P. obliquiloculata \\
\hline $\mid \mathrm{H}-4,59-61$ & 4.99 & $50: 0$ & 100 & P. obliquiloculata \\
\hline $1 \mathrm{H}-5,59-6 \mathrm{I}$ & 6.49 & $49: 1$ & 98 & P. obliquiloculata \\
\hline $\mathrm{IH}-\mathrm{CC}$ & 7.30 & $49: 1$ & 98 & P. obliquiloculata \\
\hline $2 \mathrm{H}-1,60-62$ & 8.09 & $27: 23$ & 54 & P. obliquiloculata \\
\hline $2 \mathrm{H}-2,60-62$ & 9.59 & $38: 12$ & 76 & P. obliquiloculata \\
\hline $2 \mathrm{H}-3,60-62$ & 11.09 & $40: 10$ & 80 & P. obliquiloculata \\
\hline $2 \mathrm{H}-4,60-62$ & 12.59 & $39: 11$ & 78 & P. obliquiloculata \\
\hline $2 \mathrm{H}-5,60-62$ & 14.09 & $21: 29$ & 42 & P. obliquiloculata \\
\hline $2 \mathrm{H}-6,60-52$ & 15.59 & $30: 20$ & 60 & P. obliquiloculata \\
\hline $2 \mathrm{H}-\mathrm{CC}$ & 16.60 & $45: 5$ & 90 & P. obliquiloculata \\
\hline $3 \mathrm{H}-1,60-62$ & 17.60 & $5: 45$ & 10 & $P$ praecursor \\
\hline $3 \mathrm{H}-1,123-125$ & 18.23 & $0: 50$ & 0 & P. praecursor \\
\hline $3 \mathrm{H}-2,60-62$ & 19.10 & $44: 6$ & 88 & P. praecursor \\
\hline $3 \mathrm{H}-2,123-125$ & 19.73 & $40: 10$ & 80 & P. praecursor \\
\hline $3 \mathrm{H}-3,60-62$ & 20.60 & $49: 1$ & 98 & P. praecursor \\
\hline $3 \mathrm{H}-3,123-125$ & 21.23 & $48: 2$ & 96 & P. praecursor \\
\hline $3 \mathrm{H}-4,60-62$ & 22.10 & $7: 43$ & 14 & P. primalis \\
\hline $3 \mathrm{H}-4,123-124$ & 22.73 & $3: 47$ & 6 & $P$. primalis \\
\hline $3 \mathrm{H}-5,60-62$ & 23.60 & $29: 21$ & 58 & N. acostaensis \\
\hline
\end{tabular}

ungulata and other menardiform Globorotalia that could easily be mistaken for the marker species. Because of these difficulties, the presence of true G. plesiotumida cannot be confirmed and the interval from Sample 144-872C-5H-1, 14-16 cm, through $-5 \mathrm{H}-3,14-16 \mathrm{~cm}$, is assigned tentatively to Zone N16 on the basis of the general character of the assemblage.

Frequent reworking occurs in the interval from Samples 144-872C$4 \mathrm{H}-5,59-61 \mathrm{~cm}$, to $-6 \mathrm{H}-1,20-22 \mathrm{~cm}$, and is accompanied by severe fragmentation of tests. Most of the reworked material is apparently from Zones P22 and N4. Paragloborotalia pseudokugleri, P. kugleri, and the "Globigerina" ciperoensis group are the most obvious reworked forms. A few specimens of Globigerinoides bisphericus, Globorotalia mayeri, and Fohsella peripheroacuta indicate a component from Zone N10 and/or Zone N9. A single well-preserved specimen of Dicarinella hagni is present in Sample 144-872C-5H-4, 14-16 cm, and is presumably derived from a pocket of Turonian pelagic sediment on the edge of the guyot (see discussion below). Note that this species was found in chalk infills of cracks in the basalt that underlies the pelagic cap in Hole 872B (Premoli Silva, Haggerty, Rack, et al., 1993).

The first appearance of Neogloboquadrina acostaensis is in Sample 144-872C-5H-3, 14-16 cm, and is used to place the base of Zone N16. Nannofossil evidence suggests a small hiatus at approximately this level in Hole 872A (see Premoli Silva, Haggerty, Rack, et al., 1993). This hiatus accounts for the thinness of Zone N16. Another small hiatus, between Samples 144-872C-5H-CC and -6H-1, 20-22 $\mathrm{cm}$, is identified by the absence of Zone N14 (the co-occurrence of Paragloborotalia mayeri and Globoturborotalita nepenthes).

Zone N13, which is recognized by the absence of both Globoturborotalita nepenthes and Fohsella fohsi, occupies all of Core 144$872 \mathrm{C}-6 \mathrm{H}$ and some of Core $144-872 \mathrm{C}-7 \mathrm{H}$. A consideration of the sedimentation rate curve (Fig. 5) shows that this thickness must represent a significant increase in the sedimentation rate relative to the well-constrained sequence below.

Reworking of sporadic specimens belonging to various stages of the Fohsella lineage occurs a little above the presumed extinction level of that genus, which is placed at Sample 144-872C-7H-4, 20-22 $\mathrm{cm}$. In this sample, Fohsella robusta, F. lobata, and $F$. fohsi are present in abundance, marking the top of Zone N12. Evolutionary stages in the Fohsella chronocline are used to demark Zones N11 and N10. Sample 144-872C-8H-CC contains Fohsella peripheroacuta and Orbulina and so is placed in Zone N10. 
The biostratigraphy of Core $144-872 \mathrm{C}-9 \mathrm{H}$ is complicated by severe reworking and the apparent "age inversion" of the faunas. Fortunately, the rapid evolution of the Praeorbulina-Orbulina lineage in this early to middle Miocene boundary interval permits a high biostratigraphic resolution and allows a detailed investigation of the reworking history. Two samples per section were studied throughout Core 144-872C-9H (not all data are shown). Comparison with Hole $872 \mathrm{~A}$, in which similar mixing can be recognized, argues against downhole contamination as the prime cause of confusion in this case (although a few minor downhole contaminants from the Pleistocene are present in Sample 144-872C-9H-6, 20-22 cm).

Samples 144-872C-9H-1, 20-22 cm, and -9H-1, 95-97 cm, lack Orbulina and Fohsella peripheroacuta but contain frequent Globigerinoides bisphericus and rare Praeorbulina sicana. The more advanced Praeorbulina species are absent, and thus the entire fauna appears to indicate a level toward the bottom of Zone N8. However, in Sample 144-872C-9H-2, 20-22 cm, Praeorbulina is absent and both Orbulina and $F$. peripheroacuta are present in reasonable numbers, which indicates a level in Zone N10. Thus, Section 144-872C$9 \mathrm{H}-1$ is interpreted as containing exclusively reworked sediment. The existence of this same fauna at an equivalent depth in Hole 872A suggests that a large feature such as a sand wave may have been responsible for the apparent age inversion.

Samples 144-872C-9H-3, 20-22 cm, through -9H-6, 78-80 cm, contain Orbulina and $F$. peripheroacuta as well as various representatives of the Praeorbulina morphoseries. These are interpreted as being a mixed assemblage with elements from Zones N9 and N10. Sample 144-872C-9H-7, 20-22 cm, and other samples below it contain an assemblage similar to the top sample of the core, lacking Orbulina and the advanced members of the Praeorbulina group; therefore, they can be placed in the lower part of Zone N8 with confidence. It is evident that a small hiatus spanning the top part of Zone N8 exists between Samples 144-872C-9H-6, 20-22 cm, and $-9 \mathrm{H}-7,20-22 \mathrm{~cm}$, at the bottom of the interval of severe reworking. Zone N8 is present down to Sample 144-872C-10H-CC, where the first appearance of Praeorbulina sicana is recorded.

Biostratigraphic assignment within the Zone N5-N7 interval is problematic because both key zonal markers (Globigerinatella sp. and Catapsydrax dissimilis) are very rare at Site 872 and other species that might help characterize the interval are found reworked up core. Rare specimens of Globigerinatella sp. are found down to Sample 144-872C-12H-1, 20-22 cm. This sample is assigned to Zone N6/N7. The top of Zone N4 is marked by the LO of Paragloborotalia kugleri, which occurs in Sample 144-872C-13H-4, 20-22 cm.

The upper Oligocene (Zone P22 to Subzone N4a) was recovered in Cores 144-872C-14H to -17X. Upper Oligocene pelagic sediment was the first to accumulate at this site following drowning of the edifice. The sequence is strongly affected by reworking. Fragmentation of the tests varies from light to severe.

Particularly striking is the reworking of diverse middle and upper Eocene elements in Cores 144-872A-14H and $-15 \mathrm{H}$. The following taxa were recognized: Acarinina bullbrooki, Acarinina collactea, Acarinina topilensis, Globigerinatheka subconglobata, Subbotina eocaena, and Hantkenina alabamensis. Reworked Pseudohastigerina micra in Sample 144-872C-17X-CC may also have been derived from the Eocene or from the lower Oligocene. The preservation of these reworked individuals is generally very good, although a few are badly stained by iron. This fauna indicates the survival of pockets of Eocene pelagic ooze on the guyot edge that were subsequently reworked onto the central area of the pelagic cap.

More problematic for biostratigraphic assignment is the largescale upward mixing of lower and mid-Oligocene elements, which was observed in Cores $144-872 \mathrm{C}-16 \mathrm{H}$ and $-17 \mathrm{X}$. In particular, the important zonal fossils Chiloguembelina cubensis and Paragloborotalia opima are frequently found in these cores in association with younger species typical of Zone P22 and above. It may be that a significant portion of the sediment in this interval near the base of the pelagic cap was derived from older sediment, which was subsequently thoroughly reworked into younger deposits.

Several zonal criteria for the upper Oligocene and lower Miocene utilize last occurrences of taxa. However, because of the significant mixing of sediment of different ages, biostratigraphic age assignments in this study are more confidently based on first occurrences than on last occurrences. Some last occurrence datums are estimated by the observed sharp drops in abundance of those species. First occurrences of the following species are of particular use in the upper Oligocene to lower Miocene age interval: Paragloborotalia pseudokugleri, "Globigerinoides" primordius, Paragloborotalia kugleri s.str., Globoquadrina dehiscens, and Globigerinoides trilobus s.1. (see discussion of Zones P22 and N4 above). The FO of Paragloborotalia kugleri (marking the base of Zone N4) is in Sample 144-872C-14HCC. The first appearance of Globigerinoides trilobus s.I. is a little above this in Sample 144-872C-14H-6, 20-22 cm. This is still considerably below the first appearance of typical Globoquadrina dehiscens in Sample 144-872C-13H-5, 20-22 cm.

Samples at the bottom of the pelagic cap in Core 144-872C-17X contain both Paragloborotalia pseudokugleri and "Globigerinoides" primordius but no $P$. kugleri. This apparently indicates that at least some of the sediment belongs to Zone P22, possibly the upper part of the zone. However, both Paragloborotalia opima and Chiloguembelina cubensis are frequent, indicating a component of sediment from at least Subzones P21a and/or P21b, and possibly also Zone P20. In addition, rare Pseudohastigerina micra in Sample 144-872C-17X$\mathrm{CC}$ may indicate a small Eocene or lower Oligocene component to the sediment. It is difficult to establish the proportions of the various components present because most of the dominant taxa range throughout the time interval in question.

For most of Core $144-872 \mathrm{C}-16 \mathrm{H}$, the fauna is similar to Core 144-872C-17X except that both Paragloborotalia pseudokugleri and "Globigerinoides" primordius are either absent or extremely rare. Thus, Core 144-872C-16X appears to have been taken from a packet of slightly older sediment (assignable to Subzones P21a and/or P21b) than that found in Core 144-872C-17X. Alternatively, major caving of sediment associated with the introduction of the extended core barrel may have been responsible for the apparent "age inversion."

\section{Wodejebato Guyot (Site 873)}

Wodejebato Guyot lies in the central part of the Ralik Chain of seamounts, a little to the north of Pikkini Atoll, which shares the same volcanic ridge (see Fig. 1). Site $873\left(11^{\circ} 53.796^{\prime} \mathrm{N}, 16^{\circ} 55.188^{\prime} \mathrm{E}\right.$ ) was drilled off-center of the pelagic cap and so may not have recovered the oldest sediments present. The pelagic cap was recovered by APC drilling in Hole 873B, to a depth of $69 \mathrm{~m}$ below seafloor (mbsf) with $78 \%$ recovery. The lithology is foraminifer ooze except for the top $\sim 25 \mathrm{~m}$, which is nannofossil-foraminifer ooze (Premoli Silva, Haggerty, Rack, et al., 1993). Planktonic foraminifers are very abundant and moderately well preserved, showing few signs of dissolution or diagenetic recrystallization but frequent evidence of mechanical damage. Fragmentation is mostly severe to very severe throughout the hole, generally worse than at Sites 871 and 872 . As was the case for Sites 871 and 872 , the sediment was found to be very soft and unconsolidated throughout the pelagic cap. Ranges of planktonic foraminifer species are shown in Table 7, and a list of the principal datums is given in Table 8. These datums were used to construct the sedimentation rate curve given in Figure 7. Reworking complicates the biostratigraphy of the site, particularly in Cores $144-873 \mathrm{~B}-5 \mathrm{H}$ and $-6 \mathrm{H}$.

Zone N22 is thin in Hole 873B, present only from the surface down to Sample 144-873B-1H-4, 36-38 cm. The highest sample analyzed (144-873B-1H-1,36-38 cm) contains pink Globigerinoides ruber and the extinct species Globorotalia tosaensis, indicating an age in excess of $0.6 \mathrm{Ma}$. Pulleniatina finalis is present down to Sample 144-873B-1H-3, 36-38 cm. This morphospecies supposedly appeared at $1.3 \mathrm{Ma}$, but the datum may be unreliable, particularly as 
Table 4. Stratigraphic ranges of planktonic foraminifers in Hole $872 \mathrm{C}$.

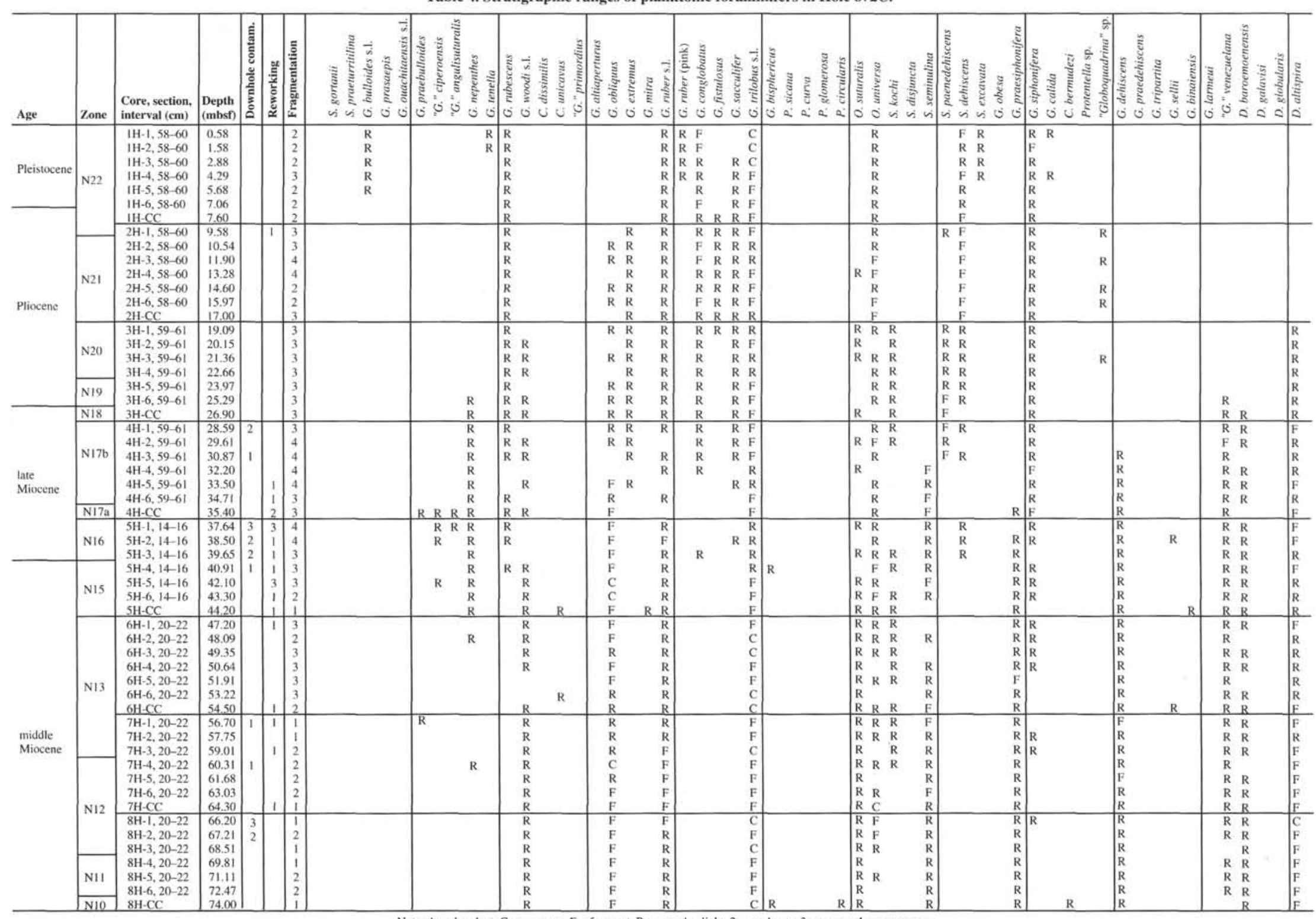

Note: $\mathrm{A}=$ abundant, $\mathrm{C}=$ common, $\mathrm{F}=$ frequent $\mathrm{R}=\mathrm{rare}, \mathrm{I}=$ light, $2=$ moderate, $3=$ severe, $4=$ very severe. 
Table 4 (continued).

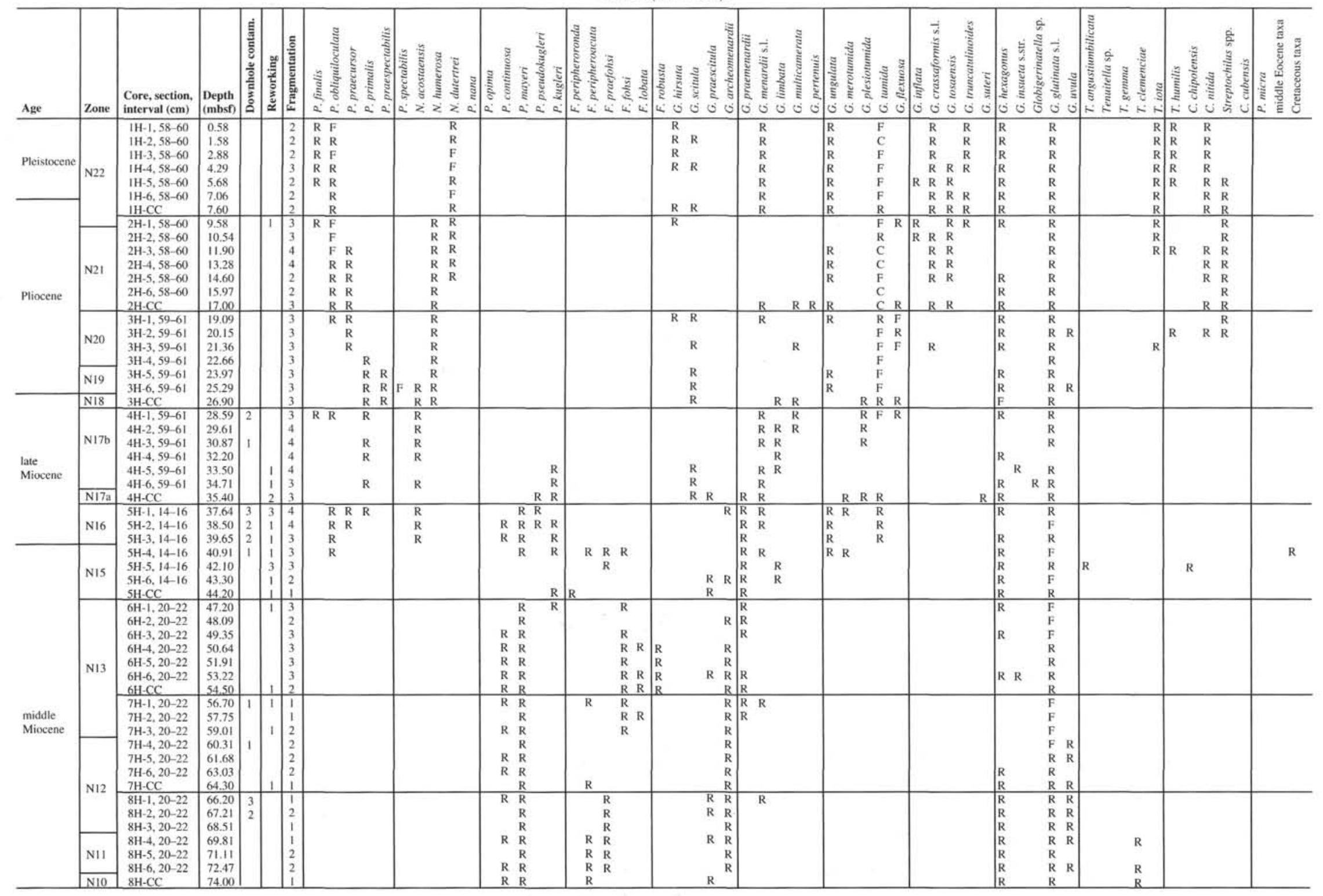




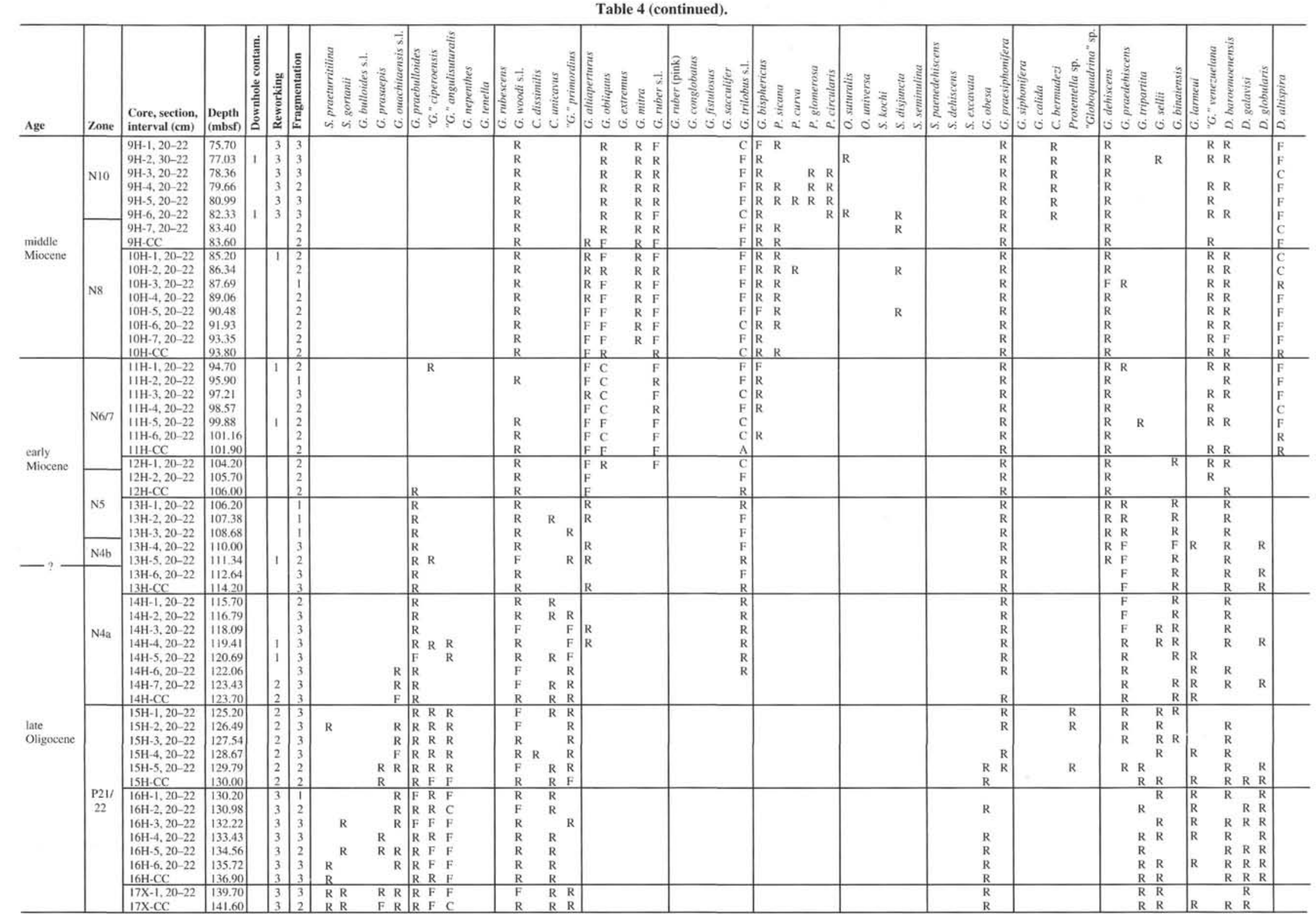


Table 4 (continued).

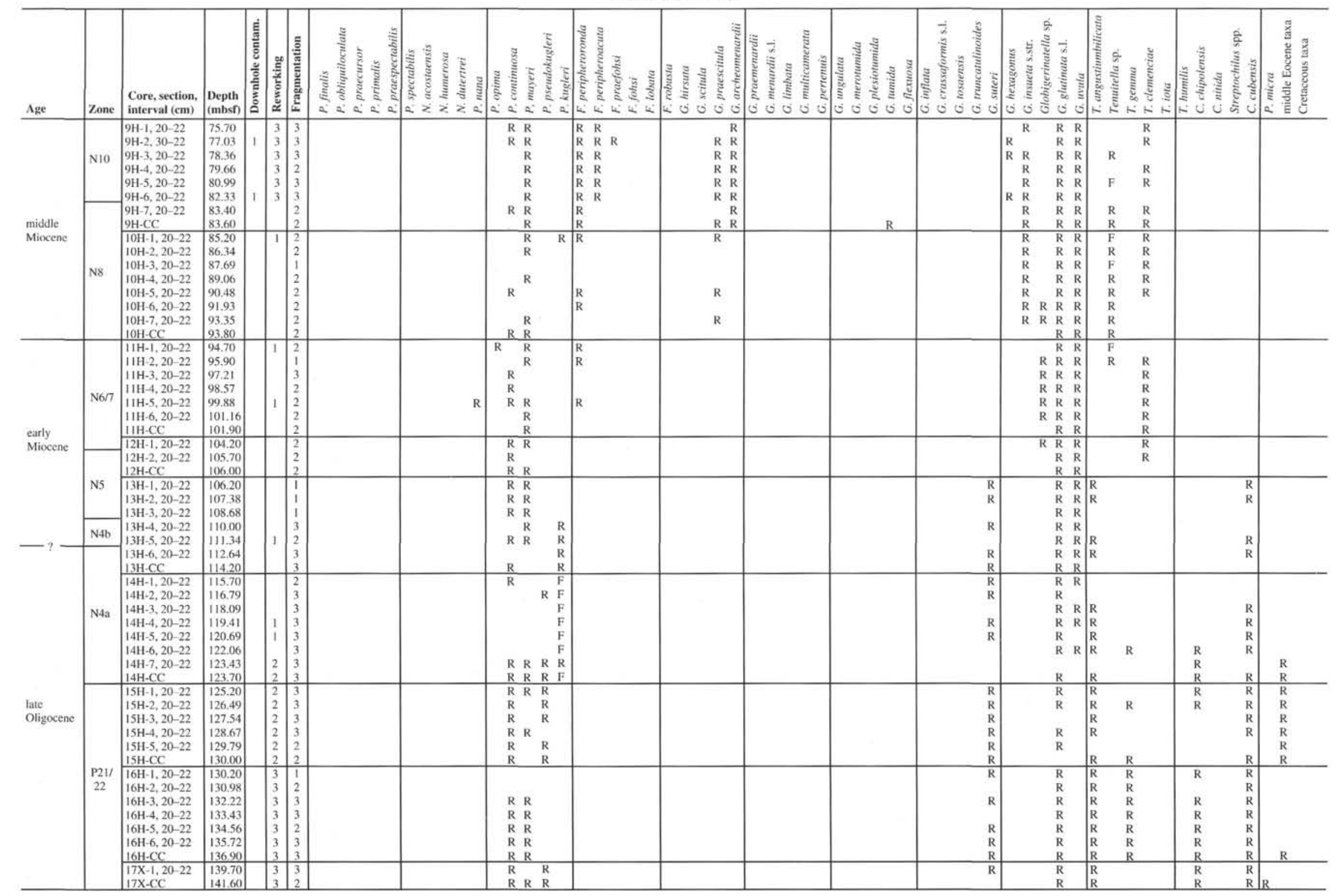


Table 5. Planktonic foraminifer datums in Hole $872 \mathrm{C}$ and their stratigraphic positions.

\begin{tabular}{|c|c|c|c|c|c|c|c|}
\hline \multirow[b]{2}{*}{ Datum } & & \multirow{2}{*}{$\begin{array}{l}\text { Stratigraphic } \\
\text { position }\end{array}$} & \multirow{2}{*}{$\begin{array}{l}\text { Age } \\
\text { (Ma) }\end{array}$} & \multicolumn{2}{|c|}{ Core, section, interval $(\mathrm{cm})$} & \multirow{2}{*}{$\begin{array}{l}\text { Depth } \\
\text { (mbsf) }\end{array}$} & \multirow{2}{*}{$\begin{array}{c}\text { Interpolated } \\
\text { depth } \\
\text { (mbsf) }\end{array}$} \\
\hline & & & & Top & Bottom & & \\
\hline LO & Pink Globigerinoides nuber & \multirow{6}{*}{ Pliocene/Pleistocene } & 0.12 & Core top & $1 \mathrm{H}-1,58-60$ & $0.0-0.58$ & $<0.58$ \\
\hline LO & Globorotalia tosaensis & & 0.6 & $1 \mathrm{H}-3,124-126$ & $1 \mathrm{H}-4,58-60$ & $3.52-4.29$ & 3.90 \\
\hline & Pulleniatina, last coiling reversal & & 0.8 & $1 \mathrm{H}-3,124-126$ & $1 \mathrm{H}-4,58-60$ & $3.52-4.29$ & 3.90 \\
\hline FO & Pulleniatina finalis & & 1.3 & $2 \mathrm{H}-1,58-60$ & $2 \mathrm{H}-2,58-60$ & $9.58-10.54$ & 10.06 \\
\hline LO & Globigerinoides fistulosus & & 1.6 & $\mathrm{IH}-6,58-60$ & $\mathrm{IH}-\mathrm{CC}$ & $7.06-7.60$ & 7.33 \\
\hline LO & Globigerinoides extremus & & 1.8 & $\mathrm{IH}-\mathrm{CC}$ & $2 \mathrm{H}-1,58-60$ & $7.60-9.58$ & 8.59 \\
\hline FO & Globorotalia truncatulinoides & \multirow[t]{4}{*}{ Base N22/Top N21 } & 1.9 & $2 \mathrm{H}-1,58-60$ & $2 \mathrm{H}-2,58-60$ & $9.58-10.54$ & 10.06 \\
\hline LO & Dentoglobigerina altispira & & 2.9 & $2 \mathrm{H}-\mathrm{CC}$ & $3 \mathrm{H}-1,59-61$ & $17.00-19.09$ & 18.04 \\
\hline $\mathrm{FO}$ & Globigerinoides fistulosus & & 2.9 & $3 \mathrm{H}-1,59-61$ & $3 \mathrm{H}-2,59-61$ & $19.09-20.15$ & 19.62 \\
\hline LO & Sphaerodinellopsis & & 3.0 & $2 \mathrm{H}-\mathrm{CC}$ & $3 \mathrm{H}-1,59-61$ & $17.00-19.09$ & 18.04 \\
\hline FO & Globorotalia tosaensis & \multirow{2}{*}{ Base N21/Top N20 } & 3.1 & $2 \mathrm{H}-\mathrm{CC}$ & $3 \mathrm{H}-1,59-61$ & $17.00-19.09$ & 18.04 \\
\hline LO & Pulleniatina primalis & & 3.5 & $3 \mathrm{H}-4,59-61$ & $3 \mathrm{H}-4,118-120$ & $22.66-23.25$ & 22.95 \\
\hline & Pulleniatina, first coiling reversal & \multirow{3}{*}{ Base N20/Top NI9 } & 3.8 & $3 \mathrm{H}-4,118-120$ & $3 \mathrm{H}-5,59-61$ & $23.25-23.97$ & 23.61 \\
\hline LO & Pulleniatina spectabilis & & 3.9 & $3 \mathrm{H}-5,59-6 \mathrm{I}$ & $3 \mathrm{H}-5,118-120$ & $23.97-24.56$ & 24.26 \\
\hline LO & Globoturborotalita nepenthes & & 3.9 & $3 \mathrm{H}-5,118-120$ & $3 \mathrm{H}-6,59-61$ & $24.56-25.29$ & 24.92 \\
\hline FO & Sphaeroidinella dehiscens & \multirow[t]{2}{*}{ Base N19/Top N18 } & 5.1 & $3 \mathrm{H}-6,59-61$ & $3 \mathrm{H}-\mathrm{CC}$ & $25.29-26.90$ & 26.10 \\
\hline FO & Pulleniatina spectabilis & & 5.2 & $3 \mathrm{H}-6,59-6 \mathrm{I}$ & $3 \mathrm{H}-\mathrm{CC}$ & $25.29-26.90$ & 26.10 \\
\hline FO & Globorotalia tumida & \multirow[t]{3}{*}{ Base N18/Top N17B } & 5.2 & $3 \mathrm{H}-\mathrm{CC}$ & $4 \mathrm{H}-1,59-61$ & $26.90-28.59$ & 27.74 \\
\hline $\mathrm{FO}$ & Globigerinoides conglobatus & & 5.3 & $4 \mathrm{H}-3,59-61$ & $4 \mathrm{H}-4,59-61$ & $30.87-32.20$ & 31.54 \\
\hline LO & Globoquadrina dehiscens & & 5.3 & $4 \mathrm{H}-3,59-6 \mathrm{I}$ & $4 \mathrm{H}-4,59-61$ & $30.87-32.20$ & 31.54 \\
\hline $\mathrm{FO}$ & Pulleniatina primalis & Base N17B/Top N17A & 5.8 & $4 \mathrm{H}-6,59-6 \mathrm{I}$ & $4 \mathrm{H}-\mathrm{CC}$ & $34.71-35.30$ & 35.06 \\
\hline FO & Globorotalia plesiotumida & Base N17A/Top N16 & 7.1 & $4 \mathrm{H}-\mathrm{CC}$ & $5 \mathrm{H}-1,14-16$ & $35.40-37.64$ & 36.52 \\
\hline FO & Neogloboquadrina acostaensis & Base N16/Top N15 & 10.2 & $5 \mathrm{H}-3,14-16$ & $5 \mathrm{H}-4,14-16$ & $39.65-40.91$ & 40.28 \\
\hline LO & Paragloborotalia mayeri & Base N15/Top N14 & 10.4 & $5 \mathrm{H}-\mathrm{CC}$ & $6 \mathrm{H}-\mathrm{I}, 20-22$ & $44.20-47.20$ & 45.70 \\
\hline $\mathrm{FO}$ & Globoturborotalita nepenthes & Base N14/Top N13 & 11.3 & $5 \mathrm{H}-\mathrm{CC}$ & $6 \mathrm{H}-1,20-22$ & $44.20-47.20$ & 45.70 \\
\hline LO & Fohsella & \multirow[t]{2}{*}{ Base N13/Top NI2 } & 11.5 & $7 \mathrm{H}-3,20-22$ & $7 \mathrm{H}-4,20-22$ & $59.01-60.31$ & 59.66 \\
\hline FO & Fohsella robusta & & 12.6 & $7 \mathrm{H}-\mathrm{CC}$ & $8 \mathrm{H}-1,20-22$ & $64.30-66.20$ & 65.25 \\
\hline $\mathrm{FO}$ & Fohsella fohsi & Base N12/Top NII & 13.1 & $8 \mathrm{H}-3,20-22$ & $8 \mathrm{H}-4,20-22$ & $68.51-69.81$ & 69.16 \\
\hline FO & Fohsella praefohsi & \multirow[t]{2}{*}{ Base N11/Top NIO } & 13.9 & $8 \mathrm{H}-6,20-22$ & $8 \mathrm{H}-\mathrm{CC}$ & $72.47-74.00$ & 73.24 \\
\hline LO & Fohsella peripheroronda & & 14.6 & $8 \mathrm{H}-\mathrm{CC}$ & $9 \mathrm{H}-1,20-22$ & $74.00-75.70$ & 74.85 \\
\hline FO & Fohsella peripheroacuta & Base N10/Top N9 & 14.9 & $9 \mathrm{H}-6,20-22$ & $9 \mathrm{H}-7,20-22$ & $82.33-83.40$ & 82.86 \\
\hline FO & Orbulina & \multirow[t]{2}{*}{ Base N9/Top N8 } & 15.2 & $9 \mathrm{H}-6,20-22$ & $9 \mathrm{H}-7,20-22$ & $82.33-83.40$ & 82.86 \\
\hline FO & Praeorbulina circularis & & 16.2 & $9 \mathrm{H}-6,20-22$ & $9 \mathrm{H}-7,20-22$ & $82.33-83.40$ & 82.86 \\
\hline FO & Praeorbulina sicana & Base N8/Top N7 & 16.6 & $10 \mathrm{H}-\mathrm{CC}$ & $11 \mathrm{H}-1,20-22$ & $93.80-94.70$ & 94.25 \\
\hline FO & Globigerinatella sp. & Base N6/Top N5 & 19.0 & $12 \mathrm{H}-1,20-22$ & $12 \mathrm{H}-2,20-22$ & $104.20-105.70$ & 104.95 \\
\hline LO & Paragloborotalia kugleri & \multirow[t]{2}{*}{ Base N5/Top N4B } & 21.8 & $13 \mathrm{H}-3,20-22$ & $13 \mathrm{H}-4,20-22$ & $108.68-110.00$ & 109.34 \\
\hline LO & Dentoglobigerina globularis & & 22.8 & $13 \mathrm{H}-4,20-22$ & $13 \mathrm{H}-5,20-22$ & $110.00-111.34$ & 110.67 \\
\hline FO & Globoquadrina dehiscens & \multirow[t]{3}{*}{ Base N4B/Top N4A } & 23.2 & $13 \mathrm{H}-5,20-22$ & $13 \mathrm{H}-6,20-22$ & $111.34-112.64$ & 111.99 \\
\hline LO & Paragloborotalia pseudokugleri & & 23.2 & $13 \mathrm{H}-5,20-22$ & $13 \mathrm{H}-6,20-22$ & $111.34-112.64$ & 111.99 \\
\hline LO & "Globigerina" angulisuturalis & & 23.2 & $14 \mathrm{H}-\mathrm{CC}$ & $15 \mathrm{H}-1,20-22$ & $123.70-125.20$ & 124.45 \\
\hline FO & Paragloborotalia kugleri & \multirow[t]{2}{*}{ Base N4A/Top P22 } & 23.7 & $14 \mathrm{H}-\mathrm{CC}$ & $15 \mathrm{H}-1,20-22$ & $123.70-125.20$ & 124.45 \\
\hline FO & "G." primordius (common) & & 24.3 & $17 \mathrm{X}-\mathrm{CC}$ & Bottom & $141.60-141.70$ & $>141.60$ \\
\hline
\end{tabular}

Note: $\mathrm{FO}=$ first occurrence and $\mathrm{LO}=$ last occurrence.

Table 6. Coiling measurements on the Pulleniatina lineage, Hole 872C.

\begin{tabular}{|c|c|c|c|c|}
\hline $\begin{array}{l}\text { Core, section } \\
\text { interval }(\mathrm{cm})\end{array}$ & $\begin{array}{l}\text { Depth } \\
\text { (mbsf) }\end{array}$ & Ratio & $\begin{array}{c}\text { Dextral } \\
(\%)\end{array}$ & $\begin{array}{c}\text { Principal } \\
\text { morphospecies }\end{array}$ \\
\hline \multicolumn{5}{|l|}{$144-872 \mathrm{C}-$} \\
\hline $1 \mathrm{H}-1,58-60$ & 0.58 & $50: 0$ & 100 & P. obliquiloculata \\
\hline $1 \mathrm{H}-2,58-60$ & 1.58 & $50: 0$ & 100 & P. obliquiloculata \\
\hline $1 \mathrm{H}-3,58-60$ & 2.88 & $48: 2$ & 96 & $P$, obliquiloculata \\
\hline $1 \mathrm{H}-3,122-124$ & 3.52 & $49: 1$ & 98 & P, obliquiloculata \\
\hline IH $-4,58-60$ & 4.93 & $31: 19$ & 62 & P. obliquiloculata \\
\hline $1 \mathrm{H}-5,58-60$ & 6.32 & $40: 10$ & 80 & P. obliquiloculata \\
\hline $1 \mathrm{H}-6,58-60$ & 7.06 & $14: 36$ & 28 & P. obliquiloculata \\
\hline 1H-CC & 9.00 & $16: 34$ & 32 & P. obbliquiloculata \\
\hline $2 \mathrm{H}-1,58-60$ & 9.58 & $33: 17$ & 66 & P. obliquiloculata \\
\hline $2 \mathrm{H}-2.58-60$ & 10.54 & $2: 48$ & 4 & P. obliquiloculata \\
\hline $2 \mathrm{H}-3,58-60$ & 11.90 & $41: 9$ & 82 & P. obliquiloculata \\
\hline $2 \mathrm{H}-4,58-60$ & 13.28 & $8: 42$ & 16 & P. praecursor \\
\hline $2 \mathrm{H}-5,58-60$ & 14.60 & $23: 27$ & 46 & P. praecursor \\
\hline $2 \mathrm{H}-6,58-60$ & 15.97 & $23: 27$ & 46 & P. praecursor \\
\hline $2 \mathrm{H}-\mathrm{CC}$ & 18.50 & $50: 0$ & 100 & P. praecursor \\
\hline $3 \mathrm{H}-1,59-61$ & 19.09 & $45: 5$ & 90 & P. praecursor \\
\hline $3 \mathrm{H}-2,59-61$ & 20.15 & $49: 1$ & 98 & $P$ praecursor \\
\hline $3 \mathrm{H}-3,59-61$ & 21.36 & $47: 3$ & 94 & P. praecursor \\
\hline $3 \mathrm{H}-4,59-61$ & 22.66 & $46: 4$ & 92 & P. praecursor \\
\hline $3 \mathrm{H}-4,118-120$ & 23.25 & $41: 9$ & 82 & P. praecursor \\
\hline $3 \mathrm{H}-5,59-61$ & 23.97 & $0: 50$ & 0 & $P$. primalis \\
\hline $3 \mathrm{H}-5,118-120$ & 24.56 & $0: 50$ & 0 & P. primalis \\
\hline $3 \mathrm{H}-6,59-61$ & 25.29 & $0: 50$ & 0 & P. spectabilis \\
\hline $3 \mathrm{H}-6,59-61$ & 25.29 & $0: 50$ & 0 & P. primalis \\
\hline $3 \mathrm{H}-6,120-122$ & 25.90 & $0: 50$ & 0 & P. praespectabilis \\
\hline $3 \mathrm{H}-\mathrm{CC}$ & 28.00 & $0: 50$ & 0 & $P$. primalis \\
\hline $4 \mathrm{H}-1,59-61$ & 28.59 & $0: 50$ & 0 & P. primalis \\
\hline $4 \mathrm{H}-2,59-61$ & 29.61 & $1: 49$ & 2 & P. primalis \\
\hline $4 \mathrm{H}-3,59-61$ & 30.87 & $0: 50$ & 0 & P. primalis \\
\hline $4 \mathrm{H}-4.59-6 \mathrm{I}$ & 32.20 & $1: 49$ & 2 & P. primalis \\
\hline
\end{tabular}

nannofossil evidence shows that the topmost sediments belong to the $H$. sellii Zone, which correlates to a slightly lower level within planktonic foraminifer Zone N22. Measurements of the coiling direction in Pulleniatina (Fig. 8 and Table 9) show that the lineage is dextrally dominated in Samples 144-873B-1H-1, 36-38 cm, and -1H-1, 96-98 $\mathrm{cm}$, but mixed in Sample 144-873B-1H-2, 36-38 cm. This coiling event is probably not Saito's (1976) "L1" event but an older coiling oscillation such as "L3."

Sample 144-873B-1H-4, 36-38 cm, contains abundant Globigerinoides fistulosus, in addition to rare Globorotalia truncatulinoides, but no Globigerinoides extremus. This indicates the lower part of Zone N22 and a latest Pliocene age.

Globorotalia tosaensis is extremely scarce at this site, making the identification of the base of Zone N21 (recognized by the first appearance of $G$. tosaensis) problematic. Three specimens of $G$. tosaensis were found in Sample 144-873B-2H-2, 36-38 cm, and none below. However, Globigerinoides fistulosus, which first evolved a little after G. tosaensis, occurs down to Sample $144-873 \mathrm{~B}-2 \mathrm{H}-4,36-38 \mathrm{~cm}$. An assignment to Zone N21 would also be supported by the last occurrence datum of "Dentoglobigerina" altispira, which also occurs at this level. Poorly developed fistulose individuals referable to Globigerinoides fistulosus are also present in Sample 144-873B-2H-5, $36-38 \mathrm{~cm}$

The initial coiling oscillation in the Pulleniatina lineage, which is a shift away from sinistral dominance (Saito's [1976] "L9" event), occurs between Samples 144-873B-3H-2, 36-38 cm, and -3H-2, 94-96 cm, and is used to subdivide Zones N19 and N20. The base of Zone N19 is marked by the appearance of Sphaeroidinella dehiscens in Sample 144-873B-3H-6, 36-38 cm. Note, however, that individu- 


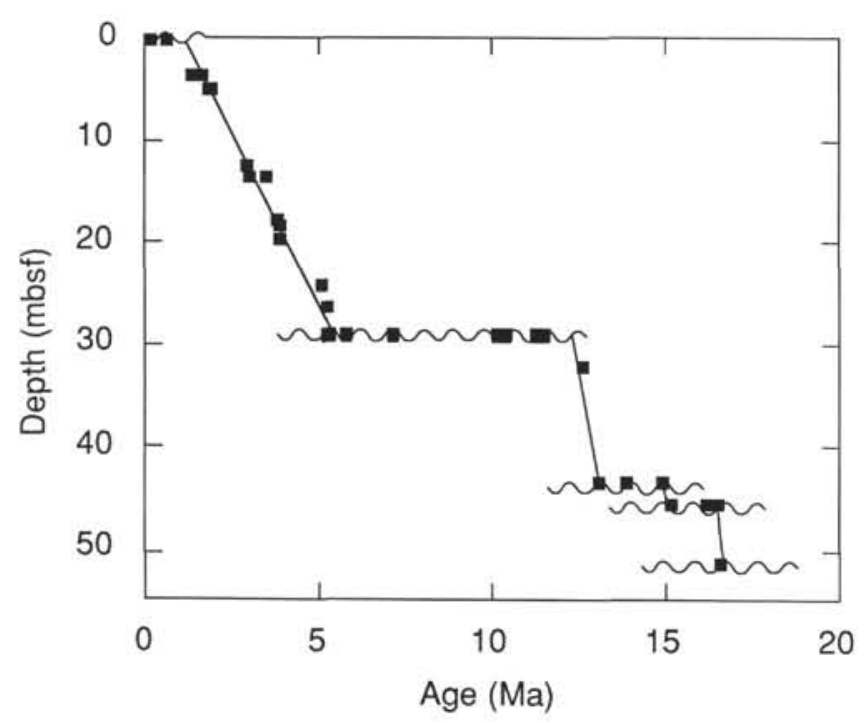

Figure 7. Sediment accumulation curve for the pelagic cap of Wodejebato Guyot (Hole 873B). Squares represent planktonic foraminifer datums listed in Table 8.

als of this taxon are frequent in samples near the top of Core 144$873 \mathrm{~B}-4 \mathrm{H}$, but they have been interpreted as downhole contaminants. Many other contaminants are also present at that level.

A major hiatus is identified between Samples 144-873B-4H-3, $96-98 \mathrm{~cm}$, and $-4 \mathrm{H}-4,36-38 \mathrm{~cm}$. In the latter sample, specimens belonging to the Fohsella lineage are present. Advanced forms ( $F$. fohsi, $F$. robusta, and $F$. lobata) indicate that the youngest component of the sediment belongs to Zone N12. The presence of Fohsella fohsi in samples throughout Core 144-873B-5H indicates Zone N12.

Downhole caving is once again responsible for Pleistocene contaminants near the top of Core 144-873B-5H. However, also present is a significant component of reworked material. The earlier stages of the Fohsella lineage ( $F$. peripheroronda and $F$. peripheroacuta) are intermittently present up to the hiatus level in Core 144-873B-4H, as are Globigerinatella spp. Thus, a sediment component from Zones $\mathrm{N} 10$ and N11 or lower can be recognized. Also present continuously are Globigerinoides bisphericus and Praeorbulina spp., which are restricted to Zone N8. Catapsydrax spp. are rare, which must be derived from sediments as low as Zone N6. Two specimens of Globoquadrina binaiensis, in Cores 144-873B-5H and $-6 \mathrm{H}$, are from Zone N5 or below. Thus, reworking of sediment from most or all of Zones N5 to N12/13 is suggested in this severely mixed interval.

The Fohsella group is absent from all of Core 144-873B-6H, with the exception of $F$. peripheroronda. Also absent is Orbulina, except for rare O. suturalis in Sample 144-872C-6H-1, 36-38 cm, which occurs with the full range of Praeorbulina morphotypes. This sample is attributable to the bottom part of Zone N9. The remainder of the core is placed low in Zone N8 because of the absence of advanced Praeorbulina. Thus, a brief hiatus can be inferred to occur between Samples $144-872 \mathrm{C}-6 \mathrm{H}-1,36-38 \mathrm{~cm}$, and $-6 \mathrm{H}-2,36-38 \mathrm{~cm}$. Severe reworking was also found throughout this core.

\section{SEDIMENT ACCUMULATION AND REWORKING}

\section{Comparisons Among Guyots}

Although significant differences exist in the timing and mode of pelagic cap growth observed at the three guyots, the similarities are striking. The stratigraphies of the three sections, deduced from planktonic foraminifer biostratigraphy, are compared in Figure 9. In each case, there is an initial hiatus after platform drowning, followed by a phase of very mixed sediment accumulation, and finally by a phase of more "normal" sedimentation, but with reworking, fragmentation,
Dextral coiling (\%)

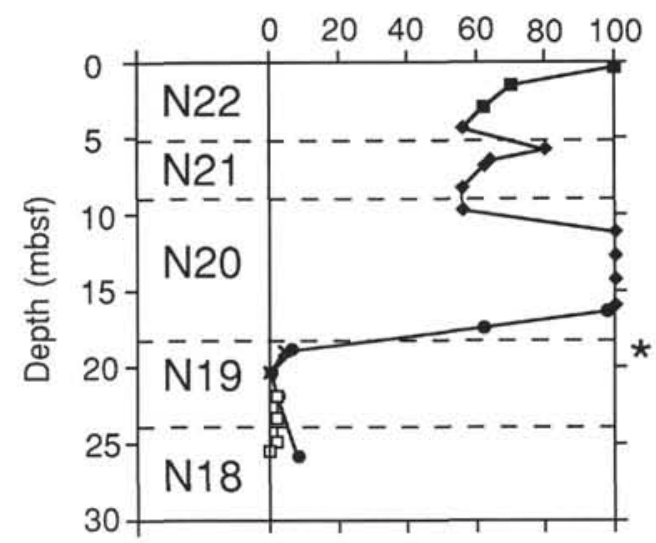

Figure 8. Coiling ratios of Pulleniatina from Wodejebato Guyot (Hole 873B), Each measurement was made on an examination of 50 specimens. Data are presented in Table 9. Asterisk marks the datums used for correlation in this study (see text). Circles $=$ Pulleniatina primalis, diamonds $=$ Pulleniatina praecursor, solid squares $=$ Pulleniatina obliquiloculata , open squares $=$ Pulleniatina praespectabilis, and crosses = Pulleniatina spectabilis.

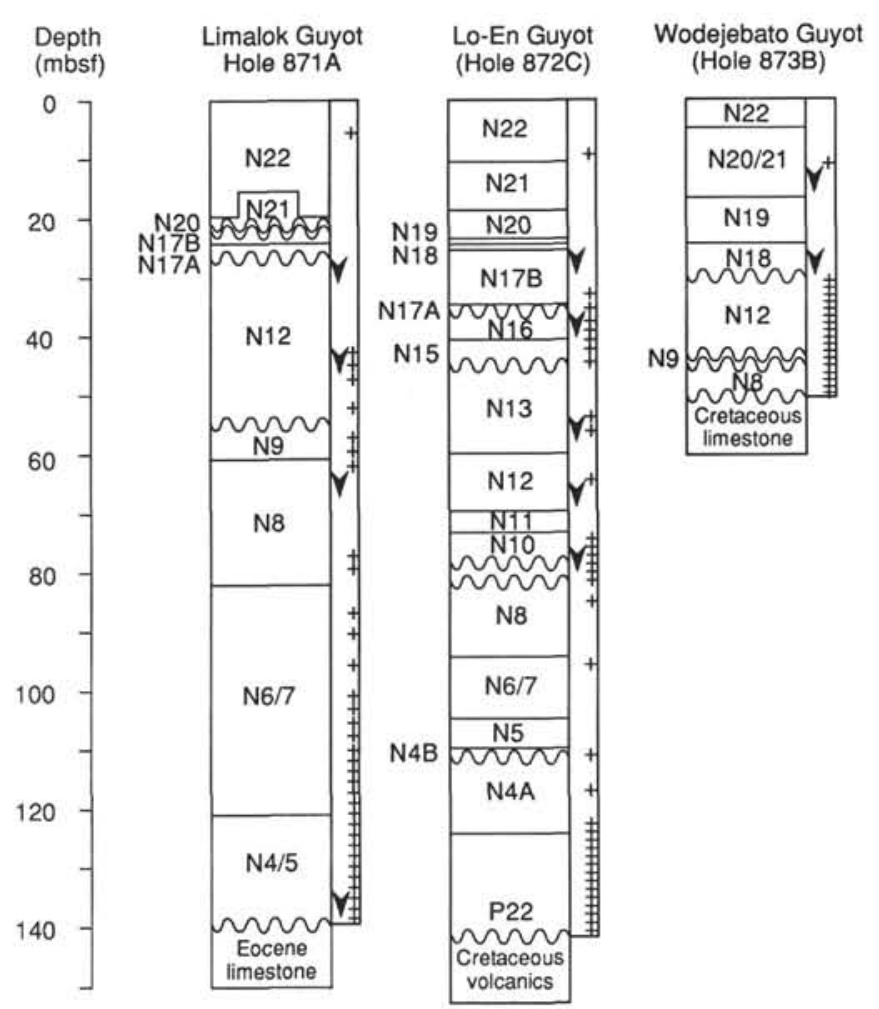

Figure 9. Biostratigraphic summary columns for the three pelagic caps in this study. Arrowheads indicate levels at which downhole contamination was observed. Plus signs indicate levels that show reworking.

and the creation of unconformities. These stages (or phases) are summarized in the sketch in Figure 10.

The initial hiatus (Fig. 10A) presumably represents the time taken for gradual subsidence to take the hard rock surface to depths with suitably low-energy conditions for unconsolidated sediment to accumulate. During this phase, pelagic ooze must have been swept away from exposed surfaces by storm, tidal, and bottom currents. Such conditions were ideal for the formation of phosphatized or manganese 
Table 7. Stratigraphic ranges of planktonic foraminifers in Hole 873B.

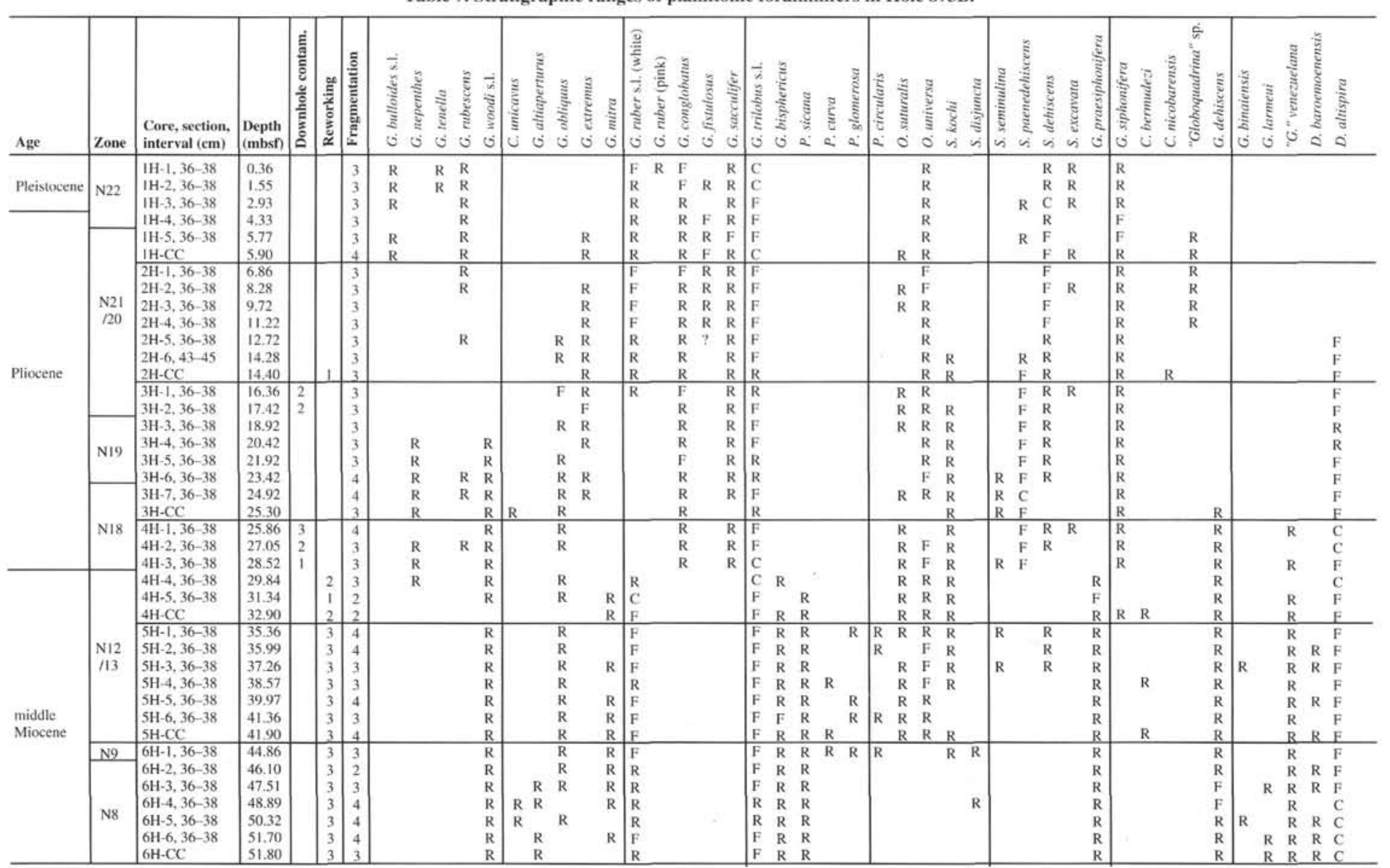

Note: $\mathrm{A}=$ ahundant $\mathrm{C}=$ common, $\mathrm{F}=$ frequent, $\mathrm{R}=$ rare, $\mathrm{I}=$ light, 2 = moderate, $3=$ severe, $4=$ very severe. 
Table 7 (continued).

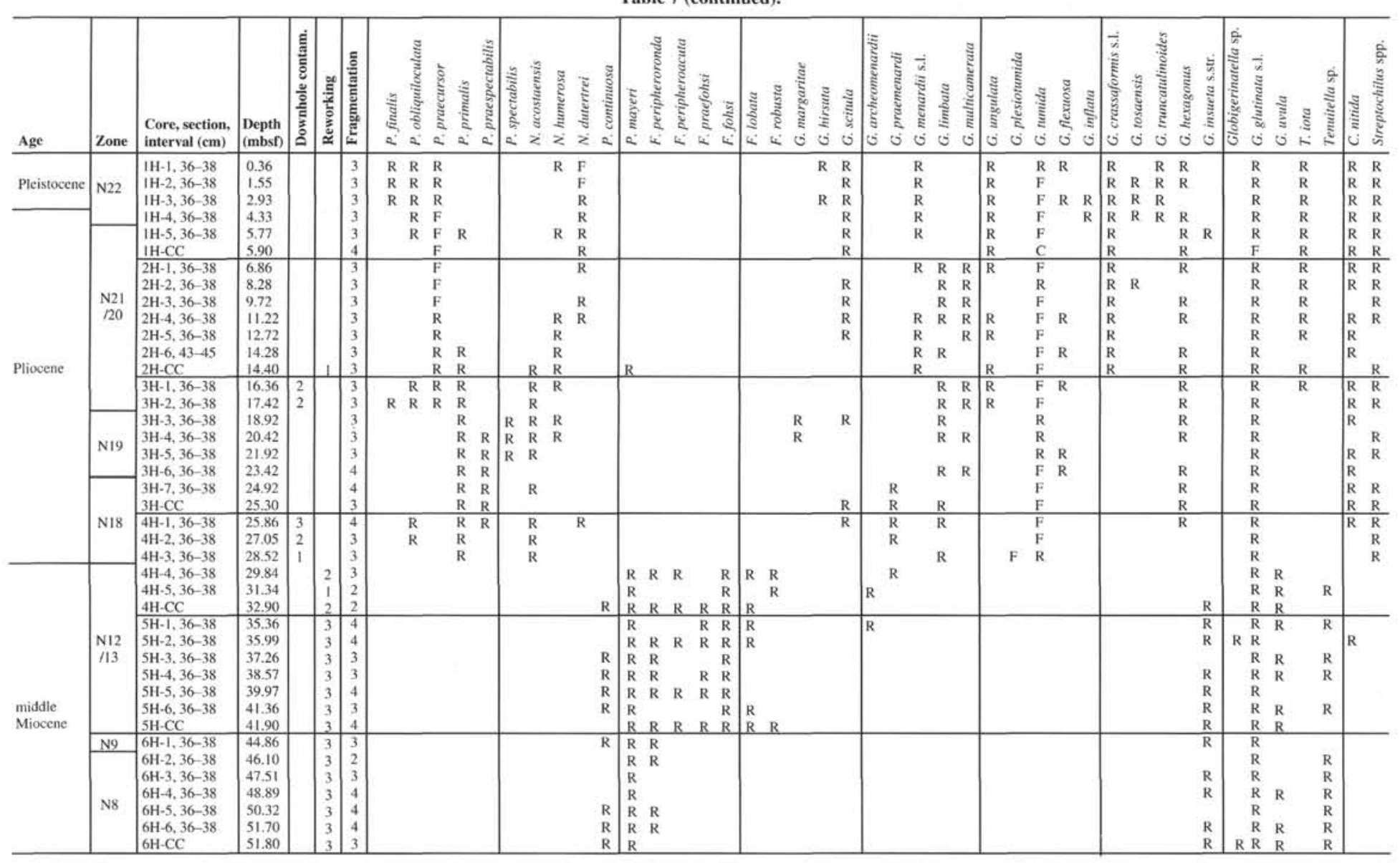


Table 8. Planktonic foraminifer datums in Hole 873B and their stratigraphic positions.

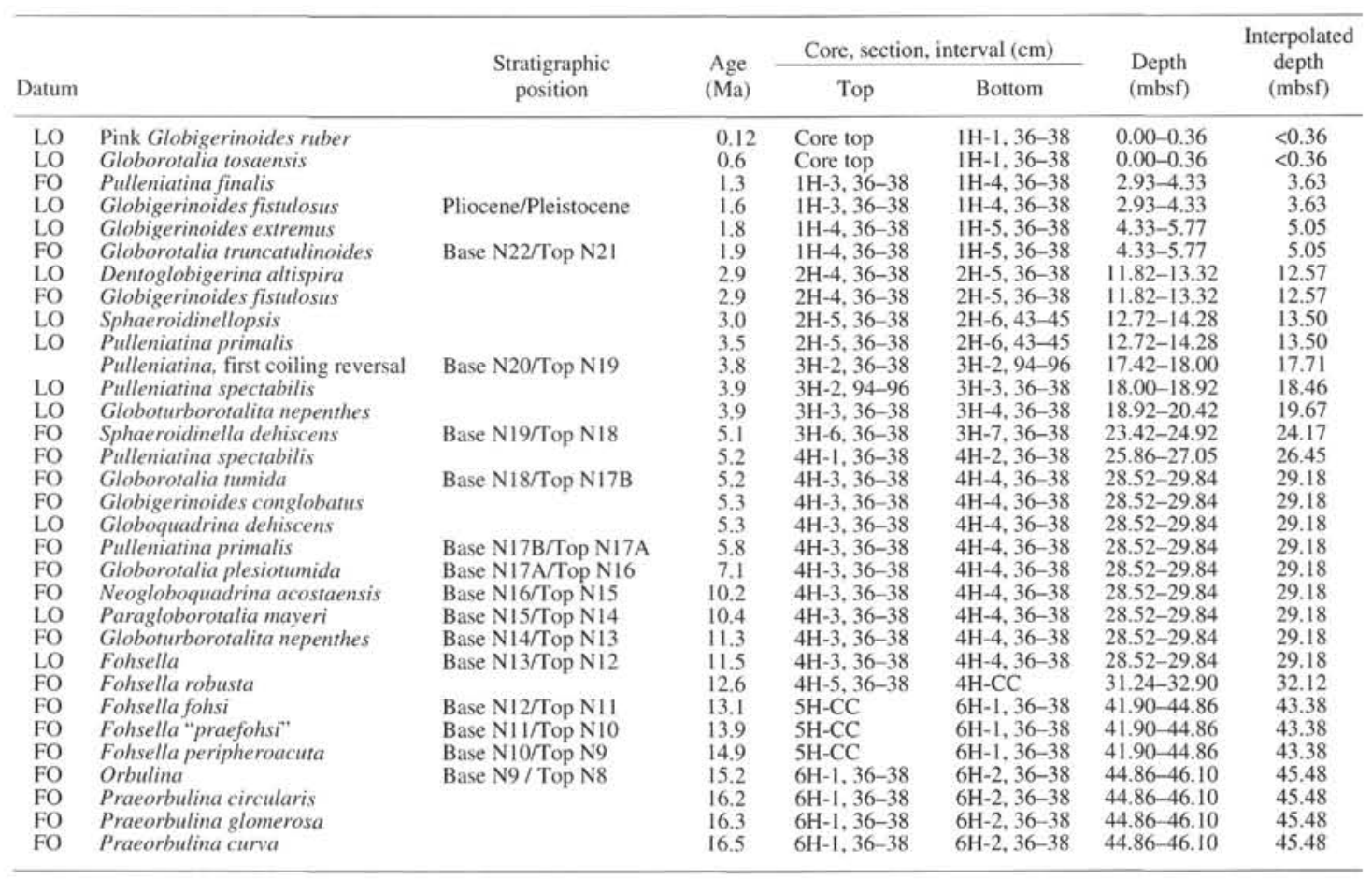

Note: $\mathrm{FO}=$ first occurrence and $\mathrm{LO}=$ last occurrence.

Table 9. Coiling measurements on the Pulleniatina lineage, Hole 873B.

\begin{tabular}{|c|c|c|c|c|}
\hline $\begin{array}{l}\text { Core, section, } \\
\text { interval }(\mathrm{cm})\end{array}$ & $\begin{array}{l}\text { Depth } \\
\text { (mbsf) }\end{array}$ & Ratio & $\begin{array}{c}\text { Dextral } \\
(\%)\end{array}$ & $\begin{array}{c}\text { Principal } \\
\text { morphospecies }\end{array}$ \\
\hline \multicolumn{5}{|l|}{ 144-873B- } \\
\hline $1 \mathrm{H}-1,36-38$ & 0.36 & $50: 0$ & 100 & P. obliquiloculata \\
\hline $\mathrm{IH}-\mathrm{I}, 96-98$ & 0.96 & $50: 0$ & 100 & P. obliquiloculata \\
\hline IH-2, 36-38 & 1.55 & $35: 15$ & 70 & P. obliquiloculata \\
\hline IH $-3,36-38$ & 2.93 & $31: 19$ & 62 & P. obliquiloculata \\
\hline $1 \mathrm{H}-4,36-38$ & 4.33 & $28: 22$ & 56 & P. praecursor \\
\hline $1 \mathrm{H}-5,36-38$ & 5.77 & $40: 10$ & 80 & P. praecursor \\
\hline IH-CC & 5.90 & $32: 18$ & 64 & P. praecursor \\
\hline $2 \mathrm{H}-1,36-38$ & 6.86 & $31: 19$ & 62 & P. praecursor \\
\hline $2 \mathrm{H}-2,36-38$ & 8.28 & $28: 22$ & 56 & P. praecursor \\
\hline $2 \mathrm{H}-3,36-38$ & 9.72 & $28: 22$ & 56 & P. praecursor \\
\hline $2 \mathrm{H}-4,36-38$ & 11.22 & $50: 0$ & 100 & P. praecursor \\
\hline $2 \mathrm{H}-5,36-38$ & 12.72 & $50: 0$ & 100 & P. praecursor \\
\hline $2 \mathrm{H}-6.43-45$ & 14.28 & $50: 0$ & 100 & P. praecursor \\
\hline $2 \mathrm{H}-\mathrm{CC}$ & 14.40 & $50: 0$ & 100 & P. praecursor \\
\hline $3 \mathrm{H}-1,36-38$ & 16.94 & $49: 1$ & 98 & P. primalis \\
\hline $3 \mathrm{H}-2,36-38$ & 17.42 & $31: 19$ & 62 & $P$. primalis \\
\hline $3 \mathrm{H}-3,36-38$ & 18.92 & $3: 47$ & 6 & P. primalis \\
\hline $3 \mathrm{H}-3,36-38$ & 18.92 & $2: 48$ & 4 & P. spectabilis \\
\hline $3 \mathrm{H}-4,36-38$ & 20.42 & $0: 50$ & 0 & $P$. primalis \\
\hline $3 \mathrm{H}-4,36-38$ & 20.42 & $0: 50$ & 0 & P. spectabilis \\
\hline $3 \mathrm{H}-5,36-38$ & 21.92 & $1: 49$ & 2 & $P$ primalis \\
\hline $3 \mathrm{H}-5,36-38$ & 21.92 & $1: 49$ & 2 & P. praespectabilis \\
\hline $3 \mathrm{H}-6,36-38$ & 23.42 & $1: 49$ & 2 & P. praespectabilis \\
\hline $3 \mathrm{H}-7,36-38$ & 24.92 & $1: 49$ & 2 & P. praespectabilis \\
\hline $3 \mathrm{H}-\mathrm{CC}$ & 25.30 & $0: 50$ & 0 & P. praespectabilis \\
\hline $4 \mathrm{H}-1.36-38$ & 25.86 & $4: 46$ & 8 & P. primalis \\
\hline
\end{tabular}

encrusted hardgrounds, as were found at each site (Premoli Silva, Haggerty, Rack, et al., 1993). However, it is inevitable that small pockets of pelagic sediment were able to survive in topographic hollows on the guyot surface. Direct evidence for this is furnished by the record at Lo-En Guyot (Site 872). At this site, material significantly older than that found at the base of the pelagic cap is reworked at higher levels. For example, frequent middle Eocene elements are found mixed into the uppermost Oligocene sequence. Most striking is a single well-preserved Cretaceous planktonic foraminifer (which cannot be a laboratory contaminant) found in sediments at the top of the middle Miocene, at a stratigraphic level about $100 \mathrm{~m}$ above the base of the pelagic cap.

When the pelagic caps began to grow (Fig. 10B), much mixing of sediment occurred. This feature was observed at all three sites. At Limalok (Site 871), the relative ages of the basal sediments are difficult to judge because the base of the pelagic cap is in a biostratigraphically difficult time interval. However, it appears that the mixing was of sediment formed over several million years and occurred, with diminishing severity, for approximately $40 \mathrm{~m}$ above the base. A similar situation was observed at Lo-En Guyot (Site 872), where tests from different levels in the upper Oligocene are mixed together with Eocene tests in the lowest $20 \mathrm{~m}$ of section. An apparent "age inversion" exists near the bottom of that pelagic cap. At Wodejebato Guyot, the severely mixed interval also occupies the bottom 20 $\mathrm{m}$ of the pelagic sequence and involves planktonic foraminifers that must have been originally sedimented over an interval of about 3 m.y.

Severe reworking must have resulted from bottom currents that were too weak to remove all the pelagic material from exposed surfaces but strong enough to cause major sediment redistribution and mixing. These currents were presumably also responsible for winnowing of the fine fraction and severe fragmentation of tests. An analogous environment was described by Lonsdale et al. (1972) at a depth of approximately $2 \mathrm{~km}$ on Horizon Guyot, to the east of the Marshall Islands group at the western end of the Mid-Pacific Mountains. Lonsdale et al. (1972) found a pelagic cap of winnowed foraminiferal sand that had been modified into a series of regular trains of ripples and dunes. Individual dunes ranged up to $1 \mathrm{~m}$ in height and $30 \mathrm{~m}$ in length (see also Lonsdale, 1977, and Lonsdale and Malfait, 1974). Such dune fields could explain cases of apparent age inversion in the lowest part of the record at Site 872. Lonsdale et al. (1972) also recorded a net movement of foraminiferal sand in an upslope direction on Horizon Guyot. This must have occurred at all three Marshall Islands sites because reworked material that must have been derived from pelagic sediment near the perimeter of the guyots was found in the center of the pelagic cap. Further evidence of accelerated bottom currents above seamounts was described by Genin et al. (1986). 
The third phase of pelagic cap formation (Fig. 10C) is when less disturbed sequences accumulate. The distinction between the second and third phases is one of degree, and the transitions at all sites were gradual. During the third phase, mature pelagic caps developed, and the export of sediment from the guyot surfaces was reduced. Although vertical accumulation rates were not much greater than in the second phase, the pelagic caps tended to grow both upward and outward to the fringes of the edifices. When this occurred, reworking of much older material from the guyot edges became less common.

The best examples of mature pelagic caps are Limalok (Site 871) and Lo-En (Site 872) guyots, although the highest portion of Wodejebato Guyot (Site 873) is also similar. In the uppermost portions of all three pelagic caps, the deposition of nannofossil-foraminifer ooze above foraminifer ooze indicates a reduction of winnowing intensity. The degree of test fragmentation is still high, however, and some reworking is observed. Hiatuses still occur at all sites in the higher levels of the pelagic caps.

\section{Backtracking Subsidence}

It is interesting to investigate the water depths at which the Marshall Islands guyots began to develop their pelagic caps. The subsidence history of each guyot can be backtracked to provide an estimate. However, several major areas of uncertainty must affect these estimates. In this exercise, the simplest possible assumptions have been made. The two main areas of uncertainty are outlined below.

1. The subsidence history for each guyot is poorly constrained between platform drowning and the present depth. Not only is there disagreement regarding the correct subsidence curve for old oceanic crust (Parsons and Sclater, 1977; Stein and Stein, 1992), but there is also good reason to think that Marshall Islands guyots have not followed a simple subsidence path. As discussed by Larson et al. (this volume), it appears that the Marshall Islands region has subsided much more slowly than the rate predicted by theoretical ridge-crest subsidence models. The relatively thin platform carbonates on $\mathrm{Li}$ malok (Site 871) and Wodejebato (Sites 874 through 877) guyots strongly support this assertion for the early stages of subsidence and therefore are used in the backtracking exercise to provide an additional constraint on subsidence rates. Initial retardation of subsidence may have been caused by lithospheric heating owing to mid-plate volcanism and/or dynamic support by upwelling of mantle material below the lithosphere (Larson et al., this volume). Because of these uncertainties, a simple linear subsidence curve is assumed for all sites and is regarded as a reasonable approximation. However, if there has been an appreciable reduction of subsidence rate in the region since the Eocene, then the linear approximation will lead to an underestimate of the depths of pelagic cap formation.

2. Eustatic sea-level changes have not been taken into account. The water depth at the time of platform drowning has, in each case, been assumed to be that of the present-day sea level. This may be unjustified because the platforms of Limalok and Wodejebato guyots may have been appreciably below sea level at the time they finally drowned. More importantly, sea level in the Late Cretaceous and middle Eocene was significantly higher (perhaps by $200 \mathrm{~m}$ ) than the modern level (Haq et al., 1987). This assumption would lead to an overestimate of the interpolated water depth for pelagic cap formation. If sea level was higher than the present level at the time of pelagic cap formation, then the depth estimate will be correspondingly low.

Subsidence plots for Limalok (Site 871), Lo-En (Site 872), and Wodejebato (Site 873) guyots are shown in Figures 11, 12, and 13, respectively. These show that the pelagic caps of Limalok and Lo-En guyots have a similar history, despite the fact that drowning occurred earlier at Lo-En Guyot and subsidence was slower. At Limalok Guyot, the estimated depth of pelagic cap initiation is $700 \mathrm{~m}$ and at Lo-En it is $750 \mathrm{~m}$. The caps have grown to similar dimensions by the Holocene, although the details of their histories differ, and both appear to
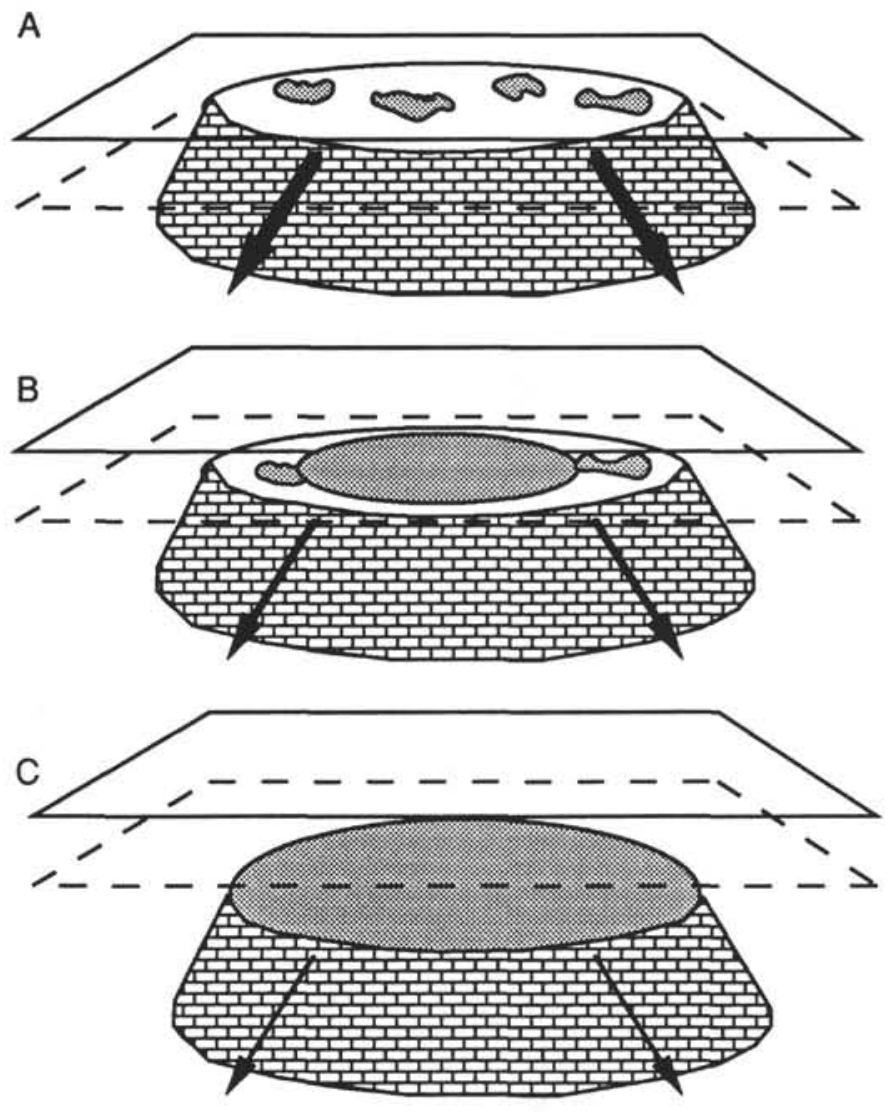

Figure 10. Sketch showing a simple model for pelagic cap accumulation. In Figure 10A, pelagic sediment (shaded) is exported from the guyot surface by storms and currents (arrows). Only isolated patches of sediment accumulate in topographic lows on the guyot surface. In Figure 10B, subsidence takes the guyot to a sufficiently deep level (dashed lines) below the sea surface (full lines) that a pelagic cap begins to grow. Much sediment is still exported from the guyot. In Figure 10C, with further subsidence a fully developed pelagic cap forms and sediment export is further reduced. See text for discussion.

have the potential for further growth. At Wodejebato Guyot (Site $873)$, the estimated depth of pelagic cap initiation is deeper $(>1 \mathrm{~km})$ and the sediment has accumulated at a slower rate. Fragmentation is, in general, more pervasive at Wodejebato Guyot. The reasons for these differences are not entirely clear, as Wodejebato Guyot has comparable dimensions to Limalok and Lo-En guyots. It may be that hydrodynamic conditions at Wodejebato Guyot are less favorable, reflecting the influence of the neighboring edifice (Pikkini Atoll) on local currents.

\section{SUMMARY AND CONCLUSIONS}

Despite their different development histories, the three Marshall Islands pelagic caps are geologically similar structures. The distinctive sedimentological features of the pelagic caps result from the relatively high-energy conditions that are typical of a seamount surface. In each case, there is little dissolution and recrystallization of foraminiferal tests, but severe fragmentation is common. Frequent evidence of reworking exists at each site, particularly toward the bases of the pelagic sequences, although details of the timing and extent of disturbance differ.

After platform drowning in the middle Eocene, the permanent pelagic cap on Limalok Guyot began to develop in the earliest Miocene (Zone N4), at an estimated water depth of $700 \mathrm{~m}$. Growth was interrupted by a hiatus in the early middle Miocene (causing the absence of Zones N10 and N11), followed by a major hiatus spanning 


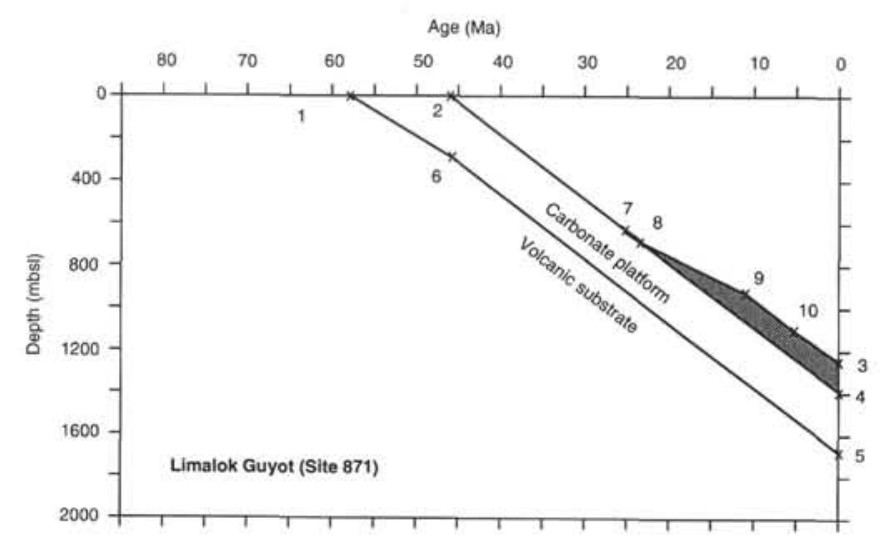

Figure 11. Backtracking of subsidence at Limalok Guyot (Site 871). The growth of the pelagic cap is shown in the shaded field. The estimated depth of pelagic cap initiation is $700 \mathrm{~m}$. The following age/depth estimates were used to construct the curve: (1) age of earliest sediments (late Paleocene), $58 \mathrm{Ma}, 0 \mathrm{~m}$; (2) age of last platform carbonates (middle Eocene), $46 \mathrm{Ma}, 0 \mathrm{~m}$; (3) present depth to pelagic cap, $0 \mathrm{Ma}, 1254 \mathrm{~m}$; (4) present depth to surface of carbonate platform, $0 \mathrm{Ma}, 1388 \mathrm{~m}$; (5) present depth to volcanic substrate, $0 \mathrm{Ma}, 1677 \mathrm{~m}$; (6) depth of volcanic substrate at time of platform drowning, assuming no compaction, 46 Ma, $289 \mathrm{~m} ;$ (7) age of oldest component of pelagic sediment at base of pelagic cap, $25 \mathrm{Ma}, 633 \mathrm{~m}$; (8) age of youngest component at base of pelagic cap, 23 $\mathrm{Ma}, 694 \mathrm{~m}$; (9) age of pelagic cap at bottom of major hiatus, $11 \mathrm{Ma}, 930 \mathrm{~m}$; and (10) age of pelagic cap at top of major hiatus, $5.5 \mathrm{Ma}, 1222 \mathrm{~m}$.

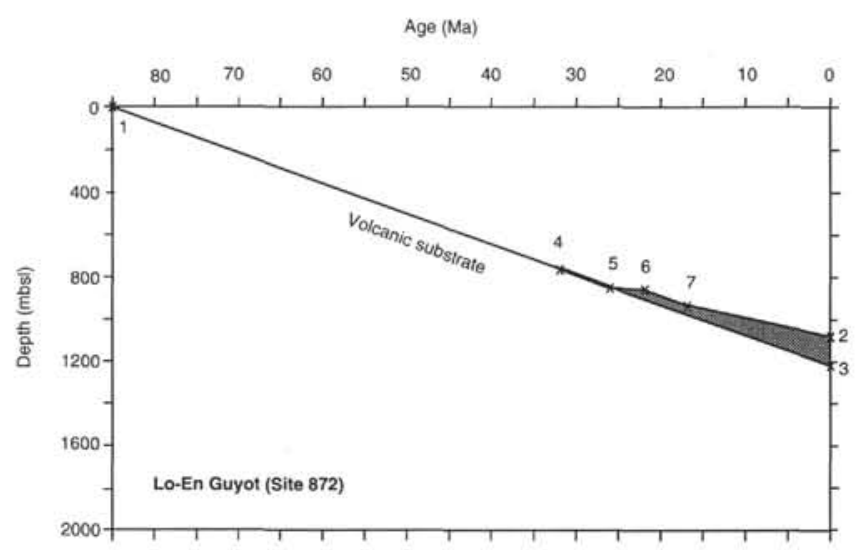

Figure 12. Backtracking of subsidence at Lo-En Guyot (Site 872). The growth of the pelagic cap is shown in the shaded field. The estimated depth of pelagic cap initiation is $700-800 \mathrm{~m}$. The following age/depth estimates were used to construct the curve: (1) age of latest volcanic material, $85 \mathrm{Ma}, 0 \mathrm{~m}$; (2) present depth to pelagic cap, $0 \mathrm{Ma}, 1084 \mathrm{~m}$; (3) present depth to volcanic substrate, 0 $\mathrm{Ma}, 1219 \mathrm{~m}$; (4) age of oldest component of pelagic sediment at base of pelagic cap (Zone P20), $32 \mathrm{Ma}, 760 \mathrm{~m}$; (5) age of youngest component at base of pelagic cap, $26 \mathrm{Ma}, 846 \mathrm{~m}$; (6) age of pelagic cap at bottom of major hiatus, $22 \mathrm{Ma}, 863$ $\mathrm{m}$; and (7) age of pelagic cap at top of major hiatus, $17 \mathrm{Ma}, 935 \mathrm{~m}$.

much of the middle and late Miocene (Zones N13 through N16 are absent). Sedimentation, when it resumed, was slow and episodic until the latest Pliocene. The Pleistocene (Zone N22) is thick and apparently complete.

At Lo-En Guyot, subsidence of the edifice was apparently slower than at Limalok Guyot. The permanent pelagic cap was initiated in the late Oligocene (Zone P22) at an estimated depth of approximately $750 \mathrm{~m}$. Sedimentation was more continuous than at Limalok Guyot. However, three short hiatuses occurred, the first in the early middle Miocene (Zone N9 is missing), the second in the late middle Miocene

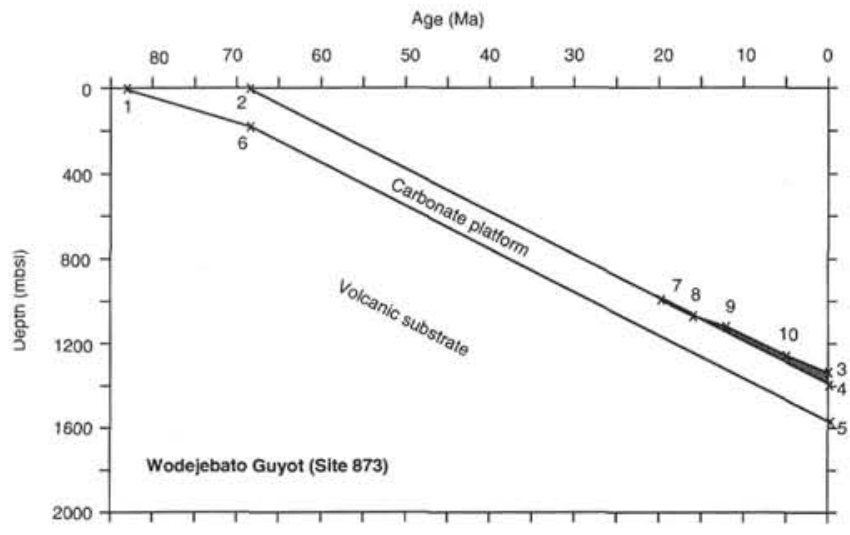

Figure 13. Backtracking of subsidence at Wodejebato Guyot (Site 873). The growth of the pelagic cap is shown in the shaded field. The estimated depth of pelagic cap initiation is $1000-1100 \mathrm{~m}$. The following age/depth estimates were used to construct the curve: (1) age of last volcanics, $83 \mathrm{Ma}, 0 \mathrm{~m}$; (2) age of last platform carbonates (Maastrichtian, G. gansseri Zone), $68 \mathrm{Ma}, 0 \mathrm{~m}$; (3) present depth to pelagic cap, $0 \mathrm{Ma}, 1334 \mathrm{~m}$; (4) present depth to surface of carbonate platform, $0 \mathrm{Ma}, 1388 \mathrm{~m}$; (5) present depth to volcanic substrate (minimum estimate), $0 \mathrm{Ma}, 1569 \mathrm{~m}$; (6) depth of basement at time of platform drowning, assuming no compaction, $68 \mathrm{Ma}, 181 \mathrm{~m}$; (7) age of oldest component of pelagic sediment at base of pelagic cap, and interpolated depth (Zone N5), $20 \mathrm{Ma}, 1031 \mathrm{~m}$; (8) age of youngest component at base of pelagic cap, 16 Ma, $1070 \mathrm{~m}$; (9) age of pelagic cap at bottom of major hiatus, $12 \mathrm{Ma}, 1122 \mathrm{~m}$; and (10) age of pelagic cap at top of major hiatus, $5 \mathrm{Ma}, 1261 \mathrm{~m}$.

(Zone N14 is missing), and the third in the late Miocene to early Pliocene (accounting for the absence of Zone N18).

The pelagic cap on Wodejebato Guyot is considerably thinner than those on Limalok and Lo-En guyots. It initiated at an estimated depth of between 1000 and $1100 \mathrm{~m}$ in the early middle Miocene (Zone N8). A hiatus occurred, as at Limalok Guyot, in the middle Miocene, causing the absence of Zones N10 and N11. Also similar to Limalok Guyot, a second major hiatus occurred, spanning much of the middle to late Miocene (in this case, Zones N13 through N17 are missing). Unlike the other guyots, the upper Pleistocene is missing at Wodejebato Guyot.

There is no clear spatial or temporal pattern to sedimentation in the area. Each guyot displays a unique sedimentary history. The best comparison can be made between the upper portion of the Limalok pelagic cap and the entire sequence on Wodejebato Guyot, but the similarities may be coincidental. The geographically closest pair are Lo-En and Wodejebato guyots (see Fig. 1), which have little in common. Patterns of deposition of pelagic carbonate and hiatuses in the Marshall Island region are evidently very complex. Subsidence of the guyots was certainly an important controlling factor. Local hydrographic effects must also have been important, and these apparently dominate any long-term paleoceanographic changes that may have influenced sedimentation.

\section{SYSTEMATIC TAXONOMY}

The taxonomic approach employed here is, for the sake of biostratigraphic utility and the communication of morphological information, to regard all fossil species merely as useful morphological units (Fordham, 1986; Pearson, 1992, 1993). Thus, expediency has been the main concern in the following taxonomic treatment. Morphospecies have been split where it is justified by the biostratigraphic resolution afforded and have been lumped together in other cases. The subspecies and subgenus taxonomic categories, which are designed to allow greater refinement in natural classifications, are regarded as superfluous. No cladogenesis (lineage branching) or lineage termination (true extinction) is implied on the range charts; consequently, 
they are not regarded as suitable for evolutionary studies, such as for examining diversity trends, for determining speciation or extinction rates, or for studying survivorship.

The taxonomy is based on the compilations of Blow (1969), Kennett and Srinivasan (1983), and Bolli and Saunders (1985). The full references for type descriptions of all the taxa can be found in these standard taxonomic works.

\section{Candeina nitida d'Orbigny}

(Pl. 5, Fig. 17)

Candeina nitida d'Orbigny, 1839, p. 107, pl. 2, figs. 27-28

Discussion. Candeina nitida occurs sporadically in Sites 871,872 , and 873. The earliest occurrence in this material is in the basal Pliocene (Zone N18) of Site 871.

\section{Cassigerinella chipolensis (Cushman and Ponton)}

Cassidulina chipolensis Cushman and Ponton, 1932, p. 98, pl. 15, figs. 2a-c

Discussion. Cassigerinella chipolensis is a frequent component of the fine fraction $(<150 \mu \mathrm{m})$ of middle Miocene and older sediments at Site 871, but it is less common at Sites 872 and 873 . Large specimens $(>150 \mu \mathrm{m})$ occur sporadically in the upper Oligocene of Site 872; however, in this case, they are of little use biostratigraphically because of the severe reworking throughout that interval.

$$
\text { Catapsydrax dissimilis (Cushman and Bermudez) }
$$$$
\text { (Pl. 1, Fig. 18) }
$$

Globigerina dissimilis Cushman and Bermudez, p. 25, pl. 3, figs. 4-6

Discussion. Catapsydrax dissimilis is distinguished from $C$. unicavus by the presence of more than one infralaminal aperture around the bulla. It is rare throughout its range at Sites 871,872, and 873 and subordinate to $C$. unicavus. The rarity of Catpsydrax spp. is a characteristic of the western Pacific (Kennett et al., 1985). The wall is cancellate. No spine holes were observed.

\section{Catapsydrax unicavus Bolli, Loeblich and Tappan}

Catapsydrax unicavus Bolli, Loeblich and Tappan, p. 37, pl. 7, figs. 9a-c

Discussion. See comments under $C$. dissimilis.

$$
\text { Chiloguembelina cubensis (Palmer) }
$$

$$
\text { (PI. 1, Fig. 3) }
$$

Gümbelina cubensis, Palmer, 1934, p. 74, text-figs. 1-6

Discussion. At Site 872, frequent reworked specimens of Chiloguembelina cubensis are present in the $<150-\mu \mathrm{m}$ size fraction of Cores $144-872 \mathrm{C}-16 \mathrm{H}$ and $-17 \mathrm{H}$. Most specimens show well-developed longitudinal striae.

\section{Clavatorella bermudezi (Bolli)}

$$
\text { (PI. 5, Figs. 11, 12, and 21) }
$$

Hastigerinella bermudezi Bolli, 1957, p. 112, pl. 25, figs. 1a-c

Discussion. Sporadic specimens of Clavatorella bermudezi were found in a restricted range in the lower to middle Miocene of Site 871 and, more commonly, at Site 872 . No spine holes were detected. Like other clavate species, there is a great range in the degree of radial elongation of the chambers and the style of chamber addition. A few specimens were found that do not show the extreme radial elongation of the chambers characteristic of that taxon and which appear to be transitional to Globorotaloides hexagonus. SEM investigation shows that some forms apparently constructed an umbilical plate by fusion of the apertural flanges of succeeding chambers (see Pl. 5, Fig. 21).

Clavatorella nicobarensis Srinivasan and Kennett

Clavatorella nicobarensis Srinivasan and Kennett, p. 78, pl. 1, figs. 1-13

Discussion. A few specimens of Clavatorella nicobarensis were found in Sample 144-873B-2H-CC.

\section{Dentoglobigerina}

Discussion. The genus Dentoglobigerina originated in the Eocene and flourished in the Oligocene to early Miocene interval. The morphospecies observed form a difficult plexus of intergrading forms. See discussion under Globoquadrina.
"Dentoglobigerina" altispira (Cushman and Jarvis)

(Pl. 4, Figs. 20 and 23)

Globigerina altispira Cushman and Jarvis, 1936, p. 5, pl. 1, figs. 13a-c

Discussion. "Dentoglobigerina" altispira is a tropical form and is abundant in Leg 144 material. In this study, the form "Dentoglobigerina" globosa Bolli is included within the morphologic range of " $D$." altispira. In the lower part of its range at Site 872, "Dentoglobigerina" altispira was found to apparently intergrade with $D$. globularis, which in turn intergrades with $D$. galavisi. Similar observations have led other authors to include altispira in the genus Dentoglobigerina (typified by galavisi), which is probably spinose on account of its supposed descent from the spinose genus Subbotina. However, at the intervals where apparent intergradation among the dentoglobigerinids was observed, the preservation is not sufficient to study the wall ultrastructure closely. At higher levels (e.g., the middle Miocene), typical altispira was found to have a wall much like Globoquadrina dehiscens, and no trace of spine holes was found (see Pl. 4, Fig. 23). Hence, the assignment to the genus Dentoglobigerina is provisional.

\section{Dentoglobigerina baroemoenensis (LeRoy)}

Globigerina baroemoenensis LeRoy, 1939, p. 263, pl. 6, figs. 1-2; pl. 27, figs. 4 and 8

Discussion. Dentoglobigerina baroemoenensis is similar to D. galavisi but possesses subangular chambers that lean out from the umbilicus. It is a long-ranging form that last occurred in the late Miocene.

Dentoglobigerina globularis (Bermudez)

Globoquadrina globularis Bermudez, 1961, p. 311, pl. 13, figs. 4-6

Discussion. Dentoglobigerina globularis is a central form in the upper Oligocene dentoglobigerinid plexus. It is distinguished from " $D$." altispira s.l., of which it may be the ancestral form (but see comments under " $D$." altispira above), by its lower trochospiral and more globular chambers. Typical forms possess 4 to $4 \frac{1}{2}$ chambers in the final whorl, compared to 5 , which is typical of the "D." altispira group. D. globularis is also close to D. baroemoenensis, which has 4 subangular chambers in the final whorl, and $D$. galavisi, which has 3 to $3 \frac{1}{2}$ chambers in the final whorl, a tighter coil, and a narrower umbilicus. Intermediate specimens between these various forms are common.

\section{Dentoglobigerina larmeui Akers}

Globoquadrina larmeui Akers, 1955, p. 661, pl. 65, figs. 4a-c

Discussion. Dentoglobigerina larmeui is an inflated compact dentoglobigerinid with $3 \frac{1}{2}$ to 4 chambers in the final whorl. The spire height is variable.

\section{Fohsella}

Discussion. The phylogeny of the "Globorotalia fohsi" lineage is sufficiently well known, and its morphology sufficiently distinct, to justify its inclusion in a separate genus from Globorotalia. Other subgenera of Globorotalia may ultimately prove to be valid genera but are at present too poorly understood for confident usage. Several morphospecies can be recognized and appear to form a single chronocline from the rounded $F$. peripheroronda morphospecies to the angular keeled form $F$, fohsi and its variants. The lineage is of great utility in middle Miocene biostratigraphy.

\section{Fohsella fohsi (Cushman and Ellisor)} (PI. 4, Fig. 11)

Globorotalia fohsi Cushman and Ellisor, 1939, p. 12, pl. 2, figs. 6a-c

Discussion. Fohsella fohsi is a keeled form that fully intergrades with $F$. "praefohsi," F. lobata, and F. robusta. Although many authors describe $F$. fohsi as possessing a complete keel, the feature is always best expressed on the final chamber (see, e.g., Kennett and Srinivasan, 1983). Earlier chambers are tumid and usually possess an imperforate band rather than a well-developed keel.

\section{Fohsella lobata (Bermudez)}

$$
\text { (Pl. 4, Fig. 12) }
$$

Globorotalia lobata Bermudez, 1949, p. 286, pl. 22, figs. 15-17

Discussion. Fohsella lobata is distinguished from $F$. fohsi by possessing a strongly lobate periphery and a better developed keel; intermediates are common. The first appearance of this form postdates the first appearance of 
F. fohsi. However, scattered lobate specimens occur in populations in the peripheroronda and "praefohsi" stage of development (see also Chaisson and Leckie, 1993), but these were excluded from $F$. lobata because of the lack of an imperforate band on the periphery.

\section{Fohsella peripheroacuta (Blow and Banner)}

(Pl. 4, Fig. 10)

Globorotalia (Turborotalia) peripheroacuta Blow and Banner, 1966, p. 294, pl. 1, figs. 2a-c

Discussion. Fohsella peripheroacuta has a pinched, subacute periphery but no incipient keel development. The concept of Kennett and Srinivasan (1983) is followed in distinguishing this form from $F$. "praefohsi," with which it intergrades.

\section{Fohsella peripheroronda s.str. (Blow and Banner)} (Pl. 4, Figs. 6-9)

Globorotalia (Turborotalia) peripheroronda Blow and Banner, 1966, p. 294, pl. 1, figs. la-c

Discussion. Fohsella peripheroronda is the earliest representative of the Fohsella lineage and intergrades with the other forms stratigraphically through $F$. peripheroacuta. The $\mathrm{FO}$ of $F$. peripheroronda s.str. in this material is in Zone N7. However, closely similar forms intergrading with Paragloborotalia kugleri populations are present in Subzone $\mathrm{N} 4 \mathrm{~b}$, but they are thought to belong to $P$. kugleri (see discussion under Paragloborotalia). Some authors have noted that an apparent intergradation occurred between $P$. kugleri and $F$. peripheroronda in the earliest Miocene (e.g., Keller, 1981; Kennett and Srinivasan, 1983). The stratigraphic gap that exists between the earlier and later forms was interpreted by Keller (1981) to be the result of dissolution. Here it is suspected that the gap is real and that six-chambered $P$. kugleri is a phylogenetically distinct homeomorph of $F$. peripheroronda.

\section{Fohsella "praefohsi" Blow and Banner}

?Globorotalia (Globorotalia) praefohsi Blow and Banner, 1966, p. 295, pl. 1, figs. 3-4; pl. 2, figs. 6-7 and 10-11

Globorotalia (Fohsella) praefohsi Blow and Banner, Kennett and Srinivasan, 1983, p. 98 , pl. 22 , figs. $7-9$

Discussion. The concept of Blow and Banner (1966), Kennett and Srinivasan (1983), and others is followed in regarding $F$. "praefohsi" as an incipiently carinate form directly preceding $F$. fohsi in the evolutionary sequence of the Fohsella lineage. Note, however, the comments of Bolli and Saunders (1985, p. 213) on the holotype of this taxon.

\section{Fohsella robusta (Bolli)}

Globorotalia fohsi robusta Bolli, 1950, pp. 84 and 89, pl. 15, figs. 3a-c

Discussion. Fohsella robusta is distinguished from $F$. fohsi and $F$. lobata by its circular periphery. Forms transitional to both $F$. fohsi and $F$. lobata were observed.

\section{Globigerina s.l.}

Discussion. Globigerina is characterized by a smooth spinose wall bearing raised spine bases that is not cancellate as in Globigerinoides s.str. The wall texture of the "Globigerina" ciperoensis group is cancellate, however, and it may be that "G." ciperoensis and related forms should be included in a new genus.

\section{"Globigerina" angulisuturalis Bolli}

(Pl. 1, Figs. 13 and 14)

Globigerina angulisuturalis Bolli, 1957, p. 109, pl. 22, figs. 11a-c

Discussion. This is a distinctive form with deeply excavated U-shaped intercameral sutures and radially flaring chambers. At Site 872, the taxon is very common in Cores $144-872 \mathrm{C}-15 \mathrm{H}$ through $-17 \mathrm{X}$ and dominates most of the $<150-\mu \mathrm{m}$ size fraction. Intermediate morphologies between this taxon and "Globigerina" ciperoensis occur, although they are not as common as either "G." ciperoensis or " $G$." angulisuturalis. In this work, the intermediates have been included in the nearest of these two taxa, although some authors record such forms under the name " $G$." anguliofficinalis (which, according to Blow [1969], was the ancestral form of " $G$." angulisuturalis in the lower Oligocene).
"Globigerina" ciperoensis Bolli

(Pl. 1, Figs. 11 and 12)

Globigerina ciperoensis Bolli, 1954, p.1, figs. 3-6

Discussion. See comments under "G." angulisuturalis. "G." ciperoensis usually possesses 5 chambers in the final whorl and an umbilical aperture, although forms with $4 \frac{1}{2}$ chambers and an aperture that extends beyond the umbilicus are also common in this material. High-spired variants, often with $4 \frac{1}{2}$ chambers in the final whorl, are included by some authors as " $G$." fariasi. These are not separated here.

\section{Globigerina bulloides s.1.}

\section{Globigerina bulloides d'Orbigny, 1826, p. 277}

Discussion. Globigerina s.str. is scarce in the Miocene to Holocene in Leg 144 material. Consequently, no attempt has been made to separate $G$. falconensis and other related forms. See comments under $G$. praebulloides.

\section{Globigerina ouachitaensis Howe and Wallace}

Globigerina ouachitaensis ouachitaensis Howe and Wallace, 1932, p. 74, pl. 10, figs. 7a-b

Discussion. Globigerina ouachitaensis possesses four slowly increasing globular chambers in the final whorl and a wide umbilicus.

\section{Globigerina praebulloides Blow}

Globigerina praebulloides Blow, 1959, p. 180, pl. 8, figs. 47a-c

Discussion. Globigerina praebulloides is a lobate form with an elongate equatorial profile. The aperture is usually a lower arch than is typical of $G$. bulloides. The wall texture is similar.

\section{"Globigerina" prasaepis Blow}

Globigerina prasaepis, Blow 1969, pl. 10, fig. 13; pl. 18, figs. 3-7

Discussion. The globular chambers and elongate aperture is typical for this taxon. "Dentoglobigerina" venezuelana is similar but larger.

\section{Globigerinatella}

Discussion. Bolli and Saunders (1985) stated that Globigerinatella insueta, which they regard as the only species of Globigerinatella, appears abruptly as a "fully developed form," making it taxonomically straightforward and biostratigraphically useful. According to them, it is distinguished from related forms by a suite of characters, including its globular test and irregularly distributed bullae, which may be individual circular coverings for sutural or areal apertures or may be elongated tubes covering the intercameral sutures. Kennett and Srinivasan (1983) also regard a combination of characters, including the embracing final chamber and the presence of sutural and areal supplementary apertures as diagnostic features.

Although Globigerinatella is relatively rare in these assemblages (as elsewhere), the large sample size and good preservation have permitted a detailed study of the genus. Every intermediate is found between $G$. insueta s.str. and its ancestral form Globigerinita glutinata. The characters described above do not appear simultaneously. As was observed by Chaisson and Leckie (1993) at Site 806 (Ontong Java Plateau), the number of areal apertures (or areal bullae, which commonly cover areal apertures) on the final chamber was seen to decrease with depth. This was studied in detail at Site 871 and holds promise for biostratigraphy in this interval, which is otherwise difficult to subdivide by calcareous plankton (Fig. 14). Forms of Globigerinatella that lack areal apertures are present throughout the range of the genus, but are dominant at lower intervals. The earliest forms (e.g., at Site 871, below Sample $144-871 \mathrm{~A}-11 \mathrm{H}-6,60-62 \mathrm{~cm}$ ) are exclusively of this type.

Cushman and Stainforth's (1945) type material of Globigerinatella insueta at the Smithsonian Institution was examined as part of this study. The holotype and all paratypes were found to possess areal apertures, although this is not apparent on all of the original illustrations. Consequently, a strict concept of $G$. insueta is employed, and areal apertures or bullae are regarded provisionally as diagnostic. Other forms of Globigerinatella have been recorded as Globigerinatella sp.

A specimen attributable to Globigerinatella $\mathrm{sp}$. was illustrated by Chaisson and Leckie from the Ontong-Java Plateau (Chaisson and Leckie, 1993, pl. 10, fig. 3), who also recorded full intergradation between $G$. insueta and Globigerinita glutinata. It may be that the appearance of Globigerinatella (used to 
recognize the base of Zone N6) in the western Pacific does not correlate well to other regions. Further research is needed to clarify these issues.

Globigerinatella insueta Cushman and Stainforth s.str. (Pl. 2, Figs. 13-22)

Globigerinatella insueta Cushman and Stainforth, 1945, p. 69, pl. 13, figs. 6-9

Discussion. Globigerinatella insueta s.str. is distinguished from Globigerinatella sp. by the presence of one or more areal apertures or areal bullae. Considerable variation occurs in the number of areal apertures and the shape and arrangement of bullae. The first $G$. insueta s.str. at Site 871 possess just a single areal aperture (see Fig. 14). Later $G$. insueta s.str. possess many areal apertures, which are typically situated in a well-demarcated area on one side of the final chamber.

\section{Globigerinatella sp.}

(Pl. 2, Figs. 7-12)

Globigerinatella insueta Cushman and Stainforth, Chaisson and Leckie 1993 (partim), p. 157, pl. 10, figs. 3-5

Discussion. In Hole 871A, many intermediates from Globigerinatella to Globigerinita exist at the beginning of the range of Globigerinatella (i.e., the base of Zone N6, as provisionally recognized here). The morphology of these forms is variable and intergrades from Globigerinita glutinata to fully developed Globigerinatella insueta s. str. These early populations lack members with areal apertures or bullae. Such forms are recorded under the name Globigerinatella sp. Globigerinatella sp. is distinguished from Globigerinita glutinata s.l. by having a more spherical morphology and the presence of a second generation of bullae, which are usually around the final chamber/ swollen bulla typical of the species.

\section{Globigerinella}

Discussion. The genus Globigerinella is apparently a continuous chronocline from $G$. obesa in the late Oligocene, through $G$. praesiphonifera in the early and middle Miocene, to G. siphonifera in the late Miocene to Holocene.

\section{Globigerinella siphonifera (Brady)}

(PI. 5, Figs. 14 and 15)

Globigerina siphonifera d'Orbigny, 1839 , fig. $2.3 \mathrm{~g}-\mathrm{h}$

Globigerina aequilaterlis Brady, 1884, p. 9, pl. 80, figs. 18-21

Discussion. Globigerinella siphonifera is similar to G. praesiphonifera, but it is larger and shows a tendency toward planispiral coiling in the adult stage. Juveniles, however, are indistinguishable from $G$. praesiphonifera.

Globigerinella obesa (Bolli)

Globorotalia obesa Bolli, 1957, p. 119, pl. 29, figs. 2a-c

Discussion. Globigerinella obesa occurs in Zone P22 at Site 872. It is distinguished from $G$. praesiphonifera by its more compact test and more inflated chambers and from Globigerina praebulloides by its umbilical/ extraumbilical aperture. It apparently represents an intermediate between Globigerina and Globigerinella.

\section{Globigerinella praesiphonifera (Blow)}

$$
\text { (PI. 5, Fig. 13) }
$$

Hastigerina (Hastigerina) siphonifera praesiphonifera Blow, 1969, p. 408, pl. 54, figs. 7-9

Discussion. Globigerinella praesiphonifera intergrades with G. obesa and G. siphonifera at the beginning and end of its range, respectively. Even in large tests with a loosely attached final chamber, no trend was observed toward planispirality, as seen in G. siphonifera.

\section{Globigerinita}

Discussion. The genus Globigerinita is characterized by a globular test, an umbilical aperture, and a microperforate wall texture. Globigerinita is almost universally present in Leg 144 pelagic sediments and often dominates the $<150-\mu \mathrm{m}$ size fraction. Only two morphospecies were differentiated, but this may be a function of the paucity of characters rather than because of the low biological diversity in the genus.

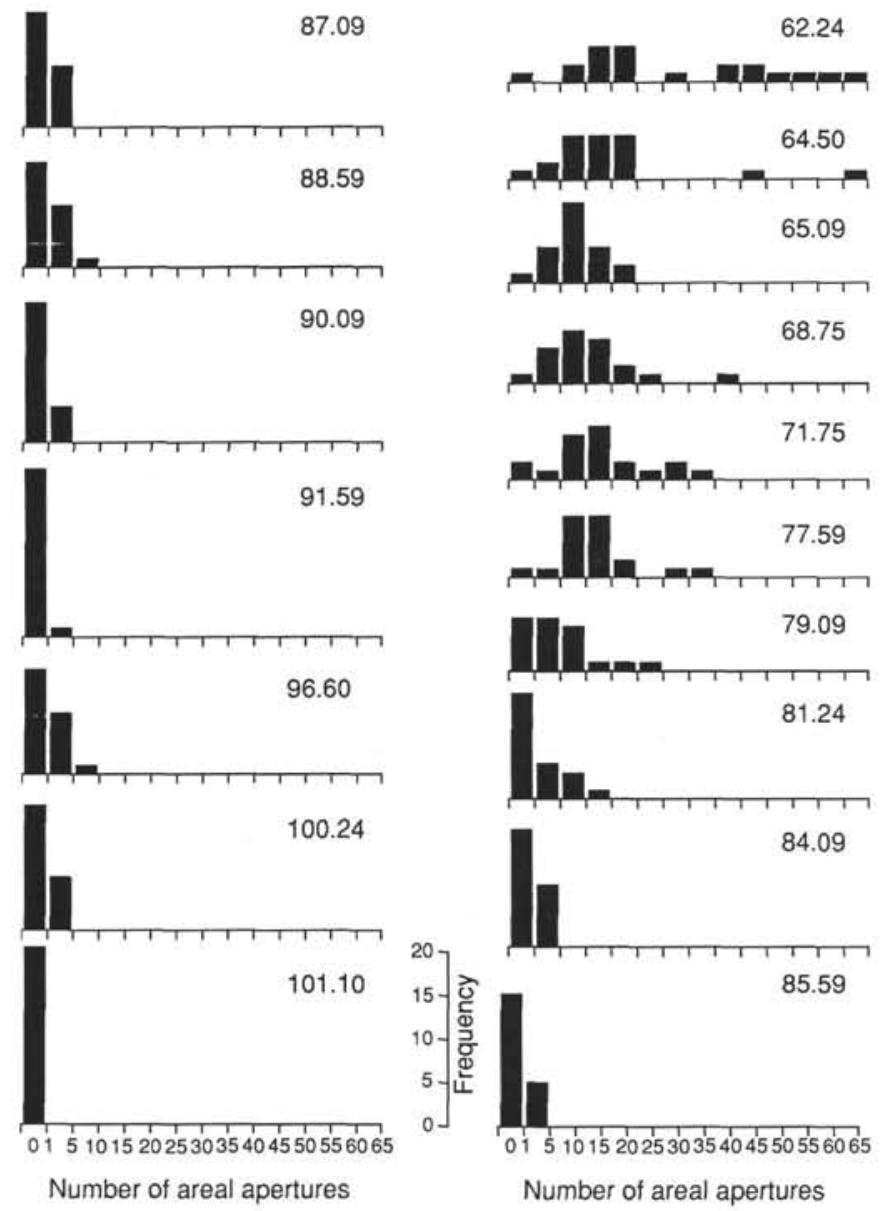

Figure 14. Counts of areal apertures on the final chambers of Globigerinatella spp. in Hole 871A. Apertures on 20 individuals from each sample were counted. Numbers for each sample indicate depth in meters below seafloor. Below 101.10 mbsf, all specimens of Globigerinatella lack areal apertures.

\section{Globigerinita glutinata (Egger)}

(Pl. 2, Figs. 1-6)

Globigerina glutinata Egger, p. 371, pl. 13, figs. 19-21

Discussion. A wide concept is taken to include bullate and nonbullate forms (such as G. juvenilis, G. naparimaensis, and G. ambitacrena). Globigerinita glutinata is found to intergrade with Globigerinatella insueta (see discussion under Globigerinatella).

\section{Globigerinita uvula (Ehrenberg)}

(Pl. 1, Figs. 21 and 22)

Pylodexia uvula Ehrenberg, 1861, p. 308; Ehrenberg, 1873, pl. 2, figs. 24 and 25

Discussion. Intermediates are found between high-spired Globigerinita uvula and low-spired Globigerinita glutinata. The high-spired globigerinitids are present intermittently throughout the Miocene at Sites 871, 872, and 873. The maximum spire height varies from sample to sample. Sporadic specimens with a supplementary spiral aperture were found, but they have not been differentiated. In the Oligocene of Hole 872C, forms of G. uvula with a pointed "sacculiferid" chamber are common (see Pl. 1, Fig. 22).

\section{Globigerinoides}

Discussion. The genus Globigerinoides is characterized by globular chambers, supplementary apertures, and a cancellate spinose wall. "Globigerinoides" primordius was probably derived independently from Globigerina praebulloides (see Leckie et al., 1993). A number of phylogenetic lineages have been recognized by other workers and are discussed below. 
Globigerinoides altiaperturus Bolli

Globigerinoides triloba altiapertura Bolli, 1957, p. 113, pl. 25, figs. 7a-c

Discussion. Globigerinoides altiaperturus is very similar to G. obliquus and differs only in the symmetrical shape of the final chamber. The two taxa fully intergrade. The G. altiaperturus morphotype is restricted to the lower Miocene, where it is frequent at all three sites.

\section{Globigerinoides bisphericus Todd}

(PI. 3, Fig. 2)

Globigerinoides bisphericus Todd, 1954, p. 681, pl. 1, figs. 1a-c

Discussion. Globigerinoides bisphericus is similar to G. trilobus s.1., but it has a larger final chamber and a much reduced umbilicus. It is distinguished from Praeorbulina sicana, with which it intergrades, in that it possesses only three apertures around the final chamber. Included in this taxon are forms with the final chamber much enlarged relative to the rest of the test (see Kennett and Srinivasan, 1983) and forms with the penultimate chamber also enlarged to give the test a bispherical shape, akin to the "Praeorbulina transitoria" morphotype that is not recognized in this study.

\section{Globigerinoides conglobatus (Brady)}

Globigerina conglobata Brady, 1879, p. 28b; Brady, 1884, p. 9, pl. 80, figs. $1-5$

Discussion. Typical forms exist in the Pleistocene. Pliocene forms are usually smaller and less spherical. See comments under $G$. extremus.

\section{Globigerinoides extremus Bolli}

Globigerinoides obliquus extremus Bolli and Bermudez, 1965, p. 139, pl. 1, figs. $10-12$

Discussion. This is the end form of the Globigerinoides obliquus lineage, which has a sharply defined extinction level. Although the form may be ancestral to G. conglobatus (Kennett and Srinivasen, 1983), no intermediates were found in these samples.

\section{Globigerinoides fistulosus (Schubert)}

$$
\text { (Pl. 5, Fig. 7) }
$$

Globigerina fistulosus Schubert, 1910, p. 323, text-fig. 2, figs. 13a-c

Discussion. According to some authors (e.g., Bolli and Saunders, 1985), Globigerinoides fistulosus is restricted to the mid-Pliocene, whereas others recorded its presence only in late Pliocene Zone N21 (e.g., Jenkins and Orr, 1972; Kennett and Srinivasan, 1983). In Sites 871 through 873, Globigerinoides fistulosus occurs mainly in Zone N21 and the lower part of Zone N22 (see also Parker, 1967). Its disappearance is used to approximate the Pliocene/Pleistocene boundary.

\section{Globigerinoides mitra Todd}

(Plate 5, Fig. 5)

Globigerinoides mitra Todd, 1957, p. 302, pl. 78, figs. 3 and 6

Discussion. Globigerinoides mitra is common in Zone N8 at all three sites and appears to range as high as Zone N10. It is a large, high-spired form with high-arched supplementary apertures. In extreme forms, the chambers are radially elongate (almost clavate).

\section{Globigerinoides obliquus Bolli}

\section{Globigerinoides obliqua Bolli, 1957, p. 113, pl. 25, figs. 10a-c}

Discussion. Globigerinoides obliquus generally possesses $3 \frac{1}{2}$ to 4 chambers in the final whorl and an obliquely compressed final chamber. It intergrades fully with the end form of the lineage, Globigerinoides extremus. G. obliquus is a consistent taxon in the Miocene and Pliocene of the Leg 144 sites.

\section{"Globigerinoides" primordius Blow and Banner}

Globigerinoides quadrilobatus primordius Blow and Banner, 1962, p. 115, pl. 9, figs. Dd-Ff

Discussion. "Globigerinoides" primordius is very close to Globigerina praebulloides, from which it differs principally in the possession of a supplementary aperture, which may vary considerably in size. The wall texture is not cancellate, and the relationship with Globigerinoides s.str. is apparently not close. The first appearance of "G." primordius in Hole $872 \mathrm{C}$ is in Sample $144-872 \mathrm{C}-15 \mathrm{H}-\mathrm{CC}$, in which the species is already reasonable abundant. Sporadic occurrences of Globigerinoides s.str. in the lower part of Hole 872C are probably downhole contaminants.

\section{Globigerinoides ruber s.l. (d'Orbigny)}

$$
\text { (Pl. 5, Fig. 4) }
$$

Globigerina rubra d'Orbigny, 1839, p. 82, pl. 4, figs. 12-14

Discussion. A wide concept was taken to include morphotypes such as the high-spired Globigerinoides pyramidalis, which occurs sporadically throughout the range of $G$. ruber. A break in the stratigraphic range was observed at Sites 871 and 873 , but it is obscured by reworking at Site 872 . The older form is included by some authors as Globigerinoides subquadratus. However, the differences between the two homeomorphs are subtle and, considering the extent of downhole contamination and reworking in this material, the two taxa were lumped for the purpose of picking. Pink-pigmented forms are present in the Pleistocene of all three sites.

\section{Globigerinoides sacculifer (Brady)}

Globigerina sacculifer Brady, 1877, p. 164, pl. 9, figs. 7-10; Brady, 1884, p. 604 , pl. 80, figs. 11-17, pl. 81, fig. 2, and pl. 82, fig. 4

Discussion. Although Globigerinoides sacculifer is widely regarded as a variant of Globigerinoides trilobus, it is included as a separate taxon because of the sacculiferid morphology. It has a restricted stratigraphic range in the Leg 144 material and also forms an intermediate to Globigerinoides fistulosus.

\section{Globigerinoides trilobus (Reuss)}

(Pl. 3, Fig. 1, and Pl. 5, Fig. 6)

Globigerina triloba Reuss, p. 374, pl. 447, figs. 11a-c

Discussion. A wide morphological concept has been taken, including such intergrade forms as $G$. quadrilobatus and $G$. immaturus, which are apparently varieties of one living species (Hemleben et al., 1989). Other morphotypes are distinguished, however, because they have biostratigraphic significance (see discussions under $G$. sacculifer and $G$. fistulosus). The first appearance of $G$. trilobus s.l. at Site 872 is in Sample 144-872C-14H-6, 20-22 cm. However, the taxon is infrequent until the top of Core 144-872C-14H.

\section{Globoquadrina}

Discussion. Some confusion exists over distinctions between the genera Globoquadrina (type species G. dehiscens, a Miocene species) and Dentoglobigerina (type species D. galavisi, an Eocene-Oligocene species). According to Kennett and Srinivasan (1983), the two genera are phylogenetically unrelated. They included the altispira group of the Neogene in Dentoglobigerina. Spezzaferri and Premoli Silva (1991) largely followed this scheme but placed baroemoenensis in Dentoglobigerina.

Globoquadrina binaensis (Koch)

(Pl. 1, Fig. 20)

Globigerina binaensis Koch, 1935, p. 746, figs. 22a-c

Discussion. G. binaensis is a distinctive species bearing a cutaway final chamber. See comments under G. sellii.

Globoquadrina dehiscens (Chapman, Parr and Collins)

$$
\text { (Pl. 4, Figs. } 21 \text { and 24) }
$$

Globorotalia dehiscens Chapman, Parr and Collins, 1934, p. 569, pl. 11, figs. $36 a-c$

Discussion. Globoquadrina dehiscens intergrades with its ancestral taxon, G. praedehiscens. G. dehiscens is more angular than G. praedehiscens and possesses four chambers in the final whorl. The first appearance of $G$. dehiscens in Hole 872B is above the diversification level of Globigerinoides spp. and is used to mark the Subzone N4a/N4b boundary.

\section{Globoquadrina praedehiscens Blow and Banner}

Globoquadrina dehiscens praedehiscens Blow and Banner, 1962, p. 116, pl. 15 , figs. Q-S

Discussion. Globoquadrina praedehiscens is similar to $G$. dehiscens; however, it has a rounder test and fewer than four chambers in the final whorl. 


\section{Globoquadrina sellii Borsetti}

$$
\text { (Pl. 1, Fig. 8) }
$$

Globoquadrina sellii Borsetti, 1959, pp. 209-211, pl. 1, figs. 3a-c

Discussion. This taxon fully intergrades with $G$. binaensis, from which it is distinguished by having less well-developed flattening of the apertural face of the last chamber.

$$
\text { Globoquadrina tripartita (Koch) }
$$

(PI. 1, Fig. 9)

Globigerina bulloides var, tripartita Koch, 1926, p. 746, figs. 21a-b

Discussion. Globoquadrina tripartita is distinguished from related species by its possession of three closely appressed chambers in the final whorl, usually with a tangentially flattened final chamber.

\section{"Globoquadrina" venezuelana (Hedberg)}

$$
\text { (Pl. 1, Fig. 10) }
$$

"Globigerina" venezuelana Hedberg, 1937, p. 681, pl. 92, figs. 7a-b

Discussion. "Globoquadrina" venezuelana is a large, compact globular form that ranges throughout the Miocene and shows great variability of form. Its relationship with the dentoglobigerinids and globoquadrinids is uncertain.

$$
\text { "Globoquadrina" sp. }
$$

Discussion. This is a large form distinguished from " $G$." venezuelana by its more globular chambers and prominent umbilical tooth. It postdates the extinction of " $G$." venezuelana and is frequently encountered in the Pliocene and Pleistocene of Sites 871 through 873.

\section{The Globorotalia Plexus}

Discussion. In this study, the unkeeled globorotaliids apparently related to Paragloborotalia opima are included in Paragloborotalia, and the middle Miocene lineage leading to $F$. fohsi is included in Fohsella. Several subgenera proposed for the different phylogenetic lineages within the plexus (Bandy, 1972) may ultimately prove to be reliable genera, but they are not used in this study because of continuing uncertainty about some phylogenetic relationships from the middle and late Miocene.

\section{Globorotalia archeomenardii Bolli}

(Pl. 4, Figs. 4 and 5)

Globorotalia archeomenardii Bolli, 1957, p. 119, pl. 28, figs. 11a-c

Discussion. Globorotalia archeomenardii is distinguished from Globorotalia praemenardii by its smaller size, more convex spiral side, and less lobate equatorial periphery. The form is very close to Globorotalia praescitula and is distinguished by the presence of a delicate peripheral keel. Populations in the lowermost middle Miocene apparently intergrade fully, although the forms are more distinct at higher levels. An intergradation between this form and $G$. praemenardii was observed in the middle Miocene at Site 872 .

\section{Globorotalia crassaformis (Galloway and Wissler)}

$$
\text { (Pl. 4, Fig. 17) }
$$

Globigerina crassaformis Galloway and Wissler, 1927, p. 41, pl. 7, fig. 12

Discussion. A number of morphotypes have been recognized by various authors as subspecies of $G$. crassaformis. These variants occur sporadically in the Leg 144 material, and no attempt was made to separate them.

$$
\text { Globorotalia flexuosa (Koch) }
$$

Pulvinulina tumida var. flexuosa Koch, 1923-24, p. 357, text-figs. 9 and 10

Discussion. Although Globorotalia flexuosa is regarded as a variant of $G$. tumida (less flexuose intermediates abound), the taxon is retained because it has some stratigraphic significance.

\section{Globorotalia hirsuta (d'Orbigny)}

Rotalina hirsuta d'Orbigny, 1839, p. 131, pl. 1, figs. 37-39

Discussion. Globorotalia hirsuta is a delicate form grossly similar to $G$. margaritae. However, it possesses a pustulose surface and a more concave umbilical side. It also tends to be dextrally coiled. It is rare in the Leg 144 material and occurs most frequently in the Pleistocene.
Globorotalia inflata (d'Orbigny)

Globigerina inflata d'Orbigny, 1839, p. 134, pl. 12, figs. 7-9

Discussion. Globorotalia inflata is a colder water globorotaliid that some authors place in the subgenus Globoconella. It is absent at Site 871 and occurs rarely at Sites 872 and 873 .

\section{Globorotalia limbata (Fornasini)}

Rotalia limbata Fornasini, 1902, p. 56, text-fig. 55

Discussion. Globorotalia limbata is distinguished from $G$. menardii by possessing seven to eight chambers in the final whorl. It forms an intermediate between $G$. menardii and $G$. multicamerata. It occurs most frequently in the uppermost Miocene of Sites 871 and 872, but it also occurs as high as the uppermost Pliocene at Site 873, possibly as a result of reworking.

\section{Globorotalia margaritae Bolli and Bermudez}

Globorotalia margaritae Bolli and Bermudez, 1965, p. 138, pl. 1, figs. 1-9

Discussion. Globorotalia margaritae is similar to G. hirsuta, but it is flatter and almost always sinistrally coiled. It was found in the lower Pliocene (Zone N19) at Site 873.

$$
\text { Globorotalia menardii s.l. (Parker, Jones, and Brady) }
$$

$$
\text { (Pl. 4, Fig. 13) }
$$

Rotalia menardii Parker, Jones, and Brady, 1865, p. 20, pl. 3, fig. 81

Discussion. No attempt was made to distinguish the various forms of $G$. menardii as discussed by Bolli and Saunders (1985). No direct intergradation with $G$. praemenardii was observed.

\section{Globorotalia multicamerata Cushman and Jarvis}

Globorotalia menardii (d'Orbigny) var. multicamerata Cushman and Jarvis, 1930, p. 367, pl. 34, figs. 8a-c

Discussion. Globorotalia multicamerata is a variant of the G. menardii group possessing nine or more chambers in the final whorl.

\section{Globorotalia pertenuis Beard}

$$
\text { (Pl. 4, Figs. } 14 \text { and 15) }
$$

Globorotalia pertenuis Beard, 1969, p. 552, pl. 1, figs. 1-6, and pl. 2, figs. 5 and 6

Discussion. The irregular apertural lip that partially covers the umbilicus and flat discoidal shape are considered diagnostic of this taxon. Forms with fewer than seven chambers showing affinity to $G$. exilis were not separated. Although it is very rare in the Leg 144 sediments, it may be of stratigraphic significance because it is restricted to Zone N21. It is considered a variant of G. menardii.

\section{Globorotalia plesiotumida Blow and Banner}

$$
\text { (Pl. 4, Fig. 16) }
$$

Globorotalia (Globorotalia) tumida (Brady) plesiotumida Blow and Banner, 1965, p. 1353, figs. 2a-c

Discussion. Globorotalia plesiotumida is similar in shape to G. tumida, but it is smaller and less heavily calcified. It is apparently the ancestral form to G. tumida, although no intermediates were observed in this study. Globorotalia ungulata is very close to $G$. plesiotumida and may also be descended from it (see discussion under $G$. ungulata).

\section{Globorotalia praemenardii Cushman and Stainforth}

Globorotalia praemenardii Cushman and Stainforth, p. 70, pl. 13, figs. 14a-c

Discussion. Globorotalia praemenardii is larger than G. archeomenardii with a better developed keel. It is rarer in the Leg 144 sediments (see discussion under $G$, archeomenardii).

\section{Globorotalia praescitula Blow}

$$
\text { (Pl. 4, Figs. 1-3) }
$$

Globorotalia scitula (Brady) praescitula Blow, 1959, p. 221, pl. 19, figs. $128 \mathrm{a}-\mathrm{c}$

Discussion. Globorotalia praescitula is very close to G. archeomenardii and apparently forms part of a single population in the Zone N8-N9 interval. Individuals lacking a delicate keel are placed in $G$. praescitula. 
Globorotalia scitula (Brady)

(PI. 4, Figs. 18 and 22)

Pulvinulina scitula Brady, 1882, p. 27, pl. 5, fig. 5 (lectotype)

Discussion. Globorotalia scitula occurs infrequently at Sites 871 and 872; it is present more consistently at Site 873 .

Globorotalia tosaensis Takayanagi and Saito

Globorotalia tosaensis Takayanagi and Saito, 1962, p. 81, pl. 28, figs. 11a-c

Discussion. Globorotalia tosaensis is similar to G. truncatulinoides, but it lacks an imperforate band or peripheral keel. G. tosaensis is very rare in the Leg 144 material; however, because very large samples were available, it was used for biostratigraphy at Sites 871 and 872 .

Globorotalia truncatulinoides (d'Orbigny)

(Pl. 4, Fig. 19)

Rotalia truncatulinoides d'Orbigny, 1839, p. 132, pl. 2, figs. 25-27

Discussion. Globorotalia truncatulinoides is distinguished from $G$. tosaensis by the more conical shape and the presence of a peripheral imperforate band. In the earliest $G$. truncatulinoides, the keel is very weak and the two taxa were observed to intergrade. See also comments under $G$. tosaensis.

Globorotalia tumida (Brady)

Pulvinulina menardii (d'Orbigny) var. tumida Brady, 1877, pl. 103, figs. 4-6

Discussion. Globorotalia tumida possesses an oblate outline and swollen chambers (except for the radially elongated final chamber). It is a heavily calcified form. G. tumida is similar to heavily calcified G. menardii, but it can usually be distinguished using the characters discussed by Chaisson and Leckie (1993). See also discussion under $G$. ungulata.

Globorotalia ungulata Bermudez

Globorotalia ungulata Bermudez, 1960, p. 1304, pl. 15, figs. 6a-b

Discussion. Globorotalia ungulata has a shape similar to G. tumida, and the two taxa apparently intergrade. G. ungulata has a thinner, more delicate test and is smoother. Some are less symmetrical in axial view, and sometimes it has raised umbilical shoulders to the last one or two chambers. G. ungulata may be an ecophenotype of G. tumida.

\section{Globorotaloides}

Discussion. Globorotaloides is characterized by a spire that increases in height during ontogeny. The possible link between $G$. suteri and $G$. hexagonus could not be confirmed because of the rarity of these forms. G. hexagonus apparently intergrades with Clavatorella in the uppermost lower Miocene through a morphotype similar to $C$. sturanii (see discussion under Clavatorella).

\section{Globorotaloides hexagonus (Natland)}

Globigerina hexagona Natland, 1938, p. 149, pl. 7, figs. la-c

Discussion. Globorotaloides hexagonus is a minor constituent of middle Miocene to Holocene sediments at all three sites. It is distinguished from $G$. suteri by its larger size and lobate chambers.

\section{Globorotaloides suteri Bolli}

Globorotaloides suteri Bolli, 1957, p. 117, pl. 27, figs. 15a-20c

Discussion. Globorotaloides suteri is smaller and more compact than $G$. hexagonus, and some possess an umbilical bulla.

\section{Globoturborotalita Hofker}

Discussion. This genus is probably synonymous with Zeaglobigerina Kennett and Srinivasan (1983), although a phylogenetic link between $G$. rubescens (the type species of Globoturborotalita) and the $G$. woodi group has yet to be firmly established. The Globoturborotalita group of morphotypes is characterized by a cancellate wall, which distinguishes it from the Globig. erina group. The one surviving species is $G$. rubescens. Members of the genus are typically small in size and may dominate the $<150-\mu \mathrm{m}$ size fraction. They may be difficult to distinguish from other cancellate forms such as immature Globigerinoides obliquus.
Characters of particular use in the taxonomy of the group include the size of the test, the coarseness of cancellation, the height of the spire, and the shape and size of the aperture. However, most of these features can be extremely variable in populations, and no firm lines of demarcation have been found among the plexus (except for the easily identified and stratigraphically useful species $G$. nepenthes). Therefore, in this study, only a coarse taxonomic resolution has been attempted.

\section{Globoturborotalita nepenthes (Todd)}

(PI. 5, Fig. 16)

Globigerina nepenthes Todd, 1957, p. 301, figs. 7a-b

Discussion. Globoturborotalita nepenthes is distinguished from other members of the genus by its elongate periphery and protruding, cap-like final chamber. Both its first appearance and last occurrence provide useful datums at all three sites.

\section{Globoturborotalita rubescens (Hofker)}

Globigerina rubescens Hofker, 1956, p. 234, pl. 32, fig. 26, and pl. 35, figs. $18-21$

Discussion. In this study, Globoturborotalita rubescens is distinguished from the $G$. woodi s.l. group mainly by its less compact test, small size, and circular, umbilically centered aperture. Kennett and Srinivasan (1983) record the origin of the form in the lower Pliocene. In this study, the G. rubescens morphotype was found as low as the middle Miocene, although downhole contamination is a severe problem for establishing its true stratigraphic range. Pink-pigmented individuals are common in the Pleistocene, but they have not been separated.

$$
\text { Globoturborotalita tenella (Parker) }
$$

Globigerinoides tenella, Parker, 1958, p. 280, pl. 6, figs. 7-11

Discussion. This species has been recorded as Globigerinoides by most authors. It appears to be a variant of $G$. rubescens, differing only by the possession of a single supplementary aperture. $G$. tenella is subordinate to $G$. rubescens in the Pleistocene of Sites 871 and 872 and has not been recorded from lower levels.

\section{Globoturborotalita woodi s.l. (Jenkins)}

(Pl. 1, Figs. 15 and 19)

Globigerina woodi, Jenkins 1960, p. 352, pl. 2, figs. 2a-c

Discussion. Included here are typical forms plus those that other authors place in G. brazieri, G. connecta, G. decoraperta, and G. druryi on the basis of variations in apertural shape and position.

\section{Neogloboquadrina group}

Discussion. In the Leg 144 material, the Neogloboquadrina lineage appears to be a gradual chronocline, leading from $N$. acostaensis to $N$. dutertrei.

$$
\text { Neogloboquadrina acostaensis (Blow) }
$$

Globorotalia acostaensis Blow, 1959, p. 208, pl. 17, figs. 106a-c

Discussion. Neogloboquadrina acostaensis is distinguished from $N$. humerosa by its smaller size and by the possession of five or fewer chambers in the final whorl. It is probably ancestral to Pulleniatina primalis although no intermediates were found in this study.

\section{Neogloboquadrina dutertrei (d'Orbigny)}

Globigerina dutertrei d’Orbigny, 1839, p. 84, pl. 4, figs. 19-21

Globigerina dutertrei d'Orbigny, Banner and Blow, 1960, p. 11, pl. 2, figs. la-c (lectotype)

Discussion. Neogloboquadrina dutertrei is distinguished from $N$. humerosa by its possession of an apertural flap. The earliest forms attributable to $N$. dutertrei possess a minute flap; thus, the two taxa are seen to intergrade.

$$
\text { Neogloboquadrina humerosa (Takayanagi and Saito) }
$$

Globorotalia humerosa Takayanagi and Saito, 1962, p. 78, pl. 28, figs. 1a-c

Discussion. Neogloboquadrina humerosa is distinguished from $N$. acostaensis by possessing six or more chambers in the final whorl and from 
$N$. dutertrei by lacking an apertural flap and possessing an aperture that tends toward an extraumbilical position.

\section{Orbulina}

Discussion. The origin of Orbulina by gradual transition from Globigerinoides by way of Praeorbulina is discussed under Praeorbulina. Two species of Orbulina are recognized, but they are not regarded as biologically separate: Orbulina suturalis appears a little before $O$. universa.

\section{Orbulina suturalis Brönnimann}

Orbulina suturalis Brönnimann, 1951, p. 135, figs. 2-4

Discussion. Early representatives of Orbulina suturalis (e.g., in Cores 144-871A-6H and $-7 \mathrm{H}$ ) are identical to Praeorbulina circularis except that they may possess one or more small "areal apertures" in addition to many sutural apertures. The first "areal apertures" in primitive Orbulina occur in clusters of between one and three apertures near the sutural apertures. Only in later forms do they extend all over the chamber.

\section{Orbulina universa d'Orbigny}

(Pl. 3, Fig. 17)

Orbulina universa d'Orbigny, 1839, p. 2, pl. 1, fig. 1

Discussion. Orbulina universa is distinguished from $O$. suturalis by the absence of obvious sutures with previous chambers.

?Orbulina sp.

(Pl. 3, Figs. 18-20 and 22-23)

Discussion. A single orbuline planktonic foraminifer of unknown affinities was found in Hole 873B. The wall is clearly spinose and covered with small bullae, which in turn are surrounded by slitlike sutural apertures.

\section{The Paragloborotalia Group}

Discussion. The type species of Paragloborotalia Cifelli is P. opima of the Oligocene. On the basis of supposed similarity in wall texture, Spezzaferri (1991) included the pseudokugleri-kugleri group in the genus. A close relative of $P$. opima is $P$. nana, which may have been the ancestor of $P$. continuosa and $P$. mayeri. These forms are all included in Paragloborotalia in this study although confirmation of their true relationships will probably require detailed ultrastructural studies on very well-preserved material. In this study, the presence of spine holes in any of these forms could not be confirmed (see PI. 1, Fig. 25).

\section{Paragloborotalia continuosa (Blow)}

Globorotalia opima Bolli continuosa Blow, 1959, p. 218, pl. 19, figs. 125a-c

Discussion. Small unkeeled globorotaliids occur throughout most of the lower and middle Miocene at all three sites. These have been included under the name $P$. continuosa, although it may be that several species of other authors may have been lumped together.

\section{Paragloborotalia kugleri (Bolli)}

$$
\text { (Pl. 1, Fig. 6) }
$$

Discussion. Because its disappearance defines the top of Subzone N4b, a strict definition of Paragloborotalia kugleri is desirable, particularly with reference to the possibly related form Fohsella peripheroronda, which occurs most frequently in the upper lower to middle Miocene. Bolli and Saunders (1985) considered the number of chambers in the final whorl to be of prime importance in distinguishing the two taxa. They quoted $P$. kugleri as having seven to eight chambers in the final whorl whereas $F$. peripheroronda has five to six chambers. However, Bolli (1957) quoted six to eight chambers as the variability shown by the taxon in his original description of $P$. kugleri. Many authors have illustrated forms attributed to $P$. kugleri that possess fewer than seven chambers in the final whorl (e.g., Keller, 1981; Kennett and Srinivasan, 1983; Spezzaferri, 1991).

Characters of subsidiary importance that other authors have used in distinguishing $P$. kugleri from $F$. peripheroronda are (1) the greater roundness of the equatorial periphery (Bolli and Saunders, 1985; Chaisson and Leckie, 1993), (2) less recurved spiral sutures (Kennett and Srinivasan, 1983), (3) higher aperture (Kennett and Srinivasan, 1983), (4) less recurved umbilical sutures (Keller, 1981), (5) more open umbilicus (Keller, 1981), (6) more equal-sized chambers (Kennett and Srinivasan, 1983), and (7) the lack of a flangelike lip as found in F. peripheroronda (Keller, 1981). As observed by Keller (1981) in other Pacific material, most of the above characters used to distinguish the taxa are variable across populations in the later parts of Subzone N4b. The populations contain forms with from 6 to $7 \frac{1}{2}$ chambers in the final whorl. All of these forms have been included as $P$. kugleri. A stratigraphic gap exists in the Leg 144 material between the extinction of $P$. kugleri and the appearance of true $F$. peripheroronda.

See also the discussion under $P$. pseudokugleri for a discussion of the first occurrence datum of $P$. kugleri.

$$
\text { Paragloborotalia mayeri Cushman and Ellisor }
$$$$
\text { (Pl. 1, Fig. 7) }
$$

\section{Globorotalia mayeri Cushman and Ellisor, 1939, p. 11, pl. 2, figs. 4a-c}

Discussion. Included in the synonymy with $P$. mayeri is $P$. siakensis following Bolli and Saunders (1982). Early forms in the upper Oligocene are smaller and more compact than later forms, but they are clearly distinguished from the $P$. kugleri group by their more inflated chambers and lobate profile. Early forms coil randomly and later forms are sinistrally dominant.

$$
\text { Paragloborotalia nana (Bolli) }
$$$$
\text { (PI. 1, Fig. 5) }
$$

Globorotalia opima nana Bolli, 1957, p. 118, pl. 28 figs. 3a-c

Discussion. Paragloborotalia nana is morphologically identical to $P$. opima except that it is a smaller form (up to $320 \mu \mathrm{m}$ in diameter; Bolli and Saunders, 1985). The subdivision of the two morphospecies is justified because of the restricted range and biostratigraphic utility of the larger form.

$$
\text { Paragloborotalia opima (Bolli) }
$$

Globorotalia opima opima Bolli, 1957, p. 117, pl. 28, figs. 1a-c

Discussion. See discussion under Paragloborotalia nana.

$$
\text { Paragloborotalia pseudokugleri (Blow) }
$$

Globorotalia (Turborotalia) pseudokugleri Blow, 1969, p. 391, pl. 10, figs. $4-6$, and pl. 39 , figs. 5-6

Discussion. Paragloborotalia pseudokugleri is generally smaller than $P$. kugleri, has fewer chambers in the final whorl and straight or only slightly recurved spiral sutures. The chambers are less closely appressed, and the axial periphery is rounded rather than subacute as in P. kugleri (see also Leckie et al., 1993). However, the two species fully intergrade, and the placement of the Zone P22/N4 boundary is based on the gradual transition. Note that Bolli and Saunders (1985) do not distinguish the two forms and consequently quote a considerably lower first appearance for $P$. kugleri at the base of their Globorotalia kugleri Zone.

\section{Praeorbulina Lineage}

Discussion. The full range of Praeorbulina morphospecies can be recognized in the Leg 144 material, particularly at Site 871 (see PI. 3). The evolution of the group has been discussed by many authors and appears to be a gradual transition from Globigerinoides bisphericus to Orbulina suturalis involving the expansion of the final chamber, a loss of the umbilicus, and an increase in the number of apertures around the final chamber until a full spherical morphology is attained. Some bilobed morphotypes were classified by Blow (1956) into a separate lineage leading to "Biorbulina," but these are probably ecophenotypes of Orbulina.

No objective break in the morphological continuum has been recognized, but the established morphotypes enable the accurate subdivision of the lineage and a high-resolution biostratigraphy, In this study, taxa are distinguished solely on the number and shape of the apertures around the final chamber. However, sphericity also increases during the evolution of the lineage as does the size of the final chamber relative to the rest of the test.

$$
\text { Praeorbulina circularis (Blow) }
$$$$
\text { (Pl. 3, Figs. 12-16) }
$$

Globigerinoides glomerosa circularis Blow, 1956, p. 65, text-fig. 2, nos. 3-4

Discussion. Praeorbulina circularis is the most advanced member of the genus and is distinguished from other Praeorbulina by the small circular sutural apertures. It differs from Orbulina suturalis by the absence of areal apertures. 
Praeorbulina curva (Blow)

(Pl. 3, Figs. 6, 7)

Globigerinoides glomerosa curva Blow, 1956, p. 64, text-fig. 1, nos. 9-14

Discussion. Praeorbulina curva is intermediate in morphology between $P$. sicana and $P$. glomerosa. It has more apertures around the final chamber than $P$. sicana but fewer than $P$. glomerosa.

\section{Praeorbulina glomerosa (Blow)}

(Pl. 3, Figs. 8-11)

Globigerinoides glomerosa glomerosa Blow, 1956, p. 64, text-fig. 1, nos. $15-9$, and text-fig. 2 , nos. 1-2

Discussion. Praeorbulina glomerosa is an intermediate between $P$. curva and $P$. circularis. It has numerous apertures around the base of the final chamber, which are slitlike and may form an almost continuous groove.

\section{Praeorbulina sicana (De Stefani)}

(Pl. 3, Figs. 3-5)

Globigerinoides sicanus De Stefani, 1950, p. 9, fig. 6

Discussion. Praeorbulina sicana is the earliest member of the genus. It is distinguished from Globigerinoides bisphericus by its four apertures around the base of the final chamber. The final chamber is so enveloping that there is no recognizable umbilicus.

\section{Protentella sp.}

Discussion. A few specimens referable to Protentella were found in the upper Oligocene of Site 872 (see also Premoli Silva and Spezzaferri, 1990).

\section{Pulleniatina}

Discussion. The principal Pulleniatina morphocline can be considered as running through the forms $P$. primalis, $P$. praecursor, $P$. obliquiloculata, and $P$. finalis, all of which fully intergrade and apparently constitute a single line of descent. These morphologies encapsulate a trend from small forms with regular trochospiral coiling to larger streptospiral forms with strongly reflective surfaces and apertures that extend well on to the dorsal side. This morphocline has ontogenetic, ecophenotypic, and phylogenetic components (see Bolli and Saunders, 1985). Details of the phylogeny differ from place to place, particularly between the Atlantic and Pacific provinces (see Bolli and Saunders, 1985, for review). Consequently, these changes are biostratigraphically useful on a local scale only.

The origin of the genus is from Neogloboquadrina acostaensis in the late Miocene (Kennett and Srinivasan, 1983; Chaisson and Leckie, 1993). Brönnimann and Resig (1971) have described the morphospecies P. praepulleniatina as an intermediate form. In these samples, no such intermediates are found, although this may be the result of various hiatuses.

A side branch of the line of descent found only in the Pacific province is the $P$. praespectabilis/P. spectabilis lineage. $P$. praespectabilis intergrades with $P$. primalis, but $P$. spectabilis is considered morphologically distinct.

Coiling reversals in Pulleniatina have been described by Saito (1976) and provide two important datums used in this study (see above).

\section{Pulleniatina finalis Banner and Blow}

Pulleniatina obliquiloculata (Parker and Jones) finalis Banner and Blow, 1967, p. 140, pl. 3, figs. 5a-b

Discussion. Pulleniatina finalis includes advanced members of the lineage with strongly streptospiral coiling, in which the aperture extends far on to the dorsal side, which gives the test a near symmetrical appearance. Full intergradation is observed with $P$. obliquiloculata. In the Leg 144 sites, $P$. finalis appears within Zone N22, and its first appearance is used as a biostratigraphic datum. Note, however, that its appearance is reported much earlier in other areas (Bolli and Saunders, 1985).

\section{Pulleniatina obliquiloculata (Parker and Jones)}

Pullenia sphaeroides (d'Orbigny) var. obliquiloculata Parker and Jones, 1865. p. 368 , pl. 19 , figs. $4 a-b$

Discussion. Pulleniatina obliquiloculata is distinguished from P. praecursor by its aperture, which extends to the spiral side. A full intergradation was observed with both $P$, praecursor and $P$. finalis.

\section{Pulleniatina praecursor Banner and Blow}

Pulleniatina obliquiloculata (Parker and Jones) praecursor Banner and Blow, 1967, p. 139, pl. 3, figs. 3a-c

Discussion. In Pulleniatina praecursor, the aperture extends only as far as the periphery. It forms an intermediate between Pulleniatina primalis and $P$. obliquiloculata, although it is morphologically closest to the latter.

\section{Pulleniatina praespectabilis Brönnimann and Resig}

Pulleniatina spectabilis praespectabilis Brönnimann and Resig, 1971, p. 1287 , pl. 19 , figs. 4 and 7

Discussion. Pulleniatina praespectabilis possesses an acute but wellrounded margin. It intergrades with both $P$. primalis and $P$. spectabilis. $P$. praespectabilis tends to be larger in size $(>400 \mu \mathrm{m})$ than $P$. primalis.

\section{Pulleniatina primalis Banner and Blow} (PI. 5., Fig. 1)

Pulleniatina primalis Banner and Blow, 1967, p. 142, pl. 1, figs. 3-8, and pl. 3 , figs. $2 a-c$

Discussion. Pulleniatina primalis is clearly recognizable as belonging to the genus on account of its reflective wall. Although typical $P$. primalis has five chambers in the last whorl, there are frequent forms with only four chambers in the Leg 144 material. The coiling is almost a regular trochospiral except, in some cases, for the last few chambers. The aperture is restricted to the umbilical side. P. primalis is generally smaller than later forms. However, a full intergradation exists with both $P$. praecursor and $P$. praespectabilis. The disappearance (pseudoextinction) of $P$. primalis provides a useful datum and occurs consistently a little higher than the first coiling reversal in the lineage.

\section{Pulleniatina spectabilis Parker}

(Pl. 5, Figs. 2 and 3)

Pulleniatina spectabilis, Parker, 1965, p. 151, text figs. 1-4

Discussion. Pulleniatina spectabilis includes "advanced" forms showing a pinched periphery and an almost plano-convex test. It intergrades with $P$. praespectabilis but appears to be morphologically isolated from the main Pulleniatina lineage in the highest samples. Coiling is strongly sinistrally dominated although dextral specimens were found.

\section{Sphaeroidinella and Sphaeroidinellopsis}

Discussion. The taxonomic scheme suggested by Kennett and Srinivasan (1983) was found to work well for this group in the Leg 144 sediments. With the exception of Sphaeroidinellopsis kochi, the evolution of the group is apparently a continuous chronocline from rare $S$. disjuncta in the lower Miocene to the intergrading forms Sphaeroidinella dehiscens and S. excavata in the Pleistocene. Sphaeroidinellopsis kochi apparently became morphologically isolated from the main lineage in about Zone N9.

\section{Sphaeroidinella dehiscens (Parker and Jones)}

(Pl. 5, Fig. 9)

Sphaeroidina bulloides d'Orbigny var. dehiscens Parker and Jones, 1865, p. 369 , pl. 19 , fig. 5

Discussion. Forms possessing supplementary apertures but not the very open test of $S$. excavata are included in this taxon. The earliest representatives are extreme variants of the Sphaeroidinellopsis paenedehiscens population but possess minute supplementary apertures.

\section{Sphaeroidinella excavata Banner and Blow}

(Pl. 5, Fig. 10)

Sphaeroidinella dehiscens (Parr and Jones) excavata Banner and Blow, 1965, p. 1164; holotype illustrated in Banner and Blow, 1967, pl. 4, fig. 5

Discussion. Sphaeroidinella excavata is regarded as a variant of S. dehiscens. It is distinguished by the extremely large supplementary apertures and open test morphology. It is regarded as the most "advanced" member of the lineage. S. excavata is most common in the upper part of Zone N22, but it also occurs as low as Zone N21 at Site 873. 
Sphaeroidinellopsis disjuncta (Finlay)

Sphaeroidinella disjuncta Finlay, 1940, p. 467, pl. 67, figs. 224-228

Discussion. Sphaeroidinellopsis disjuncta is similar to $S$. seminulina, but it possesses a poorly developed cortex. It is rare in the Leg 144 sediments, but it was found in Zones N8 and N9 at Site 872.

\section{Sphaeroidinellopsis kochi (Caudri)}

(PI. 5, Figs. 8, 22, and 23)

Globigerina kochi Caudri, 1934, text-figs. 8a-b

Discussion. Sphaeroidinellopsis kochi is distinguished from other species of Sphaeroidinellopsis by its lower trochospire, more radially elongate chambers that may vary considerably in number, and less well-defined cortex. Specimens with a weak cortex show extremely coarse cancellation and spine holes. S. kochi apparently intergrades with $S$. seminulina toward the bottom of its range, but it is morphologically isolated at higher levels. At Site 871, S. kochi occurs only sporadically. It appears more consistently at Sites 872 and 873 and its disappearance (at the top of Zone N20) is potentially a useful datum (see also Chaisson and Leckie, 1993).

\section{Sphaeroidinellopsis paenedehiscens Blow}

Sphaeroidinellopsis paenedehiscens Blow, 1969, p. 386, pl. 30, figs. 4-5 and 9

Discussion. Sphaeroidinellopsis paenedehiscens is distinguished from $S$. seminulina by its more compact shape and embracing chambers and from Sphaeroidinella dehiscens by lacking a supplementary aperture.

Sphaeroidinellpsis seminulina (Schwager)

Globigerina seminulina Schwager, 1886, p. 256, pl. 7, fig. 112

Discussion. Sphaeroidinellopsis seminulina is distinguished from S. compacta by its more complete cortex and from $S$. paenedehiscens by its more lobate periphery.

\section{Streptochilus spp.}

Discussion. No attempt has been made to distinguish morphospecies within this biserial genus in the construction of the range chart (detailed SEM analysis would be required). At Site 871, Streptochilus is present continuously from Subzone N17a to within Zone N22. At Site 872, Streptochilus was found only from the middle of Zone N20 to the lower part of Zone N22. At Site 873, Streptochilus is present continuously from the surface (which is mid-Zone N22) down to the unconformity that truncates Zone N18.

\section{Subbotina}

Discussion. Members of the high-spired Subbotina gortanii lineage are found sporadically in Zone P22 of Hole 872C.

\section{Subbotina praeturritilina (Blow and Banner)}

Globigerina turritilina praeturritilina Blow and Banner, pl. XIII, figs. A-C

Discussion. Low-spired variants of $S$. gortanii are included in this taxon.

$$
\text { Subbotina gortanii (Borsetti) }
$$$$
\text { (PI. 1, Fig. 4) }
$$

Catapsydrax gortanii Borsetti, 1959, pp. 205-207, figs. la-d

Discussion. This is a high-spired subbotinid related to $S$. praeturritilina. Typical of this form is the reduced final chamber in an umbilical position.

\section{Tenuitella and Tenuitellinata}

Discussion. Small microperforate planktonic foraminifers are common in the Oligocene to the lower Miocene and in the Pleistocene of sediments from Leg 144. Much work has been done in recent years on the taxonomy of these forms (e.g., $\mathrm{Li}, 1987$; $\mathrm{Li}$ et al., 1992). In the absence of other characters, chamber number, the position and shape of the aperture, and coiling arrangement are of prime importance in their taxonomy. These characters show great variability in populations. However, broad trends in the evolution of these forms are apparent.

$$
\text { Tenuitella clemenciae (Bermudez) }
$$

$$
\text { (Pl. 1, Fig. 16) }
$$

Globorotalia clemenciae Bermudez, p. 1321, pl. 17, fig. 10

Discussion. Tenuitella clemenciae possesses four rapidly expanding chambers in the final whorl and an umbilical-extraumbilical aperture. It is distinguished from Tenuitella munda by its less inflated chambers. T. clemenciae is the dominant tenuitellid in the lower to middle Miocene of Sites 871 and 872 . Scattered five-chambered forms close to Tenuitellinata angustiumbilicata that occur in the lower Miocene were included.

$$
\text { Tenuitella gemma (Jenkins) }
$$

Globorotalia gemma Jenkins, 1965, p. 1115, fig. 11, nos. 97-103

Discussion. Tenuitella gemma typically has five chambers in the final whorl, a low trochospiral, and an umbilical/extraumbilical aperture. This taxon apparently intergrades with both Tenuitella munda and Tenuitellinata angustiumbilicata. It occurs sporadically in the upper Oligocene and lower Miocene of Site 872.

\section{Tenuitella iota (Parker)}

(Pl. 5, Figs. 18, 19)

Globigerinita iota Parker, p. 250, pl, 10, figs. 26-30

Discussion. This form is a low-spired tenuitellid that is frequent in Pleistocene sediments at Sites 871,872 , and 873 . The last whorl typically possesses $4 \frac{1}{2}$ to 5 chambers. An umbilical bulla was sometimes observed, similar to Globigerinita glutinata. Considerable variability is shown in the degree of compression and elongation of the chambers. Specimens typically possess conical pustules on the ventral side. Some morphotypes that were included as T. iota may belong to other species, but the taxonomy of the group is uncertain.

$$
\text { Tenuitella munda (Jenkins) }
$$

Globorotalia munda Jenkins, p. 1121, fig. 14, nos. 126-133

Discussion. Tenuitella munda possesses four rapidly expanding and inflated chambers in the final whorl and an umbilical/extraumbilical aperture. It is consistently present in Zone P22 of Hole 872C. Sporadic higher occurrences may be reworked.

$$
\text { Tenuitella sp. }
$$

$$
\text { (PI. 1, Figs. } 23 \text { and 24) }
$$

Discussion. Recorded as Tenuitella sp. are large, thin-walled tenuitellids typically possessing five chambers in the final whorl and a prominent umbilical tooth. They occur in the lower to middle Miocene of Sites 871, 872, and 873. These forms show considerable morphological variability. In some specimens, the final one or two chambers are anterior-posteriorly flattened. The aperture in others is typically a narrow crescentic slit. Some specimens show similar slitlike sutural supplementary apertures on the spiral side. Others appear to be almost planispirally coiled in the last whorl. Several unidentified species may have been included in this taxon.

$$
\text { Tenuitellinata angustiumbilicata (Bolli) }
$$

$$
\text { (Pl. 1, Fig. 17) }
$$

Globigerina ciperoensis angustiumbilicata Bolli, 1957, p. 109, pl. 22, figs. 12 and 13

Discussion. Bolli (1957) originally described this form as a subspecies of Globigerina ciperoensis. However, the wall texture is smooth and microperforate, as discussed by $\mathrm{Li}$ (1987). Most specimens possess five chambers in the final whorl. The aperture is in an umbilical position and possesses a lip. T. angustiumbilicata is consistently present in the upper Oligocene and lowermost Miocene at Site 872, but it is more sporadic at Site 871.

\section{Turborotalita humilis (Brady)}

$$
\text { (Pl. 5, Fig. 20) }
$$

Truncatulina humilis Brady, 1884, p. 36, pl. 8, fig. 1 (lectotype)

Discussion. A broad morphological concept is taken for this species and includes the Turborotalita cristata morphotype (see Hemleben et al., 1989). T. humilis is common in the Pleistocene of Leg 144 sediments and was not found below Zone N20.

\section{ACKNOWLEDGMENTS}

Special thanks to Isabella Premoli Silva, Elisabetta Erba, Dave Watkins, and the other Leg 144 paleontologists for an enjoyable and stimulating time in the paleontology laboratory. Dick Kroon kindly schooled me in aspects of Neogene taxonomy before the cruise, for 
which I am very grateful. Mark Leckie, Isabella Premoli Silva, Silvia Spezzaferri, and an anonymous reviewer made many useful comments on the manuscript.

\section{REFERENCES}

Bandy, O.L., 1972. Origin and development of Globorotalia (Turborotalia) pachyderma (Ehrenberg). Micropaleontology, 18:294-318.

Berggren, W.A., Kent, D.V., and Flynn, J.J., 1985a. Jurassic to Paleogene: Part 2. Paleogene geochronology and chronostratigraphy. In Snelling, N.J. (Ed.), The Chronology of the Geological Record. Geol. Soc. London Mem., 10:141-195.

Berggren, W.A., Kent, D.V., and Van Couvering, J.A., 1985b. The Neogene: Part 2. Neogene geochronology and chronostratigraphy. In Snelling, N.J. (Ed.), The Chronology of the Geological Record. Geol. Soc. London Mem., 10:211-260.

Berggren, W.A., and Miller, K.G., 1988. Paleogene tropical planktonic foraminiferal biostratigraphy and magnetobiochronology. Micropaleontology, $34: 362-380$.

Blow, W.H., 1956. Origin and evolution of the foraminiferal genus Orbulina d'Orbigny. Micropaleontology, 2:57-70.

_ 1969. Late middle Eocene to Recent planktonic foraminiferal biostratigraphy. In Brönniman, P., and Renz, H.H. (Eds.), Proc. First Int. Conf. Planktonic Microfossils, Geneva, 1967: Leiden (E.J. Brill), 1:199-422.

Blow, W.H., and Banner, F.T., 1966. The morphology, taxonomy and biostratigraphy of Globorotalia barisanensis LeRoy, Globorotalia fohsi Cushman and Ellisor, and related taxa. Micropaleontology, 12:286-302.

Bolli, H.M., 1957. Planktonic foraminifera from the Oligocene-Miocene Cipero and Lengua formations of Trinidad, B.W.I. In Loeblich, A.R., Jr., Tappan, H., Beckmann, J.P., Bolli, H.M., Gallitelli, E.M., and Troelsen, J.C. (Eds.), Studies in Foraminifera. Bull.-U.S. Nat. Mus., 215:97-124.

Bolli, H.M., and Saunders, J.B., 1982. Globorotalia mayeri and its relationship to Globorotalia siakensis and Globorotalia continuosa. J. Foraminiferal Res., 12:39-50.

-1985 . Oligocene to Holocene low latitude planktonic foraminifera. In Bolli, H.M., Saunders, J.B., and Perch-Nielsen, K. (Eds.), Plankton Stratigraphy: Cambridge (Cambridge Univ. Press), 155-262.

Brönnimann, P., and Resig, J., 1971. A Neogene globigerinacean biochronologic time-scale of the Southwestern Pacific. In Winterer, E.L., Riedel, W.R., et al., Init. Repts. DSDP, 7, Pt. 2: Washington (U.S. Govt. Printing Office), 1235-1469.

Chaisson, W.P., and Leckie, R.M., 1993. High-resolution Neogene planktonic foraminifer biostratigraphy of Site 806, Ontong Java Plateau (western equatorial Pacific). In Berger, W.H., Kroenke, L.W., Mayer, L.A., et al., Proc. ODP, Sci. Results, 130: College Station, TX (Ocean Drilling Program), 137-178.

Cushman, J.A., and Stainforth, R.M., 1945. The foraminifera of the Cipero Marl Formation of Trinidad, British West Indies. Specl Publ.-Cushman Lab., 14:1-75.

Davis, A.S., Pringle, M.S., Pickthorn, L.B.G., Clague, D.A., and Schwab, W.C., 1989. Petrology and age of alkalic lava from the Ratak Chain of the Marshall Islands. J. Geophys. Res., 94:5757-5774.

Fordham, B.G., 1986. Miocene-Pleistocene planktic foraminifers from DSDP Sites 208 and 77, and phylogeny and classification of Cenozoic species. Evolutionary Monogr., 6:1-200.

Genin, A., Dayton, P.K., Lonsdale, P.F., and Speiss, F.N., 1986. Corals on seamount peaks provide evidence of current acceleration over deep-sea topography. Nature, 322:59-61.

Haq, B.U., Hardenbol, J., and Vail, P.R., 1987. Chronology of fluctuating sea levels since the Triassic. Science, 235:1156-1167.

Hein, J.R., Kang, J.K., et al., 1990. Geological, geochemical, geophysical, and oceanographic data and interpretations of seamounts and C-rich ferromanganese crusts from the Marshall Islands, KORDI-USGS R.V. Faranella cruise F10-89-CP. Open-File Rep.-U.S. Geol. Surv., 90-407.

Hemleben, C., Spindler, M., and Anderson, O.R., 1989. Modern Planktonic Foraminifera: Berlin (Springer-Verlag).

Jenkins, D.G., and Orr, W.N., 1972. Planktonic foraminiferal biostratigraphy of the eastern equatorial Pacific-DSDP Leg 9. In Hays, J.D., et al., Init. Repts. DSDP, 9: Washington (U.S. Govt. Printing Office), 1059-1193.

\footnotetext{
- Abbreviations for names of organizations and publications in ODP reference lists follow the style given in Chemical Abstracts Service Source Index (published by American Chemical Society).
}

Jenkins, D.G., Saunders, J.B., and Cifelli, R., 1981. The relationship of Globigerinoides bisphericus Todd 1954 to Praeorbulina sicana (de Stefani) 1952. J. Foraminiferal Res., 11:262-267.

Keller, G., 1980. Early to middle Miocene planktonic foraminiferal datum levels of the equatorial and subtropical Pacific. Micropaleontology, 26:372-391.

,1981. The genus Globorotalia in the early Miocene of the equatorial and northwestern Pacific. J. Foraminiferal Res., 11:118-132.

Kennett, J.P., Keller, G., and Srinivasan, M.S., 1985. Miocene planktonic foraminiferal biogeography and paleoceanographic development of the Indo-Pacific region. In Kennett, J.P. (Ed.), The Miocene Ocean: Paleoceanography and Biogeography. Mem.-Geol. Soc. Am., 163:197-236.

Kennett, J.P., and Srinivasan, M.S., 1983. Neogene Planktonic Foraminifera: A Phylogenetic Atlas: Stroudsburg, PA (Hutchinson Ross).

Leckie, R.M., Farnham, C., and Schmidt, M.G., 1993. Oligocene planktonic foraminifer biostratigraphy of Hole 803D (Ontong Java Plateau) and Hole 628A (Little Bahama Bank), and comparison with the southern high latitudes. In Berger, W.H., Kroenke, L.W., Mayer, L.A., et al., Proc. ODP, Sci. Results, 130: College Station, TX (Ocean Drilling Program), 113-136.

Li, Q., 1987. Origin, phylogenetic development and systematic taxonomy of the Tenuitella plexus (Globigerinitidae, Globigerinina). J. Foraminiferal Res., 17:298-320.

Li, Q., Radford, S.S., and Banner, F.T., 1992. Distribution of microperforate tenuitellid planktonic foraminifers in Holes 747A and 749B, Kerguelen Plateau. In Wise, S.W., Jr., Schlich, R., et al., Proc. ODP, Sci. Results, 120: College Station, TX (Ocean Drilling Program), 569-594.

Lonsdale, P., 1977. Abyssal bedforms explored with a deeply towed instrument package. Mar. Geol., 23:57-75.

Lonsdale, P., and Malfait, B., 1974. Abyssal dunes of foraminiferal sand on the Carnegie Ridge. Geol. Soc. Am. Bull., 85:1697-1712.

Lonsdale, P., Normark, W.R., and Newman, W.A., 1972. Sedimentation and erosion on Horizon Guyot. Geol. Soc. Am. Bull., 83:289-315.

Melillo, Allan J., 1988. Neogene planktonic foraminifer biostratigraphy, ODP Leg 101, Bahamas. In Austin, J.A., Jr., Schlager, W., et al., Proc. ODP, Sci. Results, 101: College Station, TX (Ocean Drilling Program), 3-45.

Parker, F.L., 1967. Late Tertiary biostratigraphy (planktonic foraminifera) of tropical Indo-Pacific deep-sea cores. Bull. Am. Paleontol., 52:111-208.

Parsons, B., and Sclater, J.G., 1977. An analysis of the variation of ocean floor bathymetry and heat flow with age. J. Geophys. Res., 82:803-829.

Pearson, P.N., 1992. Survivorship analysis of fossil taxa when extinction rates vary: the Paleogene planktonic foraminifera. Paleobiology, 18:115-131. , 1993. A lineage phylogeny for the Paleogene planktonic foraminifera. Micropaleontology, 39:193-232.

Premoli Silva, I., Haggerty, J., Rack, F., et al., 1993. Proc. ODP, Init. Repts., 144: College Station, TX (Ocean Drilling Program).

Premoli Silva, I., and Spezzaferri, S., 1990. Paleogene planktonic foraminifer biostratigraphy and paleoenvironmental remarks on Paleogene sediments from Indian Ocean sites, Leg 115. In Duncan, R.A., Backman, J., Peterson, L.C., et al., Proc. ODP, Sci. Results, 115: College Station, TX (Ocean Drilling Program), 277-314.

Pringle, M.S., 1992. Geochronology and petrology of the Musicians Seamounts, and the search for hot spot volcanism in the Cretaceous Pacific [Ph.D. dissert.]. Univ. of Hawaii, Honolulu.

Saito, T., 1976. Geologic significance of coiling direction in the planktonic foraminifer Pulleniatina. Geology, 4:305-309.

Spezzaferri, S., 1991. Evolution and taxonomy of the Paragloborotalia kugleri (Bolli) lineage. J. Foraminiferal Res., 21:313-318.

Spezzaferri, S., and Premoli Silva, I., 1991. Oligocene planktonic foraminiferal biostratigraphy and paleoclimatic interpretation from Hole $538 \mathrm{~A}$, DSDP Leg 77, Gulf of Mexico. Palaeogeogr., Palaeoclimatol., Palaeoecol., 83:217-263.

Srinivasan, M.S., and Kennett, J.P., 1983. The Oligocene-Miocene boundary in the South Pacific. Geol. Soc. Am. Bull., 94:789-812.

Stein, C.A., and Stein, S., 1992. A model for the global variation in oceanic depth and heat flow with lithospheric age. Nature, 359:123-129.

Ujiié, H., 1975. Planktonic foraminiferal biostratigraphy in the western Philippine Sea, Leg 31 of DSDP. In Karig, D.E., Ingle, J.C., Jr., et al., Init. Repts. DSDP, 31: Washington (U.S. Govt. Printing Office), 677-691.
Date of initial receipt: 25 January 1994

Date of acceptance: 28 July 1994

Ms 144SR-013 


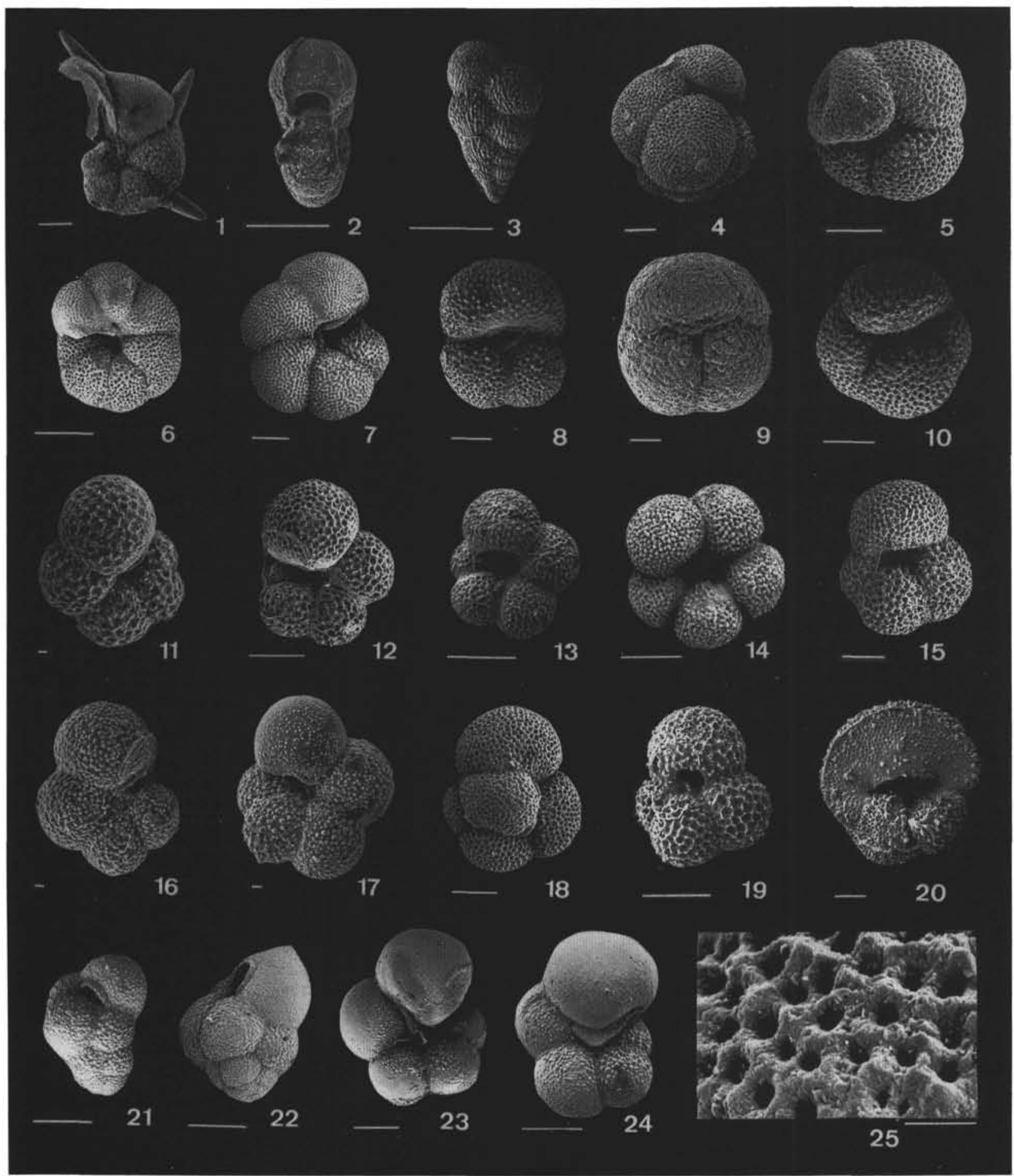

Plate 1. Various planktonic foraminifers. 1. Hantkenina alabamensis, Sample 144-872C-15H-6, 20-22 cm (reworked). 2. Pseudohastigerina micra, Sample 144-872C-17X-2, 20-22 cm (reworked). 3. Chiloguembelina cubensis, Sample 144-872C-16H-CC (reworked). 4. Subbotina praeturritilina, Sample 144$872 \mathrm{C}-16 \mathrm{H}-6,20-22 \mathrm{~cm}$. 5. Paragloborotalia nana, Sample 144-872C-16H-6, 20-22 cm. 6. Paragloborotalia kugleri, Sample 144-871A-13H-4, 58-60 cm. 7. Globorotalia mayeri, Sample 144-871A-4H-4, 59-61 cm. 8. Globoquadrina tripartita, Sample 144-872C-17X-1, 20-22 cm. 9. Globoquadrina tripartita, Sample 144-872C-15H-5, 20-22 cm. 10. "Globoquadrina" venezuelana, Sample 144-872C-16H-CC. 11, 12. "Globigerina" cf. ciperoensis, Sample 144-872C$16 \mathrm{H}-6,20-22 \mathrm{~cm}$. 13. "Globigerina" angulisuturalis, Sample 144-872C-17X-1, 20-22 cm. 14. "Globigerina" angulisuturalis, Sample 144-872C-16H-2, 20-22 cm. 15. Globoturborotalita woodi s.l., Sample 144-872C-16H-6, 20-22 cm. 16. Tenuitella clemenciae, Sample 144-872C-16H-6, 20-22 cm. 17. Tenuitellinata angustiumbilicata, Sample 144-872C-16H-6, 20-22 cm. 18. Catapsydrax unicavus, Sample 144-872C-15H-5, 20-22 cm. 19. Globoturborotalita woodi s.l., showing homeomorphy with G. rubescens, Sample 144-872C-14H-6, 20-22 cm. 20. Globoquadrina binaiensis, Sample 144-871A-15H-3, 59-61 cm. 21. Globigerinita uvula, Sample 144-871A-13H-CC. 22. Globigerinita uvula, with "sacculiferid" chamber, Sample 144-871A-14H-2, 60-62 cm. 23. Tenuitella sp. Note umbilical toothplate, Sample 144-873B-5H-6, 36-38 cm. 24. Tenuitella sp. Sample 144-873B-6H-2, 36-38 cm. 25. Paragloborotalia kugleri, wall texture (same specimen as Fig. 6). Scale bars are $100 \mu \mathrm{m}$, except for Figures 11, 16-21, and 25, which have scale bars that are $10 \mu \mathrm{m}$. 


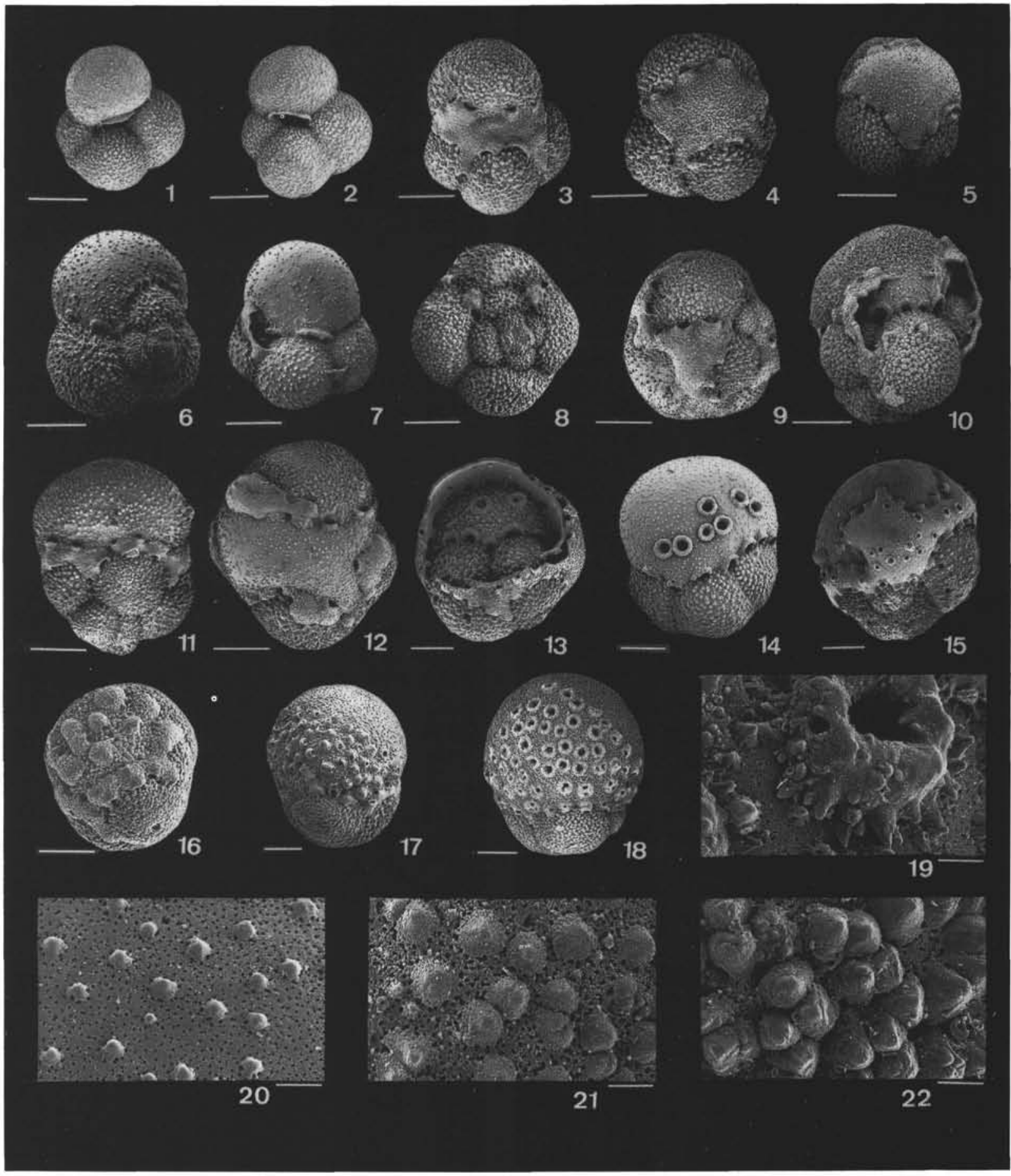

Plate 2. The Globigerinita glutinata-Globigerinatella insueta lineage. 1-4. Globigerinita glutinata, Sample 144-871A-12H-6, 58-60 cm. 5. Globigerinita glutinata with swollen bulla, showing transition to Globigerinatella sp., Sample 144-871A-12H-5, 59-61 cm. 6. Globigerinita glutinata, showing inflated bulla/final chamber transitional to Globigerinatella sp., Sample 144-871A-10H-4,59-61 cm. 7. Globigerinatella sp., Sample 144-871A-12H-5, 58-60 cm. Note broken secondary bullae. 8. Globigerinatella sp., Sample 144-871A-12H-5, 58-60 cm. Spiral view. Note secondary bullae. 9. Globigerinatella sp., Sample 144-871A-12H-6, 58-60 cm. 10. Globigerinatella sp. Note secondary bullae, Sample 144-871A-12H-5, 59-61 cm. 11, 12. Globigerinatella sp., Sample 144-871A-12H-4, 58-60 cm. 13. Globigerinatella insueta s.str. Note areal apertures on final (broken) chamber and previous chamber, Sample 144-873B-5H-4, $36-38 \mathrm{~cm}$. 14. Globigerinatella insueta s.str., Sample 144-873B-4H-3,36-38 cm. 15. Globigerinatella insueta s.str., Sample 144-873B-4H-3,36-38 cm. 16. Globigerinatella insueta s.str., showing areal bullae covering apertures, Sample 144-873B-7H-5, 124-126 cm. 17. Globigerinatella insueta s.str., showing areal bullae each with a secondary areal aperture, Sample 144-873B-7H-5,59-61 cm. 18. Globigerinatella insueta s.str. Note sharply delineated zone of areal apertures, typical of advanced specimens, Sample 144-873B-5H-4,36-38 cm. 19. Globigerinatella insueta s.str., wall texture. Note stellate pustules and small secondary areal aperture around apertural neck (specimen not illustrated, same specimen as Fig. 22). 20, 21. Globigerinatella insueta s.str., wall texture. Note microperforate wall with pyramidal pustules (same specimen as Fig. 14). 22. Globigerinatella insueta s.str., wall texture. Note heavily calcified pustules (specimen not illustrated). Scale bars are $100 \mu \mathrm{m}$, except for Figures 19-22, which have scale bars that are $10 \mu \mathrm{m}$. 


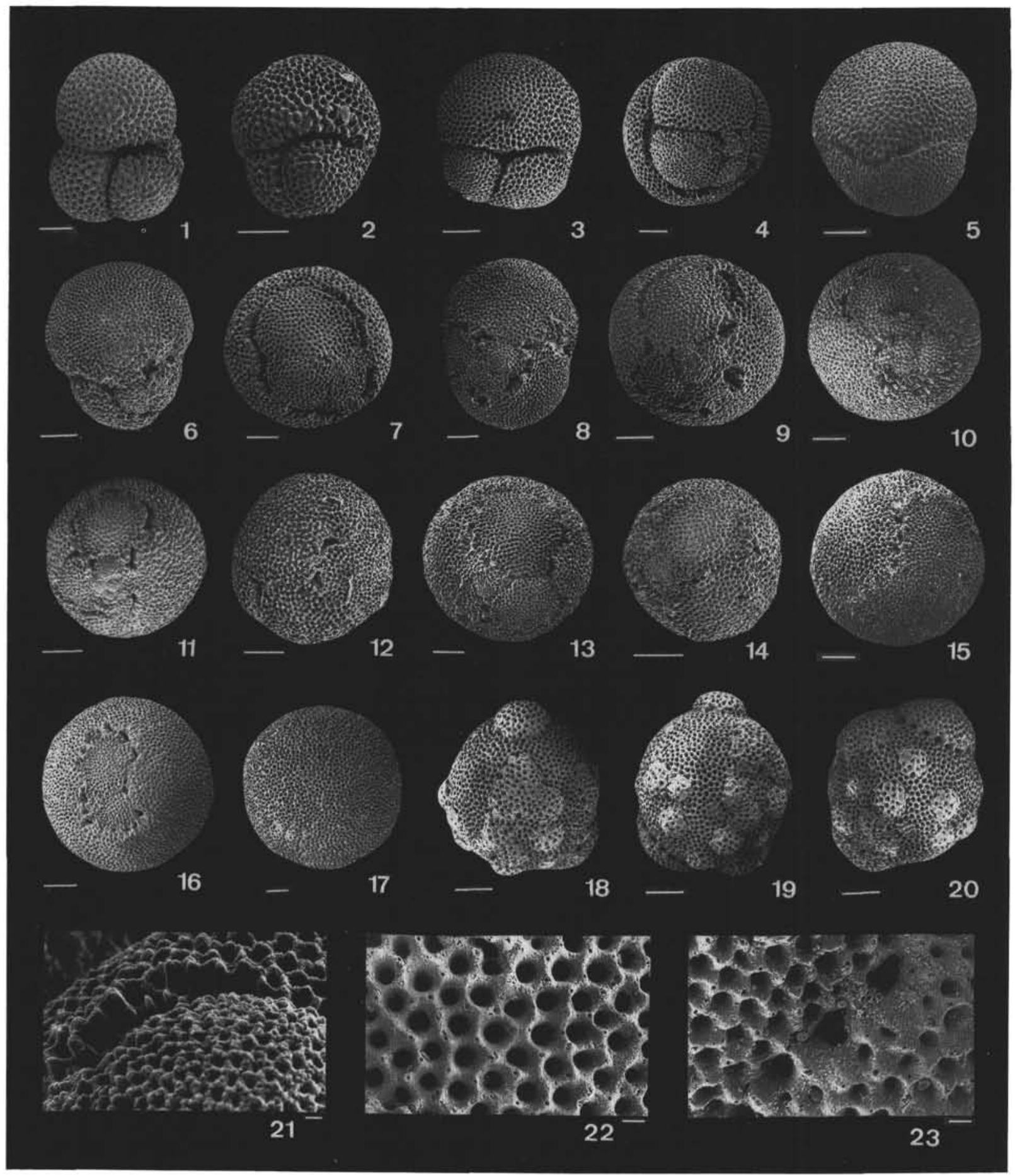

Plate 3. The Praeorbulina-Orbulina lineage. 1. Globigerinoides trilobus s.1., Sample 144-871A-7H-CC. 2. Globigerinoides bisphericus, Sample 144871A-7H-CC. 3, 4. Praeorbulina sicana (two views of same specimen), Sample 144-871A-7H-CC. 5. Praeorbulina sicana, Sample 144-871A-7H-CC. 6. Praeorbulina curva, Sample 144-871A-7H-CC. 7. Praeorbulina curva, Sample 144-871A-7H-CC. 8. Praeorbulina glomerosa, showing bispherical morphology, Sample 144-871A-7H-CC. 9-11. Praeorbulina glomerosa-circularis transitional specimens, Sample 144-871A-7H-CC. 12-16. Praeorbulina circularis, Samples 144-871A-7H-CC. 17. Orbulina universa, Sample 144-872C-1H-2, 58-60 cm. 18-20. Orbulina? sp. Three views of same specimen, showing spherical morphology and numerous bullae, Sample 144-873B-5H-2, 36-38 cm. 21. Wall structure of Praeorbulina sicana (same specimen as Fig. 4), showing additional thickness of final chamber. 22. Wall structure of Orbulina? sp. (same specimen as Figs. 18-20), showing cancellate structure and spine holes. 23. Detail of Orbulina? sp. (same specimen as Figs. 18-20), showing apertures around bullae. Scale bars are $100 \mu \mathrm{m}$, except for Figures 11, 16, and 21-23, which have scale bars that are $10 \mu \mathrm{m}$. 


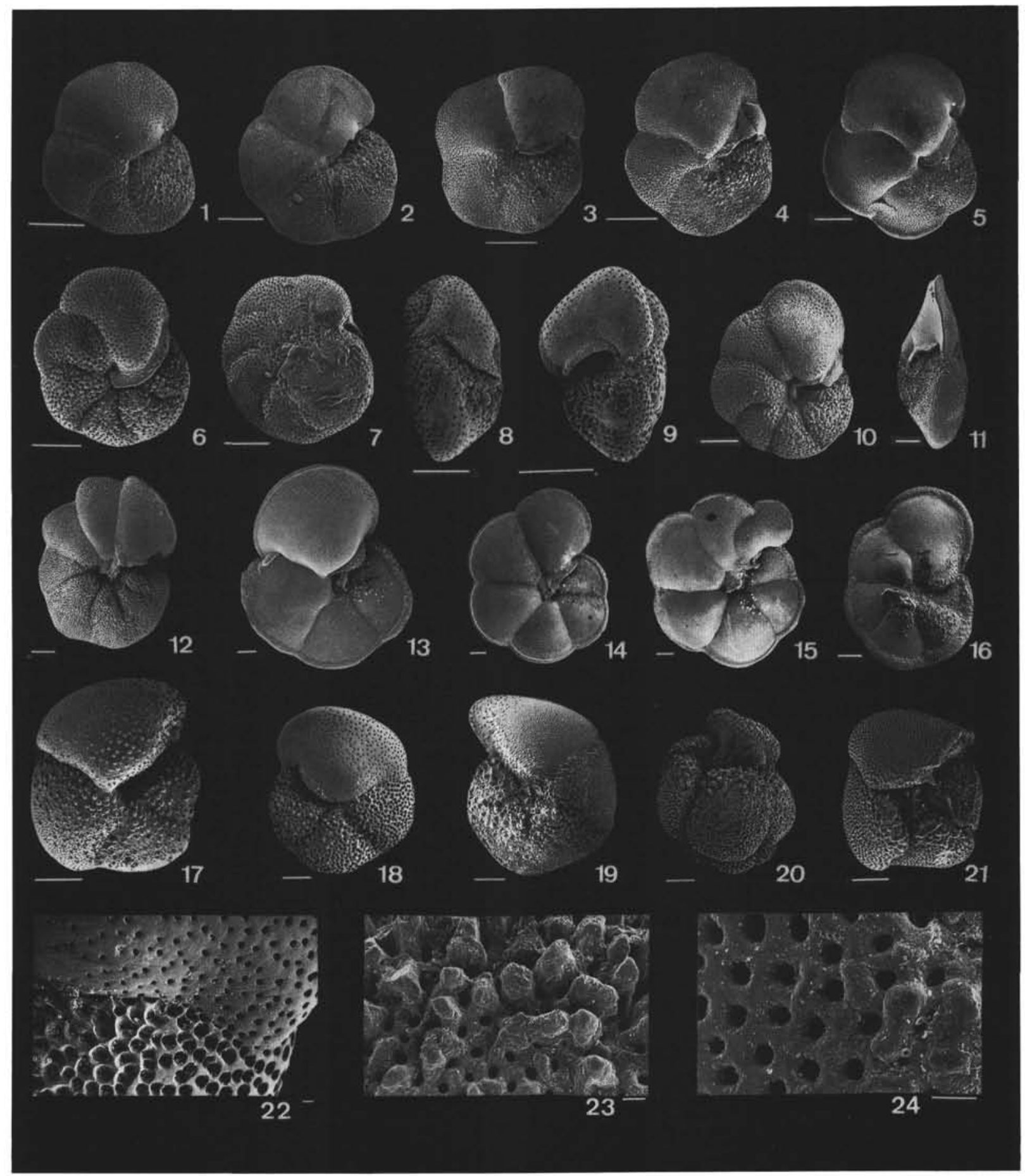

Plate 4. Various planktonic foraminifers. 1-3. Globorotalia praescitula, Sample 144-871A-7H-5, 59-61 cm. 4. Globorotalia archeomenardii, Sample 144871A-7H-CC. 5. Globorotalia archeomenardii, Sample 144-871A-7H-CC. 6-8. Fohsella peripheroronda, Sample 144-871A-7H-CC. 9. Fohsella peripheroronda peripheroacuta transition, Sample 144-871A-7H-CC. 10. Fohsella peripheroacuta, Sample 144-873B-6H-2,36-38 cm. 11. Fohsellafohsi, side view, Sample 144-871A-4H-5, 59-61 cm. 12. Fohsella lobata, Sample 144-871A-4H-5, 59-61 cm. 13. Globorotalia menardii, Sample 144-873B-1H-CC. 14. Globorotalia pertenuis, transitional to G. exilis, Sample 144-871A-3H-3, 125-127 cm. 15. Globorotalia pertenuis, Sample 144-871A-3H-3, 125-127 cm. 16 . Globorotalia plesiotumida, Sample 144-871A-3H-4, 60-62 cm. 17. Globorotalia crassaformis, Sample 144-873B-1H-CC. 18. Globorotalia scitula, Sample 144-873B-1H-CC. 19. Globorotalia truncatulinoides, Sample 144-872C-1H-2, 58-60 cm. 20. "Dentoglobigerina" altispira, Sample 144-871A-7H-CC. 21. Globoquadrina dehiscens, Sample 144-871A-7H-CC. 22. Wall texture of Globorotalia scitula (same specimen as Fig. 18). Note sunken pores on penultimate chamber. 23. Wall texture of "Dentoglobigerina" altispira (same specimen as Fig. 20). No spine holes were found. 24. Wall texture of Globoquadrina dehiscens (same specimen as Fig. 21), similar to wall of "D." altispira. Scale bars are $100 \mu \mathrm{m}$, except for Figures 22-24, which have scale bars that are $10 \mu \mathrm{m}$. 


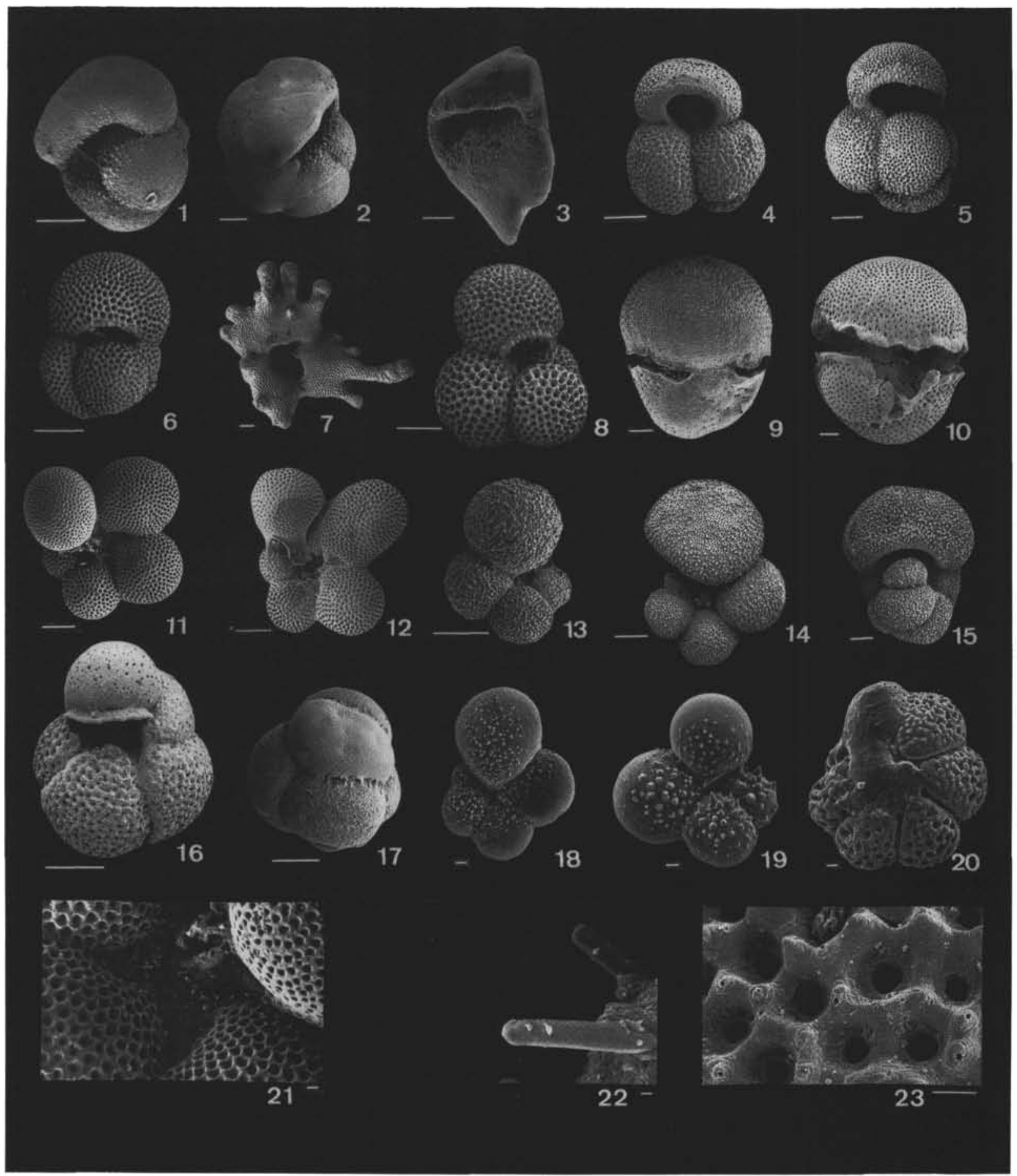

Plate 5. Various planktonic foraminifers. 1. Pulleniatina primalis, Sample 144-873B-4H-3, 36-38 cm. 2. Pulleniatina spectabilis, Sample 144-873B-3H-3, $36-38 \mathrm{~cm}$. 3. Pulleniatina spectabilis, Sample 144-873B-3H-3, 36-38 cm. 4. Globigerinoides ruber s.1. (G. subquadratus of some authors), Sample 144-871A-7H-CC. 5. Globigerinoides mitra, Sample 144-871A-9H-4, 59-61 cm. 6. Globigerinoides trilobus s.l., Sample 144-871A-4H-4, 59-61 cm. 7. Globigerinoides fistulosus, Sample 144-871A-3H2,123-125cm. 8. Sphaeroidinellopsis kochi, atypical specimen with few chambers and no cortical overgrowth, Sample 144-873B-4H-3, 36-38 cm. 9. Sphaeroidinella dehiscens, Sample 144-872C-1H-2, 58-60 cm. 10. Sphaeroidinella excavata, Sample 144-873B-1HCC. 11. Clavatorella bermudezi, showing features transitional to Globorotaloides hexagonus, Sample 144-871A-7H-5,59-61 cm. 12. Clavatorella bermudezi, Sample 144-871A-7H-5, 124-126 cm. 13. Globigerinella praesiphonifera, Sample 144-871A-7H-5, 124-126 cm. 14. Globigerinella siphonifera, Sample $144-871$ A-4H-4, 59-61 cm. 15. Globigerinella siphonifera, Sample 144-872C-1H-2, 58-60 cm. 16. Globoturborotalita nepenthes, Sample 144-873B-3H-4, $36-38 \mathrm{~cm}$. 17. Candeina nitida, Sample $144-873 \mathrm{~B}-1 \mathrm{H}-4,36-38 \mathrm{~cm} . \quad \mathbf{1 8}, \mathbf{1 9}$. Tenuitella iota. Note conical pustules, Sample $144-872 \mathrm{C}-1 \mathrm{H}-2,58-60 \mathrm{~cm} . \quad 20$. Turborotalita humilis, Sample 144-872C-1H-2, 58-60 cm. 21. Clavatorella bemudezi (same specimen as Fig. 11), magnification of umbilical region, showing umbilical plate formed by fusion of apertural flanges. 22. Sphaeroidinellopsis kochi (same sample as Fig. 8), showing spines preserved in aperture. 23. Sphaeroidinellopsis kochi (same sample as Fig. 8), showing cancellate spinose wall. Scale bars are $100 \mu \mathrm{m}$, except for Figures 18-21 and 23, which have scale bars that are $10 \mu \mathrm{m}$, and Figure 22, which has a scale bar that is $1 \mu \mathrm{m}$. 